\title{
Rhodium and Iridium Complexes with a New Scorpionate Phosphane Ligand
}

Angel L. Serrano, Miguel A. Casado, * José A. López, and Cristina Tejel*

Instituto de Síntesis Química y Catálisis Homogénea (ISQCH),

CSIC - Universidad de Zaragoza, Departamento de Química Inorgánica, Pedro Cerbuna 12, 50009-Zaragoza (Spain)

Dedicated to Prof. Dr. Antonio Laguna on the occasion of his $65^{\text {th }}$ birthday 
Abstract. A straightforward synthesis of a new hybrid scorpionate ligand $\left[(\text { allyl })_{2} \mathrm{~B}\left(\mathrm{CH}_{2} \mathrm{PPh}_{2}\right)(\mathrm{Pz})\right]^{-}\left(\left[\mathrm{A}_{2} \mathrm{BPN}\right]^{-}\right)$is reported. Coordination to rhodium resulted in squareplanar complexes $\left[\mathrm{Rh}\left(\kappa^{2}-\mathrm{A}_{2} \mathrm{BPN}\right)(\mathrm{L})\left(\mathrm{L}^{\prime}\right)\right]\left(\mathrm{L}=\mathrm{L}^{\prime}=1 / 2 \operatorname{cod}(1,5\right.$-cyclooctadiene $), \mathrm{CN}^{t} \mathrm{Bu}, \mathrm{CO}(\mathbf{6})$; $\mathrm{L}=\mathrm{CO}, \mathrm{L}^{\prime}=\mathrm{NH}_{3}$, pyridine, $\mathrm{PPh}_{3}, \mathrm{PMe}_{3}$ ) for which spectroscopic data and the molecular structure of $\left[\mathrm{Rh}\left(\kappa^{2}-\mathrm{A}_{2} \mathrm{BPN}\right)(\mathrm{CO}) \mathrm{PPh}_{3}\right](\mathbf{1 1})$ indicate the ligand to be $\kappa N, \kappa P$-bound to rhodium with two dangling free allyl groups. Studies in solution point out that the six-membered Rh-N-N-B-C-P metallacycle undergoes a fast inversion in all of them. The bis(carbonyl) complex 6 easily loses a $\mathrm{CO}$ group to give $\left[\left\{\mathrm{Rh}\left(\mathrm{A}_{2} \mathrm{BPN}\right)(\mathrm{CO})\right\}_{2}\right]$, a dinuclear compound in which two mononuclear subunits are brought together by two bridging allyl groups. Coordination to iridium is dominated by a tripodal $\kappa N, \kappa P, \eta^{2}-C=C$ binding mode in the $T B P Y-5$ complexes $\left[\operatorname{Ir}\left(\kappa^{3}-\mathrm{A}_{2} \mathrm{BPN}\right)(\mathrm{L})\left(\mathrm{L}^{\prime}\right)\right]\left(\mathrm{L}=\mathrm{L}^{\prime}=1 / 2 \operatorname{cod}(\mathbf{3}), \mathrm{CN}^{t} \mathrm{Bu}(\mathbf{5}), \mathrm{CO}(\mathbf{7}) ; \mathrm{L}=\mathrm{CO}, \mathrm{L}^{\prime}=\mathrm{PPh}_{3}\right.$ (13), $\mathrm{PMe}_{3}$ (14), $\mathrm{H}_{2} \mathrm{C}=\mathrm{CH}_{2},(\mathbf{1 7}), \mathrm{MeO}_{2} \mathrm{CC} \equiv \mathrm{CCO}_{2} \mathrm{Me}(\mathrm{dmad}, \mathbf{1 8})$ ), as confirmed by the singlecrystal structure determination of complexes 3 and 18. A fast exchange between the two allyl arms is observed for complexes having $\mathrm{L}=\mathrm{L}^{\prime}(\mathbf{3}, \mathbf{5}$, and $\mathbf{7})$, while those having $\mathrm{CO}$ and $\mathrm{L}$ ligands $(14,17$ and 18) were found to be non-fluxional species. An exception is complex 13, which establishes an equilibrium with the $S P-4$ configuration. Protonation reactions on complexes $\mathbf{1 3}$ and 14 with $\mathrm{HCl}$ yielded the hydride-complex $\left[\operatorname{Ir}\left(\kappa^{2}-\mathrm{A}_{2} \mathrm{BPN}\right)(\mathrm{CO})(\mathrm{Cl})(\mathrm{H}) \mathrm{PPh}_{3}\right](\mathbf{1 5})$ and the $C$ alkyl compound [Ir $\left\{\kappa^{3}-(\right.$ allyl $\left.\left.) \mathrm{B}\left(\mathrm{CH}_{2} \mathrm{CHCH}_{3}\right)\left(\mathrm{CH}_{2} \mathrm{PPh}_{2}\right)(\mathrm{Pz})\right\}(\mathrm{Cl})(\mathrm{CO}) \mathrm{PMe}_{3}\right]$ (16), respectively. The bis(isocyanide) complex 5 reacts with dmad to form $\left[\operatorname{Ir}\left(\kappa^{2}-\mathrm{A}_{2} \mathrm{BPN}\right)\left(\mathrm{CN}^{t} \mathrm{Bu}\right)_{2}(\mathrm{dmad})\right]$. On the whole, the electronic density provided to the metal by the $\left[\mathrm{A}_{2} \mathrm{BPN}\right]^{-}$ligand is very sensitive to 
the coordination mode. The basicity of the new ligand is similar to that of the $\mathrm{Tp}^{\mathrm{Me} 2}$ ligand in the $\kappa N, \kappa P$ mode, but comparable to Tp if coordinated in the $\kappa N, \kappa P, \eta^{2}-C=C$ mode.

\section{Introduction}

Ligand design has become a major concept in organometallic chemistry, a chemical tool developed to tailor the stability and/or chemical reactivity of transition metal complexes. From a certain perspective, the ligand architecture (described by the disposition of the donor atoms) mainly defines the geometry around a transition metal center in a metal complex, while the ligand nature (associated to the donor groups) allows for control over electronic and steric properties. A conjunction of both properties will eventually impact on the reactivity of their complexes. Consequently, an exceptional effort has been dedicated to design ligand scaffolds specifically to stabilize metallic fragments in a pre-defined geometry. In this context, a special mention is required for pincer ligands, ${ }^{1}$ in which the meridional coordination results in strong binding to the metal allowing outstanding examples of $\mathrm{C}-\mathrm{H}$ bond activation. ${ }^{2}$

Unlike the aforementioned pincer ligands, the ubiquitous poly(pyrazolyl)borate (Tp or scorpionate) provides three nitrogen atoms that cap one face of a coordination polyhedron. ${ }^{3}$ These versatile ligands have attracted an enormous interest in distinct fields of science for a long time, ranging from bioinorganic chemistry to materials science, and applications in organometallic and coordination chemistry are very well documented. ${ }^{4}$ The broad body of work generated by these Tp-based complexes encouraged new adaptations and improvements of the architectures of the scorpionate ligands, mainly by varying alkyl or aryl substituents at the 3 and/or 5 positions of the pyrazolyl rings (' $2^{\text {nd }}$ generation'), ${ }^{5}$ The structural variations on these ligands allowed tailoring their cone and wedge angles, influencing the metal basicity by changing the nature of the pyrazolyl substituents, giving rise to a new set of late transition metal 
complexes able to perform unusual metallorganic transformations. ${ }^{6}$ Moreover, structural adjustments by functionalizing the fourth site at boron (' $3^{\text {rd }}$ generation') ${ }^{7}$ has provided interesting examples of original oligotopic ligands to be used as scaffolds for oligonuclear complexes, ${ }^{8}$ and to covalently anchor RhTp-based systems peripherally to carbosilane dendrimers in specific cases. $^{9}$

While the catalytic properties of these N-based tripodal systems is being unfolded within the last years, ${ }^{10}$ the curiosity of scientists together with the desire for fine-tuning electronic parameters in tripodal assemblies led naturally to the development of non-pyrazolyl, anionic borate-based ligands of the type $\left[\mathrm{RBD}_{3}\right]^{-}{ }^{11}$ These new constructs are potentially $C_{3}$-symmetric face-capping ligands, which bear donor groups $\mathrm{D}$ based on atoms other than $\mathrm{N}$ (e.g. $\mathrm{P},{ }^{12} \mathrm{~S},{ }^{13}$ and $\mathrm{C}^{14}$ ) providing different electronic environments to the metals, which has made possible the observation of unusual reactivity patterns. ${ }^{12 \mathrm{~d}, 15}$

With the idea of bringing together mixed donor sets ' $\mathrm{N}_{2} \mathrm{P}$ ', we reported the synthesis ${ }^{16}$ of the hybrid, anionic scorpionate-like ligand $\left[\left(\mathrm{CH}_{2}=\mathrm{CHCH}_{2}\right) \mathrm{B}\left(\mathrm{CH}_{2} \mathrm{PPh}_{2}\right)(\mathrm{Pz})_{2}\right]^{-}(\mathrm{Pz}=$ pyrazolate $)$, while Peters and co-workers ${ }^{17}$ documented the related ' $\mathrm{P}_{2} \mathrm{~N}$ ' hybrid system $\left[\mathrm{PhB}\left(\mathrm{CH}_{2} \mathrm{P}^{t} \mathrm{Bu}_{2}\right)_{2}(\mathrm{Pz})\right]^{-}$. Aimed by the rich reactivity and coordination chemistry displayed by the iridium complexes stabilized by the ' $\mathrm{PN}_{2}$ ' tripodal system, which showed the allyl arm not to be innocent, ${ }^{18}$ we decided to take a step further in the design of such hybrid architectures and now we wish to report the synthesis of a new ligand with a flexible scaffold, provided with a set of three different donors based on hard $(\mathrm{N})$ and soft $(\mathrm{P}, \mathrm{C})$ atoms of composition $\left[(\text { allyl })_{2} \mathrm{~B}\left(\mathrm{CH}_{2} \mathrm{PPh}_{2}\right)(\mathrm{Pz})\right]^{-}\left(\left[\mathrm{A}_{2} \mathrm{BPN}\right]^{-}\right)$, as well as the coordination chemistry and reactivity shown by its rhodium and iridium complexes. 


\section{Results and Discussion}

The new ligand $\left[(\text { allyl })_{2} \mathrm{~B}\left(\mathrm{CH}_{2} \mathrm{PPh}_{2}\right)(\mathrm{Pz})\right]^{-}\left(\left[\mathrm{A}_{2} \mathrm{BPN}\right]^{-}\right)$features a central boron atom connected to two allyl groups, one pyrazolyl ring and a pendant $\mathrm{CH}_{2} \mathrm{PPh}_{2}$ moiety. It is a new anionic scorpionate if one considers that the allylic groups may coordinate to metals in a $\eta^{2}-C=C$ fashion. ${ }^{18}$ The ligand brings together hard $\mathrm{N}$-donor and soft $\mathrm{P}$ - and $\mathrm{C}$-donor groups, which makes the study of its coordination chemistry to transition metals very attractive, since it can accommodate metallic fragments in different ways. The ligand has been synthesized as the $[\operatorname{Li}($ tmen $)]\left[\mathrm{A}_{2} \mathrm{BPN}\right]$ salt $([\operatorname{Li}($ tmen $)][1])$ in two steps as shown in Scheme 1: i) formation of the intermediate $\left[(\text { allyl })_{3} \mathrm{~B}\left(\mathrm{CH}_{2} \mathrm{PPh}_{2}\right)\right]^{-}$by treatment of $\mathrm{B}(\text { allyl })_{3}$ with an equimolar amount of $\left.[\mathrm{Li}(\mathrm{tmen})]\left[\mathrm{CH}_{2} \mathrm{PPh}_{2}\right]\right)$; ii) protonation of one of the allyl arms with pyrazole. This approach represents a convenient way to this type of system since propene is the only waste in the second step. Tetra-substitution of the boron atom in $\left[\mathrm{A}_{2} \mathrm{BPN}\right]^{-}$was confirmed by the shift of the signal at $\delta-5.89$ ppm, in the ${ }^{11} \mathrm{~B}\left\{{ }^{1} \mathrm{H}\right\}$ NMR spectrum. ${ }^{19}$ A broad resonance at $\delta-13.6 \mathrm{ppm}$ in the ${ }^{31} \mathrm{P}\left\{{ }^{1} \mathrm{H}\right\}$ NMR spectrum indicated the lithium ion to be coordinated to phosphorous, while the expected resonances for the equivalent allyl arms and the pyrazolyl group were observed in the ${ }^{1} \mathrm{H}$ NMR spectrum.

Scheme 1. Synthesis of compound [Li(tmen)][1].

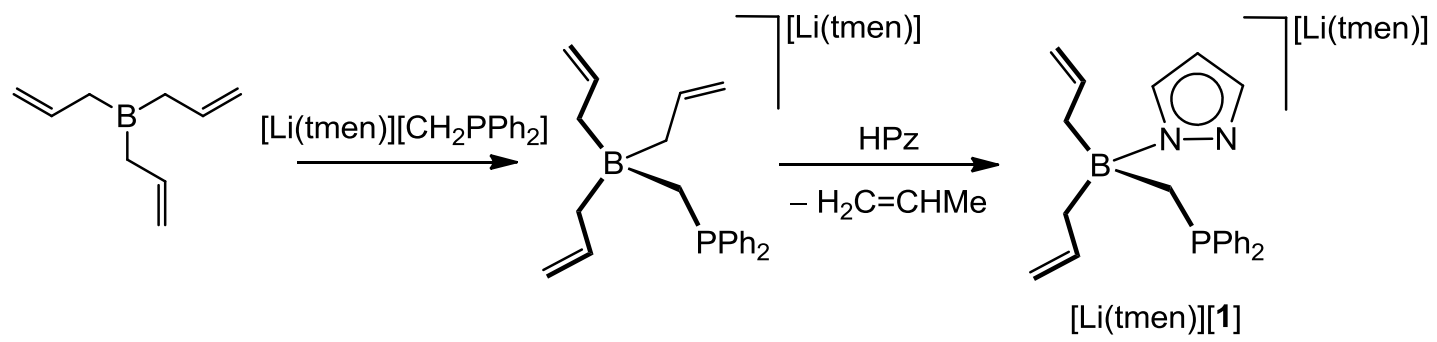


Coordination of the ' $\mathrm{M}(\mathrm{cod}))^{\natural}(\mathrm{M}=\mathrm{Rh}, \mathrm{Ir})$ fragments to $\mathbf{1}$ was achieved by reaction of $[\mathrm{Li}(\mathrm{tmen})]\left[\mathrm{A}_{2} \mathrm{BPN}\right]$ with the complexes $\left[\{\mathrm{M}(\mu-\mathrm{Cl})(\operatorname{cod})\}_{2}\right]$, which rendered the compounds $\left[\mathrm{M}\left(\mathrm{A}_{2} \mathrm{BPN}\right)(\operatorname{cod})\right](\mathrm{M}=\mathrm{Rh}, \mathbf{2} ; \mathrm{Ir}, \mathbf{3} ; \operatorname{cod}=1,5$-cyclooctadiene $)$ as yellow and white solids, respectively, in good yields. Nonetheless, complex $\mathbf{3}$ was prepared in better yield starting from $[\operatorname{Ir}(\operatorname{acac})(\operatorname{cod})](\mathrm{acac}=$ acetylacetonate) $($ Scheme 2, phenyl groups on the $\mathrm{P}$ atom have been omitted for clarity in all schemes and charts).

Scheme 2. Synthesis of complexes 2 and 3. $\mathrm{i}=\left[\{\mathrm{Rh}(\mu-\mathrm{Cl})(\operatorname{cod})\}_{2}\right], \mathrm{ii}=[\operatorname{Ir}(\mathrm{acac})(\operatorname{cod})]$.

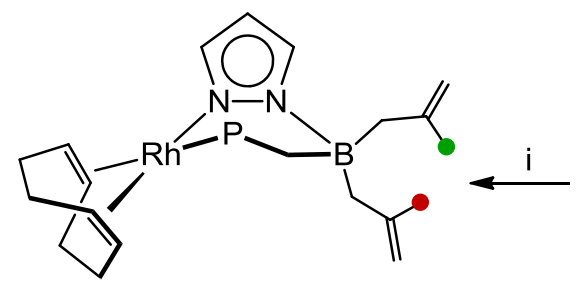

2

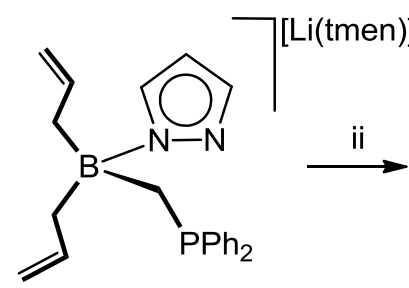

[Li(tmen)][1]

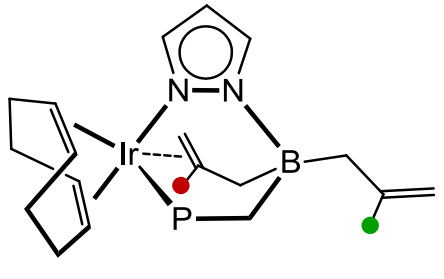

3

Both complexes were found to be fluxional and the frozen structures, shown in Scheme 2, were observed on cooling. At $-80{ }^{\circ} \mathrm{C}$, both exhibited four resonances for the olefinic-cod protons and inequivalent allyl groups in the ${ }^{1} \mathrm{H}$ NMR spectra, a clear indication of the lack of symmetry of the complexes. Moreover, the $=\mathrm{CH}$ protons from the allyl groups (marked with red and green circles in Scheme 2) were found as broad signals at $\delta 6.81$ and $6.05 \mathrm{ppm}$ for the rhodium complex $\mathbf{2}$, i.e., in the typical region for non-coordinated olefins. Therefore, both allyl groups are free in $\mathbf{2}$ and the ligand binds the rhodium through the $\mathrm{P}$ and $\mathrm{N}$ ends to produce the puckered structure (Scheme 2) at low temperature. On the contrary, these resonances were found to be at $\delta$ 6.45 and $3.60 \mathrm{ppm}$ for the iridium counterpart (3). The shift to high-field of one of them (as well as for the corresponding $=\mathrm{CH}_{2}$ protons, observed at $\delta 3.92$ and $2.10 \mathrm{ppm}$ ) agree with the bonding 
of one of the allyl groups to iridium, which was confirmed by a single crystal X-ray analysis of complex 3 (see below). Consequently, the frozen structure for complex 3 corresponds to a pentacoordinated compound with the tripodal ligand coordinated in a $\kappa \mathrm{N}, \kappa \mathrm{P}, \eta^{2}-\mathrm{C}=\mathrm{C}$ fashion.

On raising the temperature, the allyl groups coalesce in both cases, emerging as an unique allyl group above room temperature. For the rhodium complex 2, the set of signals was found at chemical shifts typical for free allyl ligands, so that an easy inversion of the six-membered metallacycle $(\overparen{R h-N-N-B-C-P})$ accounts for the experimental data (Scheme 3). This inversion has to occur through the planar $C_{S}$-conformation, which presents a steric hindrance between the olefinic-cod protons and the $\mathrm{H}^{3}$ proton from the pyrazolyl and the phenyl groups on the phosphorus. Consequently, this process should be facilitated by less demanding ligands on the metal centre, as shown below for the bis(carbonyl) and bis(isocyanide) derivatives.

Scheme 3. Fluxional motion undergone by complex 2.

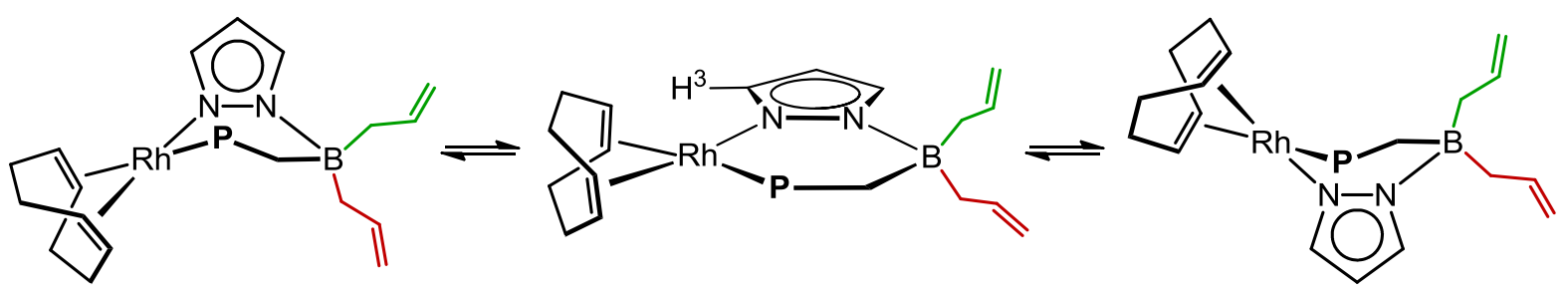

On the contrary, the allyl groups of the iridium counterpart $\mathbf{3}$ emerge from the coalescence as a set of signals of the $\mathrm{CH}_{2}=\mathrm{CH}$ - moiety still shifted to high field (see Supporting Information). The equivalence of both allyl groups and the modification of chemical shifts can easily be interpreted as an equilibrium between two species, $\mathbf{A}$ and $\mathbf{B}$ (Scheme 4), resulting from decoordination of the allyl group followed by an easy boat-to-boat inversion of the square-planar 
species and re-coordination of the other allyl group (Scheme 4). This dynamic process is reminiscent with that generally shown by Tp-complexes, ${ }^{5 \mathrm{~d}, 20}$ based upon sequential coordinationdecoordination steps of the pyrazolyl moieties. However, the dangling groups in the present case are the allylic fragments, while the pyrazolyl and phosphane arms remain coordinated throughout the dynamic process. Accordingly, no appreciable changes in the chemical shifts of the protons of the pyrazolyl group were observed in the VT- ${ }^{1} \mathrm{H}$ NMR spectra and the chemical shift of the phosphorus remained almost unaltered in the same range of temperature.

Scheme 4. Proposed motions justifying the fluxional behavior of complex 3.

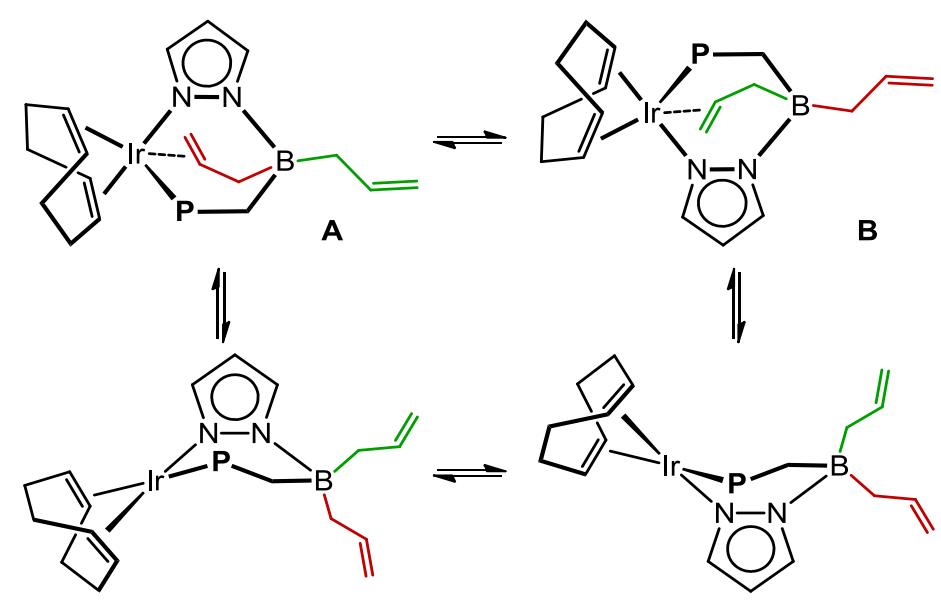

The molecular structure of $\mathbf{3}$ together with the atom labeling scheme used is shown in Figure 1, while Table 1 displays selected bond distances and angles. In the complex, the iridium atom lies at the center of a slightly distorted trigonal bipyramid $(T B P Y-5)$ coordinated to the scorpionate ligand in a $\kappa N, \kappa P, \eta^{2}-C=C$ fashion and to the $\mathrm{C}=\mathrm{C}$ bonds of cod in the typical chelating mode. 


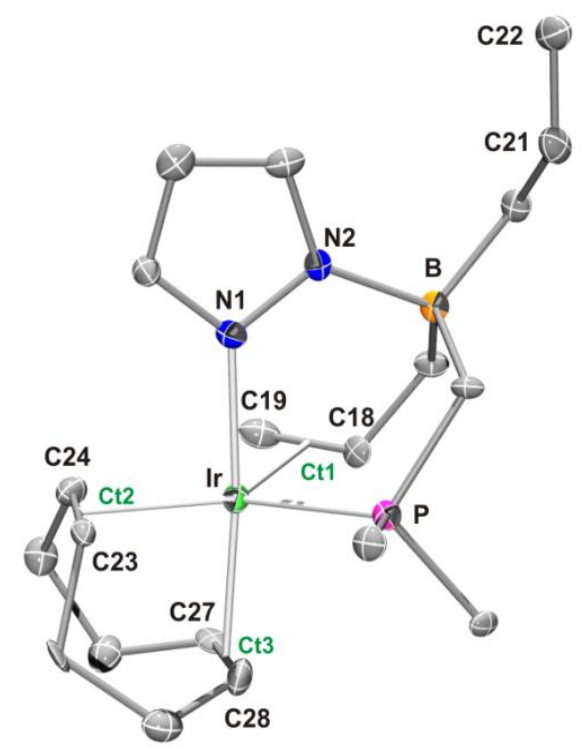

Figure 1. Molecular structure (ORTEP at $50 \%$ level) of complex $\left[\operatorname{Ir}\left(\kappa^{3}-\mathrm{A}_{2} \mathrm{BPN}\right)(\operatorname{cod})\right](3)$. Hydrogen atoms and solvent of crystallization have been removed and only the ipso carbon atoms of the phenyl groups are shown for clarity.

Table 1. Selected bond distances $(\AA)$ and angles $\left(^{\circ}\right)$ for complex $\mathbf{3}$.

\begin{tabular}{llll}
\hline $\mathrm{Ir}-\mathrm{P}$ & $2.384(2)$ & $\mathrm{N} 1-\mathrm{Ir}-\mathrm{Ct} 3$ & $174.1(2)$ \\
$\mathrm{Ir}-\mathrm{N} 1$ & $2.114(5)$ & $\mathrm{Ct} 1-\mathrm{Ir}-\mathrm{Ct} 2$ & $126.7(2)$ \\
$\mathrm{Ir}-\mathrm{Ct} 1$ & $2.143(6)$ & $\mathrm{P}-\mathrm{Ir}-\mathrm{Ct} 1$ & $101.3(2)$ \\
$\mathrm{Ir}-\mathrm{Ct} 2$ & $2.034(6)$ & $\mathrm{P}-\mathrm{Ir}-\mathrm{Ct} 2$ & $131.4(2)$ \\
$\mathrm{Ir}-\mathrm{Ct} 3$ & $2.095(6)$ & $\mathrm{N} 1-\mathrm{Ir}-\mathrm{Ct} 1$ & $86.4(2)$ \\
$\mathrm{C} 18-\mathrm{C} 19$ & $1.385(8)$ & $\mathrm{N} 1-\mathrm{Ir}-\mathrm{Ct} 2$ & $90.12(2)$ \\
$\mathrm{C} 21-\mathrm{C} 22$ & $1.345(9)$ & $\mathrm{N} 1-\mathrm{Ir}-\mathrm{P}$ & $85.1(1)$ \\
$\mathrm{C} 23-\mathrm{C} 24$ & $1.442(9)$ & $\mathrm{P}-\mathrm{Ir}-\mathrm{Ct} 3$ & $97.2(2)$ \\
$\mathrm{C} 27-\mathrm{C} 28$ & $1.403(9)$ & & \\
\hline
\end{tabular}

$\mathrm{Ct} 1, \mathrm{Ct} 2$, and $\mathrm{Ct} 3$ represent the middle points of the $\mathrm{C} 18-\mathrm{C} 19, \mathrm{C} 23-\mathrm{C} 24$, and $\mathrm{C} 27-\mathrm{C} 28$ bonds, respectively. 
The axial positions are occupied by the N1 atom of the pyrazolyl ring and one olefinic bond $(\mathrm{C} 27-\mathrm{C} 28)$ of cod, while the $\mathrm{P}$ atom, the $\eta^{2}-\mathrm{C}=\mathrm{C}$ bond of one allyl group and the other olefinic bond of cod (C23-C24) lay at the equatorial sites. All the equatorial angles are different from each other and from $120^{\circ}$, being the $\mathrm{P}-\mathrm{Ir}-\mathrm{Ct} 1$ angle the smallest $\left(101.3(2)^{\circ}\right)$, probably forced by the rigidity of the coordinate tripodal framework. The $\mathrm{C}=\mathrm{C}$ bond distance of the cod ligand occupying the equatorial site $(1.442(9) \AA)$ is longer than that for the $\mathrm{C}=\mathrm{C}$ bond at the axial site (1.403(9) $\AA$ ), as expected from a stronger $\pi$-back donation from the metal in the equatorial plane. For the coordinated allyl group, this $\mathrm{C}=\mathrm{C}$ bond distance was even shorter $(1.385(8) \AA)$ and close to that in the free allyl group (1.345(9) $\AA$ ), suggesting it to be a labile ligand. Noticeably, the $\eta^{2}$ allyl group was found to be bonded to iridium in a very asymmetric way, as reflected by the $\mathrm{Ir}-$ C18 and Ir-C19 distances of 2.301(6) and 2.202(6) $\AA$, respectively. On the whole, these distances are similar to those found in other $\eta^{2}$-olefin iridium complexes such as $\left[\operatorname{Ir}(\mathrm{Tpm})(\mathrm{H})\left(\mathrm{CH}=\mathrm{CH}_{2}\right)\left(\mathrm{C}_{2} \mathrm{H}_{4}\right)\right] \mathrm{PF}_{6}(\mathrm{Tpm}=\operatorname{tris}(3,5$-dimethylpyrazolyl)methane $)(2.171(10)$ and $2.142(11) \quad \AA),{ }^{21} \quad\left[\operatorname{IrCl}\left(\mathrm{L}_{\mathrm{Fe}}\right)(\operatorname{cod})\right]\left[\mathrm{PF}_{6}\right] \quad\left(\mathrm{L}_{\mathrm{Fe}} \quad=\quad\left[\mathrm{Fe}\left(\eta^{5}-\mathrm{C}_{5} \mathrm{H}_{5}\right)\left\{\eta^{6}-1,1-\operatorname{di}(2-\right.\right.\right.$ propenyl $)-3-$ butenyl $\}$ benzene $] \quad(2.191(6) \quad$ and $2.319(6) \quad \AA),{ }^{22}$ and $\quad\left[\operatorname{Ir}\left\{(\mathrm{Pz}) \mathrm{B}\left(\eta^{2}-\right.\right.\right.$ allyl $\left.\left.)\left(\mathrm{CH}_{2} \mathrm{PPh}_{2}\right)(\mathrm{Pz})\right\}(\mathrm{CO}) \mathrm{PMe}_{3}\right](2.227(4)$ and $2.168(5) \AA) .{ }^{18}$

Related isocyanide and carbonyl complexes of formula $\left[\mathrm{M}\left(\mathrm{A}_{2} \mathrm{BPN}\right)(\mathrm{L})_{2}\right]\left(\mathrm{L}=\mathrm{CN}^{t} \mathrm{Bu}, \mathrm{M}=\mathrm{Rh}\right.$, 4; Ir, 5; L = CO, M = Rh, 6; Ir, 7) were easily prepared by reacting complexes $\mathbf{2}$ and $\mathbf{3}$ with $\mathrm{CN}^{t} \mathrm{Bu}$ in a 1:2 molar ratio, and by bubbling carbon monoxide through solutions of $\mathbf{2}$ and $\mathbf{3}$. The bis(isocyanide) complexes $\mathbf{4}$ and $\mathbf{5}$ were stable enough to be isolated as yellow and white solids, respectively. However, the bis(carbonyl) derivatives $\mathbf{6}$ and 7 were maintained as such only under an atmosphere of carbon monoxide and, consequently, they were characterized in situ. In fact, evaporation of the solvent was associated to the loss of one carbonyl ligand from the rhodium 
complex (to give the dimer $\left[\left\{\mathrm{Rh}\left(\mathrm{A}_{2} \mathrm{BPN}\right)(\mathrm{CO})\right\}_{2}\right](\mathbf{8})$, see below) and a full decomposition for the iridium compound.

Complexes 4-7 retain the original stereochemistry of their cod precursors $(\mathbf{2}, 3)$, which depends on the metal: while rhodium tends to adopt square-planar geometries, iridium prefers TBPY-5 environments facilitated by the $\eta^{2}-\mathrm{C}=\mathrm{C}$ coordination of one allyl group. Accordingly, equivalent free allyl groups were observed in the ${ }^{1} \mathrm{H}$ NMR of the rhodium complexes (4 and $\mathbf{6}$ ) at room temperature, as commented above for $\left[\mathrm{Rh}\left(\kappa^{2}-\mathrm{A}_{2} \mathrm{BPN}\right)(\mathrm{cod})\right]$ (2) (See Experimental Section). On cooling, no changes in the spectra were observed, which indicates a lower energy barrier for the inversion of the metallacycle than for the cod complexes. This lower barrier can be expected from the lesser steric requirements of the isocyanide and carbonyl ligands relative to cod, which lead to less hindered planar conformations, as observed in related dinuclear puckered structures. ${ }^{23}$ In addition, two intense bands at 2159 and $2114 \mathrm{~cm}^{-1}$, assigned to the symmetric and antisymmetric stretches of the isocyanide ligands, were observed in the IR spectrum of 4 . These frequencies compare well with those shown by $\left[\mathrm{Rh}\left(\mathrm{Tp}^{\mathrm{Me} 2}\right)(\mathrm{CNR})_{2}\right](\mathrm{R}=$ neopentyl, xylyl, Me), in which a $\kappa^{2} N$ coordination of the $\mathrm{Tp}^{\mathrm{Me} 2}$ ligand was confirmed both in solution and in the solid state. ${ }^{24}$ However, the nature of complex 4 differs drastically from that of the Tp complex $\left[\{\operatorname{RhTp}\}_{2}(\mu-\mathrm{CNCy})_{3}\right]$, which is stabilized by three isocyanide bridging moieties. ${ }^{25}$

On the other hand, variable temperature NMR spectra of the iridium counterparts (5 and 7) indicated both to be penta-coordinated species at low temperature, but undergo a fast allylexchange at room temperature. As a way of example, Figure 2 shows the ${ }^{1} \mathrm{H}$ NMR spectra corresponding to the low and fast exchange region for the iridium isocyanide complex $\mathbf{5}$. 


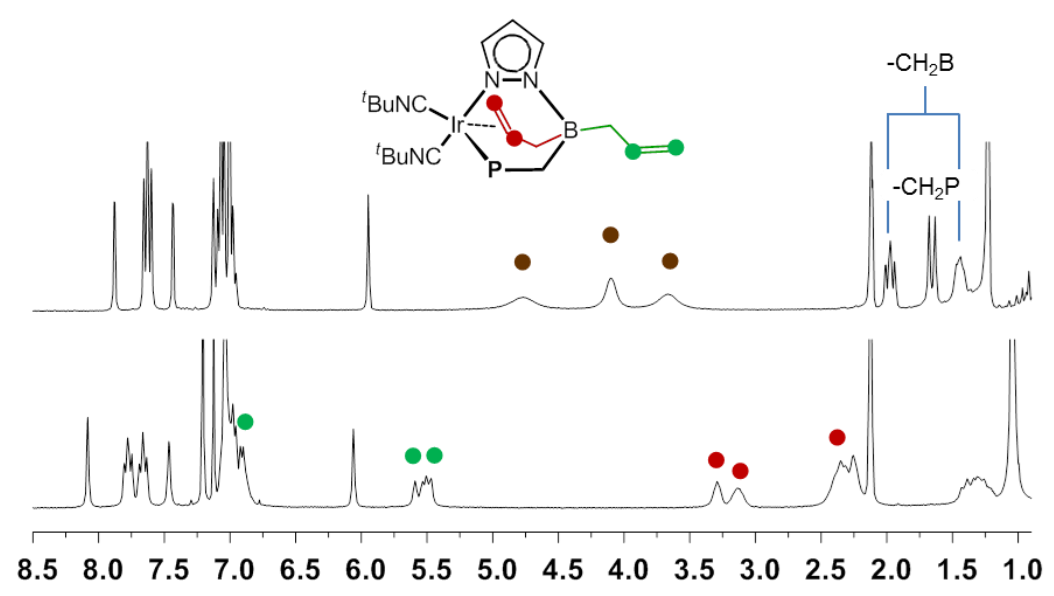

Figure 2. ${ }^{1} \mathrm{H}$ NMR spectra of complex $\left[\operatorname{Ir}\left(\kappa^{3}-\mathrm{A}_{2} \mathrm{BPN}\right)\left(\mathrm{CN}^{t} \mathrm{Bu}\right)_{2}\right](\mathbf{5})$ in $\mathrm{d}_{8}$-toluene, showing the two inequivalent allyl groups at $-50^{\circ} \mathrm{C}$ (bottom) and their fast exchange a r.t. (top).

The electron density at the metal provided by the new $\mathrm{A}_{2} \mathrm{BPN}$ ligand can be deduced from the $v(\mathrm{CO})$ stretchings, which faithfully reflect such event. $S P-4\left[\mathrm{Rh}\left(\kappa^{2}-\mathrm{A}_{2} \mathrm{BPN}\right)(\mathrm{CO})_{2}\right](\mathbf{6})$ shows two intense $v(\mathrm{CO})$ absoptions at 2083 and $2020 \mathrm{~cm}^{-1}$ (cyclohexane), similar to that reported for $\left[\mathrm{Rh}\left(\kappa^{2}-\mathrm{Tp}^{\mathrm{Me} 2}\right)(\mathrm{CO})_{2}\right] \quad\left(2080,2012 \mathrm{~cm}^{-1}\right.$ in pentane $),{ }^{26}$ while that for $T B P Y-5\left[\operatorname{Ir}\left(\kappa^{3}-\right.\right.$ $\left.\left.\mathrm{A}_{2} \mathrm{BPN}\right)(\mathrm{CO})_{2}\right]\left(2053,1982 \mathrm{~cm}^{-1}\right.$, cyclohexane $)$ were found to be closer to that for $\left[\operatorname{Ir}\left(\kappa^{3}-\right.\right.$ $\left.\mathrm{Tp})(\mathrm{CO})_{2}\right]\left(2051,1971 \mathrm{~cm}^{-1}\right.$ in acetonitrile) than for $\left[\operatorname{Ir}\left(\kappa^{3}-\mathrm{Tp}^{\mathrm{Me} 2}\right)(\mathrm{CO})_{2}\right]\left(2035,1954 \mathrm{~cm}^{-1}\right.$ in toluene). ${ }^{27}$ Therefore, the electronic density delivered by $\mathrm{A}_{2} \mathrm{BPN}$ to the metal seems to be similar to that of the $\mathrm{Tp}^{\mathrm{Me} 2}$ ligand in the $\kappa N, \kappa P$ mode, but comparable to $\mathrm{Tp}$ if coordinated in the $\kappa N, \kappa P, \eta^{2}-C=C$ mode.

As indicated above, attempts to isolate $\left[\mathrm{Rh}\left(\kappa^{2}-\mathrm{A}_{2} \mathrm{BPN}\right)(\mathrm{CO})_{2}\right](6)$ led to the loss of one carbonyl ligand with crystallization of the product as the dimer $\left[\left\{\operatorname{Rh}\left(\mathrm{A}_{2} \mathrm{BPN}\right)(\mathrm{CO})\right\}_{2}\right](\mathbf{8})$. Figure 3 shows the molecular structure of $\mathbf{8}$ and selected bond lengths and angles are summarized in Table 2. Complex 8 consists of two mononuclear subunits brought together by two bridging allyl 
groups coordinated in a $\mu-\eta^{2}-\mathrm{C}=\mathrm{C}$ fashion, forming in this way a twelve-membered dimetallacycle. In each metallic subunit, the rhodium atom lies in the center of a slightly distorted square-planar environment with the scorpionate ligand coordinated to the metal through the $\mathrm{N}$ and $\mathrm{P}$ atoms in a chelating fashion. The $\mathrm{CO}$ group is located trans to $\mathrm{N}$ and the fourth coordination site is occupied by the $\mathrm{C}=\mathrm{C}$ double bond of the allyl group from the other metallic subunit. In this geometry, the carbonyl and allyl groups having the greatest trans influence ${ }^{28}$ are mutually cis, while the good $\sigma$-donor pyrazolyl group is opposite the strongest $\pi$ acceptor $(\mathrm{CO}){ }^{29}$

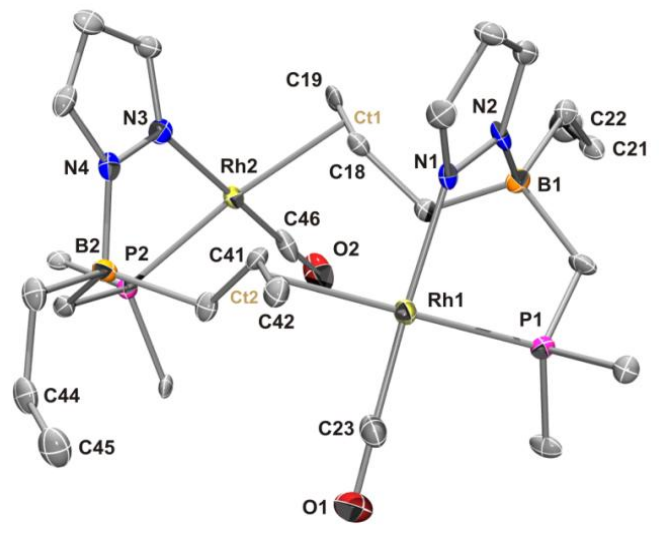

Figure 3. Molecular structure (ORTEP at $50 \%$ level) of complex $\left[\left\{\mathrm{Rh}\left(\mathrm{A}_{2} \mathrm{BPN}\right)(\mathrm{CO})\right\}_{2}\right](8)$. Hydrogen atoms have been removed and only the ipso carbon atoms of the phenyl groups are shown for clarity.

The $\mathrm{Rh}-\mathrm{C}$ (olefin) bond distances (2.305 $\AA$ in average) were found to be considerably longer than those found for some $\mathrm{Rh}(\mathrm{I})$-ethylene complexes. For comparison, average $\mathrm{Rh}-\mathrm{C}$ distances of $2.097,2.125$, and $2.206 \AA$ were observed for square-planar complexes of the type $\left[\mathrm{RhX}(\mathrm{L})_{2}\left(\mathrm{C}_{2} \mathrm{H}_{4}\right)\right],{ }^{30}\left[\mathrm{Rh}\left(\mathrm{L}_{2}\right)\left(\mathrm{C}_{2} \mathrm{H}_{4}\right)_{2}\right],{ }^{31}$ and $\left[\mathrm{Rh}\left(m e r-\mathrm{L}_{3}\right)\left(\mathrm{C}_{2} \mathrm{H}_{4}\right)\right]^{\mathrm{n}+},{ }^{32}$ respectively. Furthermore,

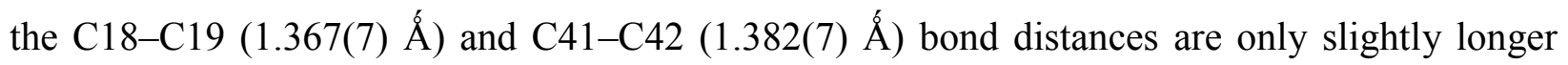


than those observed for the uncoordinated allyl groups (C21-C22, 1.312(7) Á; C44-C45, 1.326(7) $\AA$ ), which indicates it to be a labile ligand with weak $\pi$-back donation from the metal to the olefin. In good agreement, the signals of the coordinated $\mathrm{CH}_{2}=\mathrm{CH}-$ moiety were only slightly shifted upfield (4.91 ppm in average) when compared to the uncoordinated one (5.57 ppm in average) in the ${ }^{1} \mathrm{H}$ NMR spectrum.

Table 2. Selected bond distances $(\AA)$ and angles $\left(^{\circ}\right)$ for complex 8 .

\begin{tabular}{llll}
\hline Rh1-P1 & $2.2864(14)$ & Rh2-P2 & $2.2905(14)$ \\
Rh1-N1 & $2.098(4)$ & Rh2-N3 & $2.108(4)$ \\
Rh1-C41 & $2.291(5)$ & Rh2-C18 & $2.349(4)$ \\
Rh1-C42 & $2.286(5)$ & Rh2-C19 & $2.294(4)$ \\
Rh1-Ct2 & $2.182(5)$ & Rh2-Ct1 & $2.219(4)$ \\
Rh1-C23 & $1.813(6)$ & Rh2-C46 & $1.819(6)$ \\
C18-C19 & $1.367(7)$ & $\mathrm{C} 41-\mathrm{C} 42$ & $1.382(7)$ \\
C21-C22 & $1.312(7)$ & $\mathrm{C} 44-\mathrm{C} 45$ & $1.326(7)$ \\
N1-Rh1-C23 & $176.3(2)$ & $\mathrm{N} 3-\mathrm{Rh} 2-\mathrm{C} 46$ & $175.1(2)$ \\
$\mathrm{P} 1-\mathrm{Rh} 1-\mathrm{Ct} 2$ & $177.6(2)$ & $\mathrm{P} 2-\mathrm{Rh} 2-\mathrm{Ct} 1$ & $171.4(2)$ \\
\hline
\end{tabular}

$\mathrm{Ct} 1$ and $\mathrm{Ct} 2$ represent the middle point of $\mathrm{C} 18$ and $\mathrm{C} 19$, and $\mathrm{C} 41$ and $\mathrm{C} 42$, respectively.

$\mathrm{P}$ - and $\mathrm{N}$-donor ligands cleave the dinuclear unit in $\mathbf{8}$ to generate the square-planar carbonyl complexes $\left[\mathrm{Rh}\left(\kappa^{2}-\mathrm{A}_{2} \mathrm{BPN}\right)(\mathrm{CO}) \mathrm{L}\right]\left(\mathrm{L}=\right.$ pyridine (py), 9; $\left.\mathrm{NH}_{3}, \mathbf{1 0} ; \mathrm{PPh}_{3}, \mathbf{1 1} ; \mathrm{PMe}_{3}, 12\right)$. Complexes 9, 11, and $\mathbf{1 2}$ were isolated as yellow solids in good yields, but the formation of the $\mathrm{NH}_{3}$ compound $\mathbf{1 0}$ was found to be reversible; working-up only led to the recovery of the starting material. It was, however, completely characterized in solution, since its synthesis was 
quantitative (NMR evidence, See Experimental Section). The $\kappa N, \kappa P$-coordination of the ligand to rhodium in these complexes was definitively confirmed from an X-ray study on complex 11, whose molecular structure is shown in Figure 4. Selected bond distances and angles are given in Table 3.

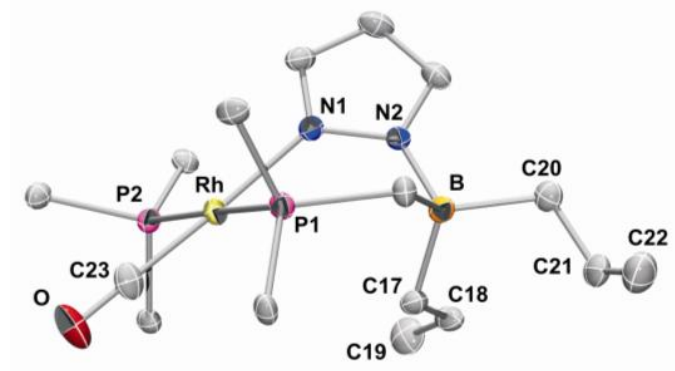

Figure 4. Molecular structure (ORTEP at $50 \%$ level) of complex $\left[\mathrm{Rh}\left(\kappa^{2}-\mathrm{A}_{2} \mathrm{BPN}\right)(\mathrm{CO}) \mathrm{PPh}_{3}\right]$ (11). Hydrogen atoms have been removed and only the ipso carbon atoms of the phenyl groups are shown for clarity.

Table 3. Selected bond distances $(\AA)$ and angles $\left(^{\circ}\right)$ for complex 11.

\begin{tabular}{llll}
\hline Rh-P1 & $2.3042(9)$ & $\mathrm{P} 1-\mathrm{Rh}-\mathrm{P} 2$ & $176.88(3)$ \\
$\mathrm{Rh}-\mathrm{P} 2$ & $2.3313(9)$ & $\mathrm{N} 1-\mathrm{Rh}-\mathrm{C} 23$ & $175.42(12)$ \\
$\mathrm{Rh}-\mathrm{N} 1$ & $2.096(3)$ & $\mathrm{N} 1-\mathrm{Rh}-\mathrm{P} 1$ & $87.20(7)$ \\
$\mathrm{Rh}-\mathrm{C} 23$ & $1.811(3)$ & $\mathrm{P} 2-\mathrm{Rh}-\mathrm{C} 23$ & $87.41(10)$ \\
$\mathrm{C} 18-\mathrm{C} 19$ & $1.313(4)$ & & \\
$\mathrm{C} 21-\mathrm{C} 22$ & $1.322(5)$ & & \\
\hline
\end{tabular}

In the complex, the square-planar rhodium atom is bound to the nitrogen of the pyrazolyl and the phosphorus atoms of the scorpionate ligand, a carbonyl group, and the phosphorus atom from $\mathrm{PPh}_{3}$. Both phosphane donors are placed mutually trans, while the pyrazolyl group remains trans 
to the strongest $\pi$ acceptor $(\mathrm{CO})$ as observed for 8. The six-membered metallacycle ( Rh-N-N-B-C-P ) shows the expected puckered conformation, which minimizes the steric repulsion between the $\mathrm{H}^{3}$ proton from the pyrazolyl and the phenyl groups of $\mathrm{PPh}_{3}$. The terminal CO ligands in 9-12 were located cis to the phosphane arm of the ligand $\left(J_{\mathrm{C}, \mathrm{P}}=12-17 \mathrm{~Hz}\right)$, while both allyl groups were found to be non-coordinated to rhodium $\left({ }^{1} \mathrm{H}\right.$ NMR evidence), information that confirms that they are square-planar complexes with the ligand in the bidentate $\kappa N, \kappa P$ coordination mode (Chart 1). Moreover, as found for $\mathbf{1 1}$ in the solid state, both phosphane groups in 11 and 12 showed a mutual trans disposition as deduced from the large $J_{\mathrm{P}^{\mathrm{A}},{ }^{\mathrm{B}}}$ values of 297 and $309 \mathrm{~Hz}$, respectively. Furthermore, the $v(\mathrm{CO})$ stretching (toluene/ $\mathrm{C}_{6} \mathrm{D}_{6}$ ) of complexes 9-12 (1977, 1972, 1981, and $1977 \mathrm{~cm}^{-1}$, respectively) reflects a weak influence of the basicity of the ligands (pyridine, $\mathrm{NH}_{3}, \mathrm{PMe}_{3}$, and $\mathrm{PPh}_{3}$, respectively) on the electronic density of the metal.

Chart 1. Stereochemistry of complexes 9-14.

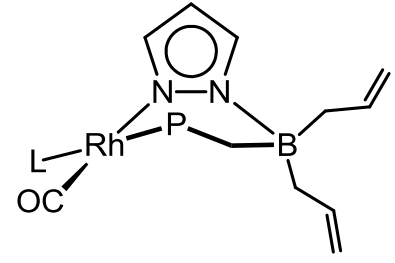

$L=P y(9), \mathrm{NH}_{3}(10)$

$\mathrm{PPh}_{3}$ (11), $\mathrm{PMe}_{3}(12)$

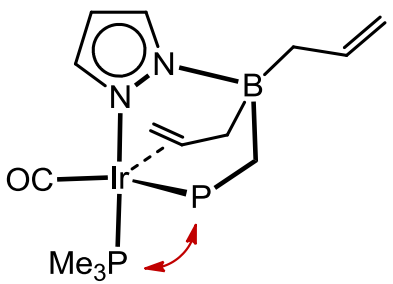

14 (TBPY-5-31_CO $\left.O_{\text {eq }}\right)$

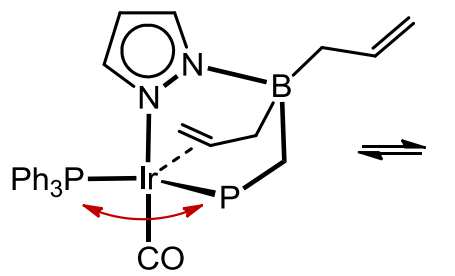

13a (TBPY-5-34_CO $\left.{ }_{\mathrm{ax}}\right)$

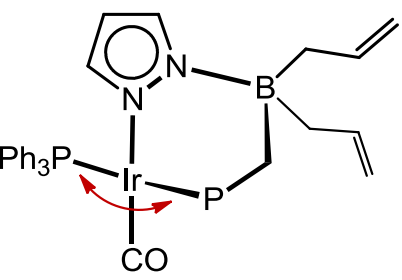

$13 b(S P-4)$

The iridium counterparts $\left[\operatorname{Ir}\left(\kappa^{3}-\mathrm{A}_{2} \mathrm{BPN}\right)(\mathrm{CO}) \mathrm{PR}_{3}\right](\mathrm{R}=\mathrm{Ph}, \mathbf{1 3} ; \mathrm{Me}, 14)$ were isolated as white solids in good yields by treating the bis-carbonyl complex 7 with the corresponding phosphanes. Both complexes displayed the typical features for pentacoordinated species (with an allyl bonded to iridium) in their ${ }^{1} \mathrm{H}$ and ${ }^{13} \mathrm{C}\left\{{ }^{1} \mathrm{H}\right\}$ NMR spectra at low temperature, while they showed a single 
$v(\mathrm{CO})$ band in their solid state IR spectra. However, it was very surprising the divergence in values of this stretching, $2008 \mathrm{~cm}^{-1}$ for the $\mathrm{PPh}_{3}$ complex 13 and $1920 \mathrm{~cm}^{-1}$ for the $\mathrm{PMe}_{3}$ analogue 14, a difference too large $\left(88 \mathrm{~cm}^{-1}\right)$ to be explained by considering only the basicity of the phosphane ligands. Moreover, the $J_{\mathrm{P}^{\mathrm{A}}}, \mathrm{P}^{\mathrm{B}}$ coupling constants in the ${ }^{31} \mathrm{P}\left\{{ }^{1} \mathrm{H}\right\}$ NMR spectra at low temperature ( $45 \mathrm{~Hz}$ for $\mathbf{1 3}$ and $12 \mathrm{~Hz}$ for 14) suggest a coupling of the type ${ }^{2} J_{\text {Peq,Peq }}$ for the former while ${ }^{2} J_{\text {Peq,Pax }}$ for the later. ${ }^{33,}{ }^{34}$ Consequently, complexes $\mathbf{1 3}$ and $\mathbf{1 4}$ differ in their stereochemistry. Thus, the axial location of the CO ligand in $\mathbf{1 3}$ accounts for the high $v(\mathrm{CO})$ stretching, while the low frequency for $\mathbf{1 4}$ is consistent with the binding of this ligand in an equatorial position. In fact, theoretical studies on pentacoordinated $\mathrm{d}^{8}$-complexes ${ }^{35}$ predict a strong metal-ligand $\pi$-interaction in the equatorial position, so that lower $\mathrm{v}(\mathrm{CO})$ frequencies can be expected for $\mathrm{CO}(\mathrm{eq})$ when compared to those for $\mathrm{CO}(\mathrm{ax})$ in similar complexes. Moreover, a survey of the reported $\mathrm{v}(\mathrm{CO})$ frequencies in $T B P Y-5$ iridium complexes of general formula $\left[\operatorname{IrR}(\mathrm{CO})(\text { olefin }) \mathrm{P}_{2}\right]^{36}$ and related ones containing $f a c$-tripodal ligands of the type $\left[\operatorname{Ir}\left(\kappa^{3}-\right.\right.$ $\left.\mathrm{L}_{3}\right)(\mathrm{CO})(\text { olefin) }]^{37}$ agree with this consideration. Hence, we propose a TBPY-5-34_CO $\mathrm{Cx}_{\mathrm{ax}}$ configuration for $\mathbf{1 3}$ and TBPY-5-31_CO $\mathrm{CO}_{\mathrm{eq}}$ for $\mathbf{1 4}$ (Chart 1) to account for the spectroscopic data.

Further support from this proposal comes from DFT studies carried out on the two possible $T B P Y-5$ isomers of $\mathbf{1 3}$ and 14. The $T B P Y-5-34{ }_{-} \mathrm{CO}_{\mathrm{ax}}$ configuration for $\left[\operatorname{Ir}\left(\mathrm{\kappa}^{3}-\mathrm{A}_{2} \mathrm{BPN}\right)(\mathrm{CO}) \mathrm{PPh}_{3}\right]$ (13) was found to be $4.8 \mathrm{kcal} \mathrm{mol}^{-1}$ more stable $(\Delta G)$ than the $T B P Y-5-31{ }_{-} \mathrm{CO}_{\mathrm{eq}}$, which was found to be samewhat distorted due to the steric hindrance of the close phosphane groups (Figure 5). On the contrary, the configuration with the $\mathrm{CO}$ ligand in the equatorial plane was found to be $2.5 \mathrm{kcal} \mathrm{mol}^{-1}$ more stable than that with an axial carbonyl in $\left[\operatorname{Ir}\left(\kappa^{3}-\mathrm{A}_{2} \mathrm{BPN}\right)(\mathrm{CO}) \mathrm{PMe}_{3}\right](\mathbf{1 4})$. Moreover, the observed $v(\mathrm{CO})$ stretching frequencies fit nicely with the DFT calculated ones for the proposed structures (Table 4). 

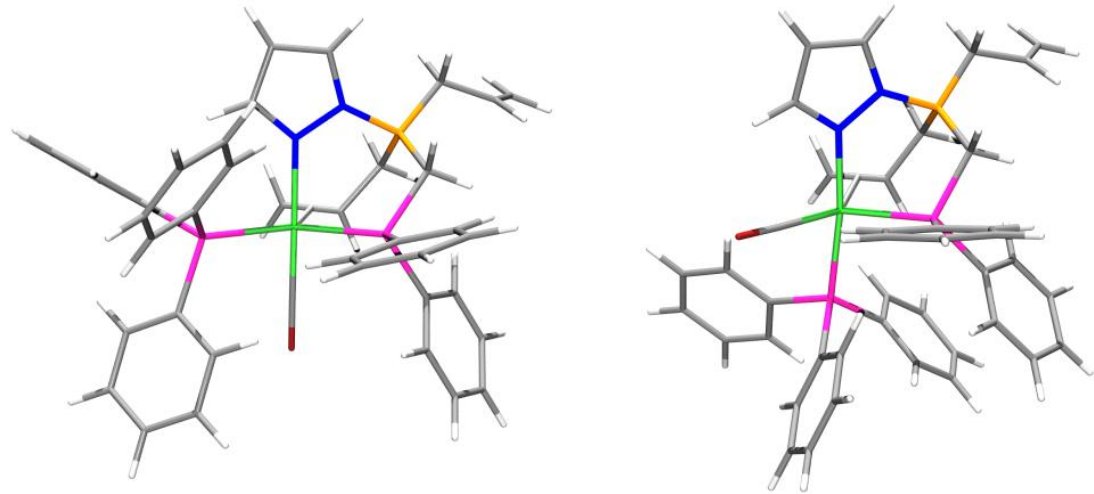

Figure 5. DFT optimized (b3-lyp, TZVP) geometries of $\left[\operatorname{Ir}\left(\kappa^{3}-\mathrm{A}_{2} \mathrm{BPN}\right)(\mathrm{CO}) \mathrm{PPh}_{3}\right](\mathbf{1 3})$ in different configurations: TBPY-5-34_CO $\mathrm{CO}_{\mathrm{ax}}$ isomer (left) and TBPY-5-31_CO eq (right). Code color: Ir (green), N (blue), P (pink), B (orange) and O (red). P-Ir-P angles $\left(^{\circ}\right)$ : 115.7 and 101.6 for $T B P Y-5-34 \mathrm{CO}_{\mathrm{ax}}$ and $T B P Y-5-31 \mathrm{CO}_{\mathrm{eq}}$, respectively.

Table 4. Experimental and DFT calculated $v(\mathrm{CO})$ stretching frequencies for $\mathbf{1 3}$ and $\mathbf{1 4 .}$

\begin{tabular}{ccccc|cccc}
\hline \multicolumn{4}{c|}{$\left[\operatorname{Ir}\left(\mathrm{A}_{2} \mathrm{BPN}\right)(\mathrm{CO}) \mathrm{PPh}_{3}\right](\mathbf{1 3})$} & \multicolumn{4}{c}{$\left[\operatorname{Ir}\left(\kappa^{3}-\mathrm{A}_{2} \mathrm{BPN}\right)(\mathrm{CO}) \mathrm{PMe}_{3}\right](\mathbf{1 4})$} \\
\hline \multirow{2}{*}{ solid } & toluene & $T B P Y-5-34$ & $S P-4$ & $T B P Y-5-31$ & solid & toluene & $T B P Y-5-34$ & $T B P Y-5-31$ \\
\hline 2008 & $\begin{array}{l}2000, \\
1978\end{array}$ & 2004 & 1971 & 1938 & 1920 & 1928 & 1992 & 1935 \\
& & & & & & & \\
\hline
\end{tabular}

Calculated DFT-frequencies have been corrected by a factor of 0.996 .

For the TBPY-5 configurations, the better $\pi$-acceptor ligands are expected to be found at the equatorial positions. Complex $\left[\operatorname{Ir}\left(\kappa^{3}-\mathrm{A}_{2} \mathrm{BPN}\right)(\mathrm{CO}) \mathrm{PMe}_{3}\right](\mathbf{1 4})$ follows this general trend, since the $\mathrm{CO}$ and $\mathrm{C}=\mathrm{C}$ groups lie at equatorial sites. However, steric effects can reverse this trend, as shown for $\left[\operatorname{Ir}\left(\kappa^{3}-\mathrm{A}_{2} \mathrm{BPN}\right)(\mathrm{CO}) \mathrm{PPh}_{3}\right](\mathbf{1 3})$, in which the $\mathrm{CO}$ ligand is located at the axial site to minimize the steric hindrance provided by the bulky phenyl groups. This effect is expected to 
reach a maximum in a square-planar configuration (Chart 1), since both P-ligands separate from 120 to $180^{\circ}$. The NMR spectra at room temperature of $\mathbf{1 3}$ features equivalent free allyl groups and a coupling constant $J_{\mathrm{P}^{\mathrm{A}}, \mathrm{P}^{\mathrm{B}}}=194 \mathrm{~Hz}$, close to the expected value for a square-planar trans stereochemistry (ca. $300 \mathrm{~Hz}$ ). Therefore, a fast equilibrium between pentacoordinated (13a) and square-planar (13b) geometries (Chart 1) accounts for the NMR data at room temperature. Such equilibrium can be ascribed to the steric pressure exerted by the bulky $\mathrm{PPh}_{3}$ ligand, which would facilitate the dissociation of the allyl arm. The VT-NMR spectroscopic data were analyzed with a Van 't Hoff plot, which provided the following thermodynamic parameters associated with the equilibrium 13a $\rightleftharpoons$ 13b: $\Delta H^{\circ}=+2.7 \pm 0.1 \mathrm{kcal} \mathrm{mol}^{-1}$ and $\Delta S^{\circ}=+9.3 \pm 0.5 \mathrm{cal} \mathrm{mol}^{-1} \mathrm{~K}^{-1}$, which results in $\Delta G^{\circ}{ }_{293.15}=-0.045 \mathrm{kcal} \mathrm{mol}^{-1}$. In good agreement, values of $+3.28 \mathrm{kcal} \mathrm{mol}^{-1}\left(\Delta H^{\circ}\right)$ and $-0.20 \mathrm{kcal} \mathrm{mol}^{-1}\left(\Delta G^{\circ}{ }_{293.15}\right)$ were obtained from DFT calculations (see supporting information).

Moreover, both isomers were detected by IR spectroscopy in solution by two broad $v(\mathrm{CO})$ bands at $2000(\mathrm{~m})$ and $1978(\mathrm{~s}) \mathrm{cm}^{-1}$, corresponding to the minor TBPY-5-34_CO $\mathrm{ax}_{\mathrm{ax}}$ and the major square-planar isomers, respectively. Again, the frequency of the $v(\mathrm{CO})$ band for the trans square-planar isomer (SP-4) matchs satisfactorily with that found by DFT-calculations (Table 4).

On the other hand, complex $\left[\operatorname{Ir}\left(\kappa^{3}-\mathrm{A}_{2} \mathrm{BPN}\right)(\mathrm{CO}) \mathrm{PMe}_{3}\right](\mathbf{1 4})$ was found to be the sole isomer with a TBPY-5-31_CO $\mathrm{CO}_{\text {eq }}$ configuration at room temperature, according to the NMR and IR spectra (see Experimental Section), and hence electronic issues dominates the stereochemistry in this case.

The different structure of the main isomers of $\mathbf{1 3}$ and $\mathbf{1 4}$ is largely responsible for the reactivity pattern observed in their reactions of protonation. Both complexes reacted readily with dry $\mathrm{HCl}$ in a 1:1 molar ratio affording the $\operatorname{Ir}(\mathrm{III})$ complexes $\left[\operatorname{Ir}\left(\kappa^{2}-\mathrm{A}_{2} \mathrm{BPN}\right)(\mathrm{CO})(\mathrm{Cl})(\mathrm{H}) \mathrm{PPh}_{3}\right](\mathbf{1 5})$ and 
isolated as white solids in good yields (Scheme 5).

Scheme 5. Protonation reactions of $\mathbf{1 3}$ and $\mathbf{1 4}$ leading to complexes 15 and $\mathbf{1 6 .}$
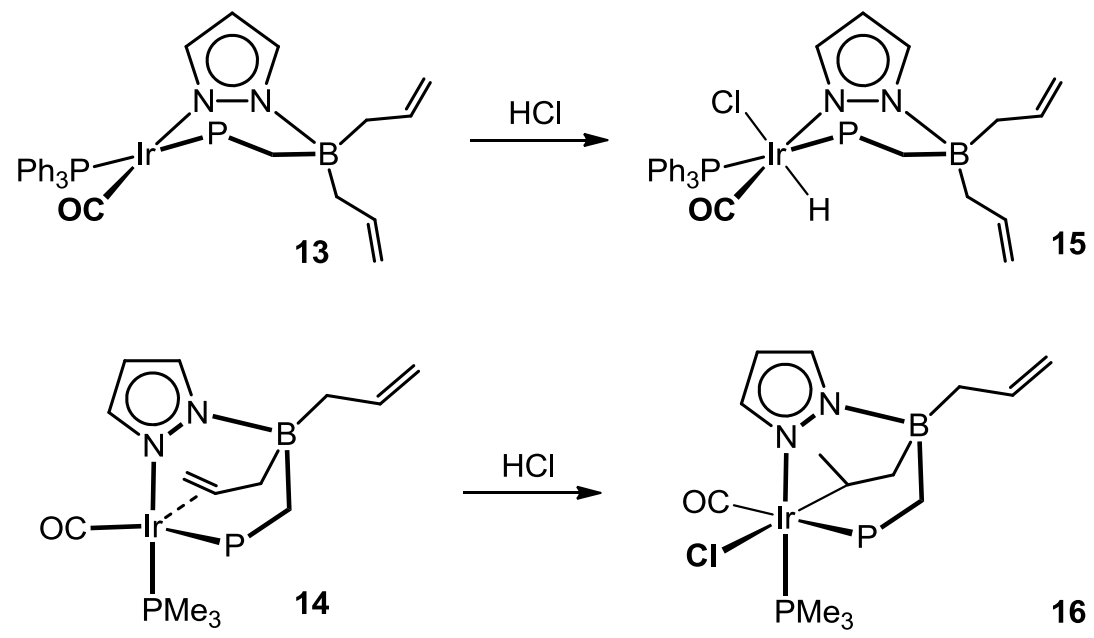

Characterization of complex $\mathbf{1 5}$ was achieved by a combination of the usual spectroscopic and analytical methods, which allowed to detect the phosphane groups mutually trans, and the hydrido (at $\delta=-14.47$ ) and CO ligands cis to both $\mathrm{P}$ atoms and mutually cis to each other (See Experimental Section). These data indicated that complex $\mathbf{1 5}$ is octahedral with the scorpionate ligand adopting a $\kappa P, \kappa N$ coordination mode and the other four sites occupied by $\mathrm{PPh}_{3}, \mathrm{CO}$, the hydride and a chloride ligand, a chemical composition confirmed by MALDI spectrometry. Moreover, the shift to higher frequency of the $v(\mathrm{CO})$ band, at $2058 \mathrm{~cm}^{-1}$, is in accordance with a decrease of the electron density on the metal or an $\operatorname{Ir}(\mathrm{III})$ oxidation state in $\mathbf{1 5 .}$

Protonation of $\mathrm{PMe}_{3}$ complex 14 with hydrogen chloride followed a different profile and afforded the neutral complex 16, which did not show hydrido signals in the ${ }^{1} \mathrm{H}$ NMR spectrum. Instead, there was a new set of resonances that corresponded to a $\sigma$-bonded ' $-\mathrm{CH}(\mathrm{Me}) \mathrm{CH}_{2} \mathrm{~B}$ ' moiety. The spectroscopic data collected for $\mathbf{1 6}$ unambiguously pointed out to the octahedral 
structure shown in Scheme 5, which features a new hydrocarbyl arm $\sigma$-bonded to iridium (see Experimental Section for details). The $v(\mathrm{CO})$ band observed at $2061 \mathrm{~cm}^{-1}$ confirmed the oxidation of the metal to Ir(III) in the reaction. Complex 16 showed a static ${ }^{1} \mathrm{H}$ NMR spectrum with several features to be noticed. One of the allyl arms is uncoordinated, while a different set of resonances were deduced to correspond to the new hydrocarbyl fragment arising formally from a Markovnikov addition of the proton to the $\mathrm{C}=\mathrm{C}$ bond of the other allyl fragment. The low coupling constant $J_{\mathrm{P}^{\mathrm{A}}, \mathrm{P}^{\mathrm{B}}}=22 \mathrm{~Hz}$ indicated a mutual cis disposition of both phosphanes. In addition, two well differentiated coupling constants were observed for the terminal $\mathrm{CO}\left(J_{\mathrm{C}, \mathrm{P}}=\right.$ 132 and $9 \mathrm{~Hz}$ ) in the ${ }^{13} \mathrm{C}\left\{{ }^{1} \mathrm{H}\right\}$ NMR spectrum, which located $\mathrm{CO}$ cis to $\mathrm{PMe}_{3}$ and trans to the phosphane arm due to the $f a c$ imposed coordination of the scorpionate ligand. In this way, NMR data of complex $\mathbf{1 6}$ reflect accurately the structure and stereochemistry also found for the closely related compound $\left[\operatorname{Ir}\left\{(\mathrm{Hpz}) \mathrm{B}\left(\mathrm{CH}_{2} \mathrm{CHCH}_{3}\right)\left(\mathrm{CH}_{2} \mathrm{PPh}_{2}\right)(\mathrm{Pz})\right\}(\mathrm{Cl})(\mathrm{CO}) \mathrm{PMe}_{3}\right] \mathrm{Cl}^{18}$

Structural comparison between the $\operatorname{Ir}(\mathrm{III})$ complexes $\mathbf{1 5}$ and $\mathbf{1 6}$ reveals information about the mechanisms following protonation of $\mathbf{1 3}$ and $\mathbf{1 4}$ with $\mathrm{HCl}$. The square-planar isomer of $\mathbf{1 3}$ is favored for a direct protonation at the iridium centre (Figure 6, left) from the external face to give the square pyramidal intermediate with the coordination vacancy trans to the hydride ligand. Then, a fast inversion of the metallacycle places the hydride ligand inside the pocket of the complex allowing the coordination of the chloride again at the less hindered external face to give the product from a trans oxidative-addition of $\mathrm{HCl}$ (Scheme 6). ${ }^{38}$

Scheme 6. Proposed mechanism for the protonation of complex 13.

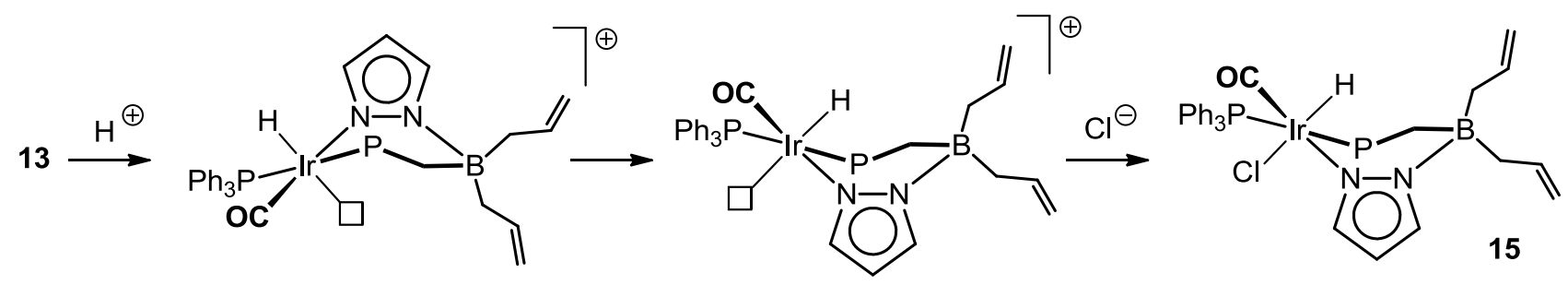


Regarding the protonation of the $\mathrm{PMe}_{3}$ compound 14, a similar path would require the previous decoordination of the allyl arm, a dynamic process that was not observed by NMR. Nonetheless, complex 14 shows a HOMO mainly formed by the $\mathrm{d}_{\mathrm{x}-\mathrm{y}}^{2}{ }^{2}$ orbital of the iridium atom backdonating to both, the $\pi^{*}$ orbital of rhe $\mathrm{C}=\mathrm{C}$ group and the $\pi^{*}$ orbital of the $\mathrm{C}=\mathrm{O}$ ligand (Figure 6).
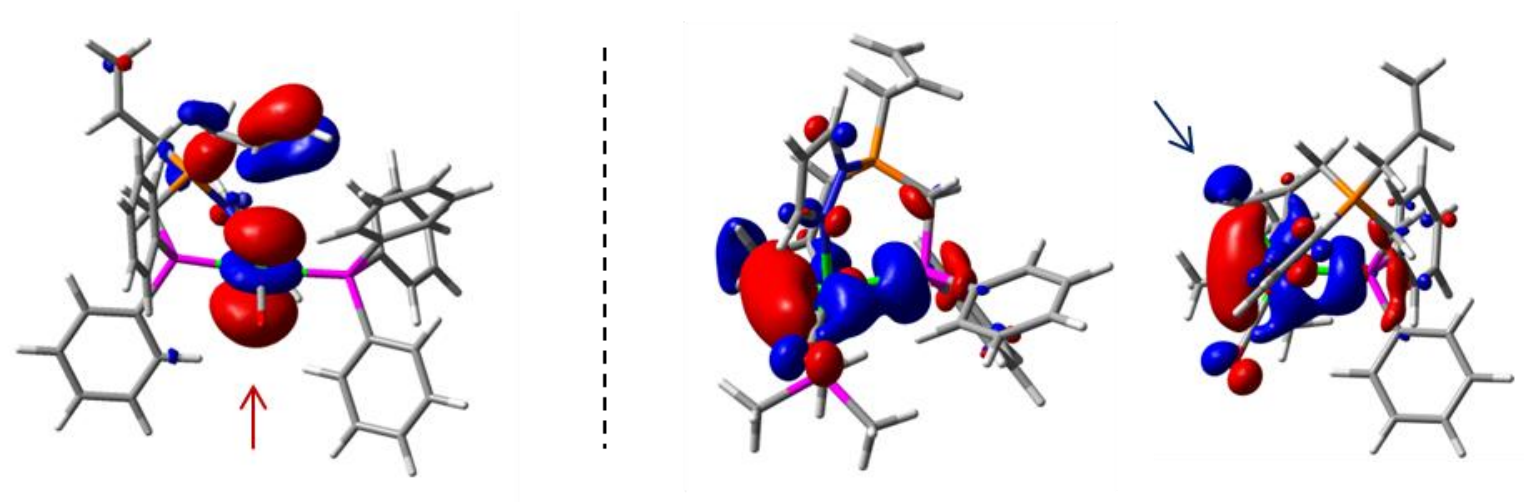

Figure 6. HOMO of $S Q-4-\left[\operatorname{Ir}\left(\kappa^{2}-\mathrm{A}_{2} \mathrm{BPN}\right)(\mathrm{CO}) \mathrm{PPh}_{3}\right](13$, left $)$ and two views of the HOMO of TBPY-5-31_CO $\mathrm{CO}_{\text {eq }}-\left[\operatorname{Ir}\left(\kappa^{3}-\mathrm{A}_{2} \mathrm{BPN}\right)(\mathrm{CO}) \mathrm{PMe}_{3}\right](\mathbf{1 4})$. The red arrow indicates the external face of the complex while that in blue indicates the $\mathrm{H}_{2} \mathrm{C}=$ carbon from the coordinated allyl arm.

Consequently, a direct Markovnikov addition of the proton to the $\mathrm{H}_{2} \mathrm{C}=$ carbon (marked with the blue arrow in Figure 6) seems to be the most probable initial step, although the protonation of the metal followed by insertion of the coplanar olefin into the $\mathrm{Ir}-\mathrm{H}$ bond cannot be fully excluded. A further binding of the chloride at the coordination vacancy (trans to the alkyl group) would give the protonation product 16 (Scheme 7).

Scheme 7. Proposed mechanism for the protonation of complex 14.

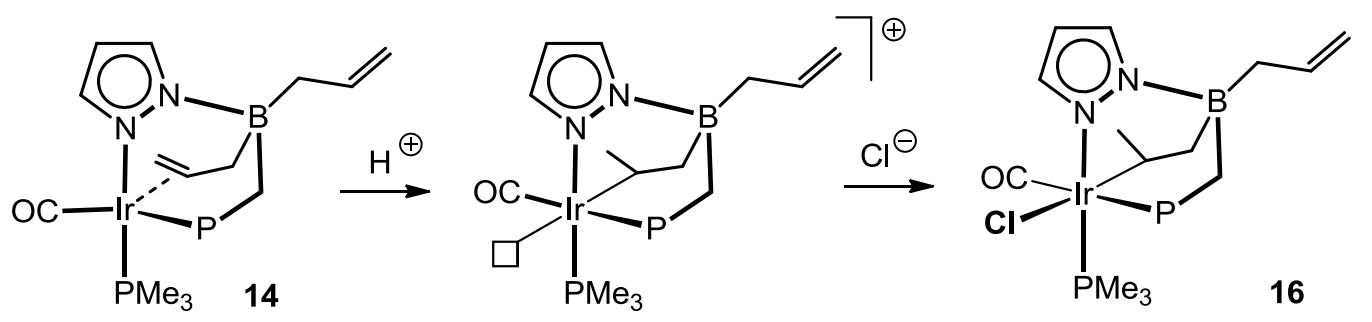


Related complexes of formula $\left[\operatorname{Ir}\left(\kappa^{3}-\mathrm{A}_{2} \mathrm{BPN}\right)(\mathrm{CO}) \mathrm{L}\right]\left(\mathrm{L}=\mathrm{H}_{2} \mathrm{C}=\mathrm{CH}_{2}, 17 ; \mathrm{MeO}_{2} \mathrm{CC} \equiv \mathrm{CCO}_{2} \mathrm{Me}\right.$, 18) were prepared by reacting the bis(carbonyl) compound 7 with ethylene or $\mathrm{MeO}_{2} \mathrm{CC} \equiv \mathrm{CCO}_{2} \mathrm{Me}$ (dmad), respectively (Chart 2). The ethylene complex 17 was found to be static at room temperature (i.e. no ethylene rotation around the $\operatorname{Ir}-\mathrm{C}_{2} \mathrm{H}_{4}$ axis takes place on the NMR time scale), which agrees with a $\eta^{2}-(C=C)$ coordination coplanar with the equatorial plane of a trigonal bipyramidal arrangement. As a matter of fact, ${ }^{1} \mathrm{H}-{ }^{1} \mathrm{H}$ NOESY experiments corroborated the ethylene ligand to be in the equatorial site of the TBPY-5 geometry, since the olefinic protons located upwards the equatorial plane (marked with red circles) gave a strong NOE effect with the $\mathrm{H}^{3}$ proton of the pyrazolyl arm (Chart 2). Accordingly, the $v(\mathrm{CO})$ stretching $\left(\mathrm{C}_{6} \mathrm{D}_{6}\right)$ at $2013 \mathrm{~cm}^{-1}$ fits quite well to that expected for a carbonyl ligand at the axial site, as observed for complex $13 .{ }^{39}$ Since steric arguments can be ruled out because of the small size of the ethylene ligand, we can conclude that the TBPY-5-23_ $\mathrm{CO}_{\mathrm{ax}}$ configuration represents the most stable isomer on the basis of electronic issues as observed for related complexes. ${ }^{39}$

Chart 2. Stereochemistry of complexes 17-18.

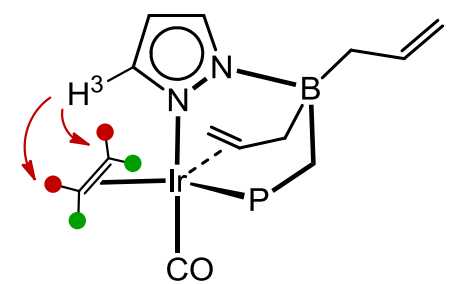

17 (TBPY-5-23_COax)

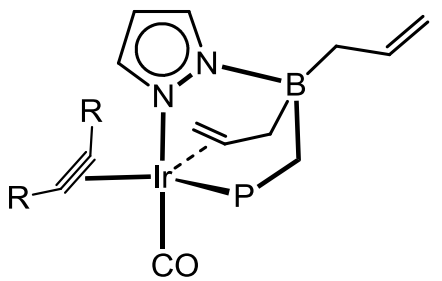

18 (TBPY-5-23_COax, $\left.\mathrm{R}=\mathrm{CO}_{2} \mathrm{Me}\right)$

Concerning the complex $\left[\operatorname{Ir}\left(\kappa^{3}-\mathrm{A}_{2} \mathrm{BPN}\right)(\mathrm{CO})(\mathrm{dmad})\right](\mathbf{1 8})$, in which ethylene is formally replaced by a dimethyl acetylenedicarboxylate ligand in $\mathbf{1 7}$, spectroscopic data indicated both to be similar, as confirmed by a X-ray difraction study for $\mathbf{1 8}$. Figure 7 shows the ORTEP representation of the molecule and Table 5 collects selected bond lengths and angles. The iridium center in $\mathbf{1 8}$ has a distorted trigonal bipyramidal environment with the pyrazolyl and the 
CO ligands occupying the axial sites, while the equatorial plane is defined by the phosphane arm, the $\eta^{2}$-bonded allyl fragment and the $\pi$-bonded acetylene with its initial triple bond asymmetrically bound and lying in the equatorial plane.

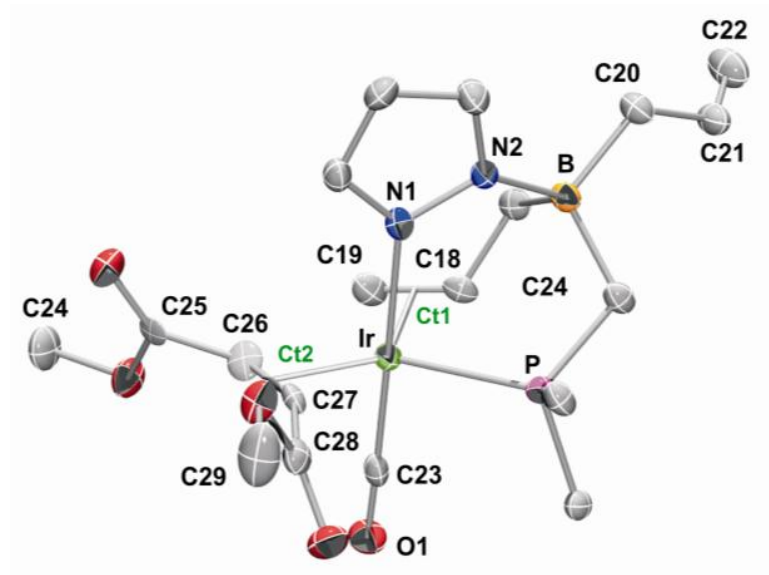

Figure 7. Molecular structure (ORTEP at $50 \%$ level) of complex $\left[\operatorname{Ir}\left(\kappa^{3}-\mathrm{A}_{2} \mathrm{BPN}\right)(\mathrm{CO})(\mathrm{dmad})\right]$ (18). Hydrogen atoms and solvent of crystallization have been removed and only the ipso carbon atoms of the phenyl groups are shown for clarity.

The length of the acetylenic $\mathrm{C} 26^{-} \mathrm{C} 27$ linkage expands from ca. 1.20 to $1.246(9) \AA$ upon coordination, and possesses a cis-bent configuration associated with angles at the acetylenic carbons of $\mathrm{C} 25^{-} \mathrm{C} 26^{-} \mathrm{C} 27=147.3(7)^{\circ}$ and $\mathrm{C} 26^{-} \mathrm{C} 27^{-} \mathrm{C} 28=147.7(7)^{\circ}$, comparable to those found in other dmad iridium complexes such as $\left[\operatorname{Ir}\left(\mathrm{COCH}_{2} \mathrm{CMe}_{3}\right)\left(\mathrm{P}(p \text {-tolyl })_{3}\right)(\mathrm{dmad})\right]^{39}$ and $\left[\mathrm{IrMe}(\mathrm{CO})\left(\mathrm{PPh}_{3}\right)_{2}(\mathrm{dmad})\right]^{40}$

Table 5. Selected bond distances $(\AA)$ and angles $\left({ }^{\circ}\right)$ for complex 18.

\begin{tabular}{llll}
\hline $\mathrm{Ir}-\mathrm{P}$ & $2.3543(19)$ & $\mathrm{N} 1-\mathrm{Ir}-\mathrm{C} 23$ & $179.2(3)$ \\
$\mathrm{Ir}-\mathrm{N} 1$ & $2.097(6)$ & $\mathrm{Ct} 1-\mathrm{Ir}-\mathrm{Ct} 2$ & $133.7(3)$ \\
$\mathrm{Ir}-\mathrm{Ct} 1$ & $2.164(7)$ & $\mathrm{P}-\mathrm{Ir}-\mathrm{Ct} 1$ & $102.2(2)$
\end{tabular}




$\begin{array}{llll}\mathrm{Ir}-\mathrm{Ct} 2 & 2.019(7) & \mathrm{P}-\mathrm{Ir}-\mathrm{Ct} 2 & 123.5(2) \\ \mathrm{Ir}-\mathrm{C} 23 & 1.856(7) & \mathrm{N} 1-\mathrm{Ir}-\mathrm{Ct} 1 & 88.6(2) \\ \mathrm{C} 18-\mathrm{C} 19 & 1.383(9) & \mathrm{N} 1-\mathrm{Ir}-\mathrm{Ct} 2 & 87.5(2) \\ \mathrm{C} 21-\mathrm{C} 22 & 1.326(10) & \mathrm{N} 1-\mathrm{Ir}-\mathrm{P} & 86.9(2) \\ \mathrm{C} 26-\mathrm{C} 27 & 1.246(9) & & \end{array}$

$\mathrm{Ct} 1$, and $\mathrm{Ct} 2$ represent the middle point of $\mathrm{C} 18$ and $\mathrm{C} 19$, and $\mathrm{C} 27$ and $\mathrm{C} 28$, respectively.

Spectroscopic data in solution for complex $18\left({ }^{1} \mathrm{H},{ }^{31} \mathrm{P}\left\{{ }^{1} \mathrm{H}\right\},{ }^{13} \mathrm{C}\left\{{ }^{1} \mathrm{H}\right\}\right.$ NMR and IR spectra) are consistent with the pentacoordinated structure found in the solid state. In particular, the chemical shifts for the $\mathrm{C}_{s p}$ atoms of the coordinated alkyne ( $\delta 91.5$ and $\left.86.9 \mathrm{ppm}\right)$ compare well with those found in the structurally related complex $\left[\operatorname{Ir}\left(\mathrm{Tp}^{\mathrm{Me}}\right)(\mathrm{CO})(\mathrm{dmad})\right](86.2 \mathrm{ppm}),{ }^{41}$ while the quite different coupling constants $J_{\mathrm{C}, \mathrm{P}}$ of 7 and $40 \mathrm{~Hz}$, respectively, reflect a $\mathrm{C} 27-\mathrm{Ir}-\mathrm{P}$ angle $\left(106.3(2)^{\circ}\right)$ more closed than the related C26-Ir-P angle $\left(140.4(2)^{\circ}\right)$. The distinct coupling constants also confirm the lack of rotation of the acetylene around the $\operatorname{Ir}-\mathrm{C} \equiv \mathrm{C}$ axis, since otherwise similar averaged coupling constants would be observed. The better $\pi$-aceptor character of dmad respect to ethylene is clearly observable from blue-shift of the $v(\mathrm{CO})$ stretching in the IR spectra from 2013 (17) to $2040 \mathrm{~cm}^{-1}$ (18).

The isoelectronic isocyanide compound $\left[\operatorname{Ir}\left(\kappa^{3}-\mathrm{A}_{2} \mathrm{BPN}\right)\left(\mathrm{CN}^{t} \mathrm{Bu}\right)_{2}\right](\mathbf{5})$ reacted with dmad in a different way keeping the isocyanide ligands to afford the complex $\left[\operatorname{Ir}\left(\kappa^{2}-\right.\right.$ $\left.\left.\mathrm{A}_{2} \mathrm{BPN}\right)\left(\mathrm{CN}^{t} \mathrm{Bu}\right)_{2}(\mathrm{dmad})\right]$ (19) in good yields. Moreover, two inequivalent non-coordinated allylic arms were clearly observable in the ${ }^{1} \mathrm{H}$ and ${ }^{13} \mathrm{C}\left\{{ }^{1} \mathrm{H}\right\}$ NMR spectra of 19. In addition, the coordinated dmad showed coupling constants $J_{\mathrm{C}, \mathrm{P}}$ of 6 and $66 \mathrm{~Hz}$, the later suggesting an angle C-Ir-P bigger than $140^{\circ}$, which is intermediate between octahedral (OC-6) and TBPY-5 
geometries around iridium. Furthermore, the IR stretching frequencies of the isocyanide ligands in complex 19 are shifted ca. $116 \mathrm{~cm}^{-1}$ to higher frequencies relative to $\mathbf{5}$.

Most probably, the different reactivity involving the addition of dmad to complexes $\left[\operatorname{Ir}\left(\kappa^{3}-\right.\right.$ $\left.\left.\mathrm{A}_{2} \mathrm{BPN}\right)(\mathrm{L})_{2}\right]\left(\mathrm{L}=\mathrm{CN}^{t} \mathrm{Bu}, 5 ; \mathrm{CO}, 7\right)$ could be ascribed to the stronger bonding of the isocyanide to iridium. In fact, complex $\left[\operatorname{Ir}\left(\kappa^{3}-\mathrm{A}_{2} \mathrm{BPN}\right)(\mathrm{CO})(\mathrm{dmad})\right](\mathbf{1 8})$ is even formed in the presence of a carbon monoxide atmosphere.

\section{Conclusion}

Summarizing, we report the straightforward synthesis of a novel hybrid scorpionate ligand $\left[(\text { allyl })_{2} \mathrm{~B}\left(\mathrm{CH}_{2} \mathrm{PPh}_{2}\right)(\mathrm{Pz})\right]^{-}$, which is equipped with different donors, including hard $\mathrm{N}$ and soft $\mathrm{P}$ and $\mathrm{C}$ atoms. We have disclosed the coordination behaviour of this ligand system, which has proven to be highly versatile in stabilizing rhodium and iridium metallic complexes in a number of different coordination modes. The Rh(I) complexes are square-planar, with the ligand coordinated in a bidentate $\kappa N, \kappa P$ fashion, although in a specific example (i.e the dinuclear carbonyl complex $\left.\left[\left\{\operatorname{Rh}\left(\mathrm{A}_{2} \mathrm{BPN}\right)(\mathrm{CO})\right\}_{2}\right]\right)$ the ligand adopts the unexpected $\kappa N, \kappa P, \mu-\eta^{2}-(C=C)$ coordination mode. A general behaviour observed for these rhodium complexes is the dynamic fast inversion of the six-membered metallacycle $(\stackrel{\mathrm{Rh}-\mathrm{N}-\mathrm{N}-\mathrm{B}-\mathrm{C}-\mathrm{P}}{)}$.

The Ir(I) complexes described herein tend to adopt pentacoordinated $T B P Y-5$ geometries with one allyl arm coordinated, i.e. the ligand adopts a $\kappa N, \kappa P, \eta^{2}-(C=C)$ coordination mode. The lability of the Ir-allyl interaction and the flexibility of the ligand architecture lead to distinct behavior in solution. Thus, complexes with symmetrical or equivalent ancillary ligands like $\left[\operatorname{Ir}\left(\kappa^{3}-\mathrm{A}_{2} \mathrm{BPN}\right)(\operatorname{cod})\right](\mathbf{3})$ and $\left[\operatorname{Ir}\left(\kappa^{3}-\mathrm{A}_{2} \mathrm{BPN}\right)(\mathrm{L})_{2}\right]\left(\mathrm{L}=\mathrm{CN}^{t} \mathrm{Bu}, \mathbf{5} ; \mathrm{CO}, 7\right)$ adopt $T B P Y-5$ structures at low temperature, but undergo a fast allyl-exchange based on a sequential coordination and de- 
coordination of both allyl groups on heating. On the contrary, this allyl-exchange was not observed for complexes with two different ligands like $\left[\operatorname{Ir}\left(\kappa^{3}-\mathrm{A}_{2} \mathrm{BPN}\right)(\mathrm{CO}) \mathrm{L}\right]\left(\mathrm{L}=\mathrm{PMe}_{3}, \mathbf{1 4}\right.$; $\mathrm{CH}_{2}=\mathrm{CH}_{2}, 17 ; \mathrm{MeO}_{2} \mathrm{CC} \equiv \mathrm{CCO}_{2} \mathrm{Me}, \mathbf{1 8}$ ), indicative of the electronic preference of the more $\pi$ accepting ligand for the equatorial position ( $\mathrm{CO}$ in 14, and the alkene/alkyne in 17 and 18). An exception was $\left[\operatorname{Ir}\left(\kappa^{3}-\mathrm{A}_{2} \mathrm{BPN}\right)(\mathrm{CO}) \mathrm{PPh}_{3}\right](\mathbf{1 3})$ for which steric effects dominate: i) placing the $\mathrm{CO}$ at the axial site and ii) producing a fast equilibrium with the less hindered square-planar isomer. The $\operatorname{Ir}(\mathrm{I})-T B P Y-5$ complexes having the CO ligand at the axial site led to, at a first glance, a 'counterintuitive' high $v(\mathrm{CO})$ stretching frecuencies, even higher than those expected for squareplanar configurations. Nonetheless, the weak $\pi$-back retrodonation from the metal to the $\mathrm{CO}$ ligand at the axial site accounts for the data, as proven from some DFT-calculations on selected examples, which result in a nice fitting between experimental and calculated $v(\mathrm{CO})$ frequencies.

The phosphane compounds $\left[\operatorname{Ir}\left(\kappa^{3}-\mathrm{A}_{2} \mathrm{BPN}\right)(\mathrm{CO}) \mathrm{PR}_{3}\right]$ are basic enough to be protonated by $\mathrm{HCl}$, in a reaction drived by the stereochemistry of the starting complexes. Direct protonation of iridium occurs for the square-planar $\mathrm{PPh}_{3}$ isomer (13), but a direct attack of the proton to the $\mathrm{H}_{2} \mathrm{C}=$ carbon in $T B P Y-5 \mathrm{PMe}_{3}$ compound (14) seem to be the most probable pathways for the syntesis of $\quad\left[\operatorname{Ir}\left(\kappa^{2}-\mathrm{A}_{2} \mathrm{BPN}\right)(\mathrm{CO})(\mathrm{Cl})(\mathrm{H}) \mathrm{PPh}_{3}\right]$ and $\left[\operatorname{Ir}\left\{\kappa^{3}\right.\right.$-(allyl)B(C $\left.\left.\left(\mathrm{CH}_{2} \mathrm{C} H C H_{3}\right)\left(\mathrm{CH}_{2} \mathrm{PPh}_{2}\right)(\mathrm{Pz})\right\}(\mathrm{Cl})(\mathrm{CO}) \mathrm{PMe}_{3}\right]$ (16), respectively. The stronger bonding to iridium of isocyanides when compared to the carbonyl ligands is probably the origin of the different reactivity of complexes $\left[\operatorname{Ir}\left(\kappa^{3}-\mathrm{A}_{2} \mathrm{BPN}\right)(\mathrm{L})_{2}\right]\left(\mathrm{L}=\mathrm{CN}^{t} \mathrm{Bu}, \mathbf{5} ; \mathrm{CO}, 7\right)$ towards dmad, which results in complexes $\left[\operatorname{Ir}\left(\kappa^{2}-\mathrm{A}_{2} \mathrm{BPN}\right)(\mathrm{CO})(\mathrm{dmad})\right](\mathbf{1 8})$ and $\left[\operatorname{Ir}\left(\kappa^{2}-\right.\right.$ $\left.\left.\mathrm{A}_{2} \mathrm{BPN}\right)\left(\mathrm{CN}^{t} \mathrm{Bu}\right)_{2}(\mathrm{dmad})\right](\mathbf{1 9})$, respectively. 


\section{Experimental Section.}

Starting Materials and Physical Methods. All the operations were carried out under an argon atmosphere using standard Schlenk techniques. Solvents were dried and distilled under argon before use by standard methods. ${ }^{42}$ Complexes $\left[\{\mathrm{Rh}(\mu-\mathrm{Cl})(\operatorname{cod})\}_{2}\right],{ }^{43}\left[\{\operatorname{Ir}(\mu-\mathrm{Cl})(\operatorname{cod})\}_{2}\right]^{44}$ and $[\operatorname{Ir}(\mathrm{acac})(\mathrm{cod})],{ }^{45}$ and compounds $[\mathrm{Li}(\mathrm{tmen})]\left[\mathrm{CH}_{2} \mathrm{PPh}_{2}\right]^{46}$ and $\left[\mathrm{B}\left(\mathrm{CH}_{2} \mathrm{CH}=\mathrm{CH}_{2}\right)_{3}\right]^{47}$ were prepared according to literature procedures. All the other chemicals used in this work have been purchased from Aldrich Chemicals and used as received. Carbon, hydrogen and nitrogen analyses were carried out with a Perkin-Elmer 2400 CHNS/O microanalyzer. FAB mass spectra were recorded in a VG Autospec double-focusing mass spectrometer. The ions were produced by the standard $\mathrm{Cs}^{+}$gun at ca. $30 \mathrm{kV}$; 3-nitrobenzyl alcohol (NBA) was used as matrix. Electrospray mass spectra (ESI-MS) were recorded in methanol on a Bruker MicroTof-Q using sodium formiate as reference. MALDI-Tof mass spectra were obtained on a Bruker Microflex mass spectrometer using DCTB (trans-2-[3-(4-tert-butylphenyl)-2-methyl-2propenylidene]malononitrile) or dithranol as matrix. NMR spectra were recorded on Bruker AV 300 and AV 400 spectrometers operating at 300.13 and $400.13 \mathrm{MHz}$, respectively, for ${ }^{1} \mathrm{H}$. Chemical shifts are reported in ppm and referenced to $\mathrm{SiMe}_{4}$, using the internal signal of the deuterated solvent as reference $\left({ }^{1} \mathrm{H},{ }^{13} \mathrm{C}\right)$ and external $\mathrm{H}_{3} \mathrm{PO}_{4}\left({ }^{31} \mathrm{P}\right)$. IR spectra in solution were recorded with a Nicolet 550 spectrophotometer using $\mathrm{NaCl}$ cells, while IR spectra of solid samples were recorded with a Perkin-Elmer 100 FT-IR Spectrometer $\left(4000-400 \mathrm{~cm}^{-1}\right)$ equipped with an ATR (Attenuated Total Reflectance).

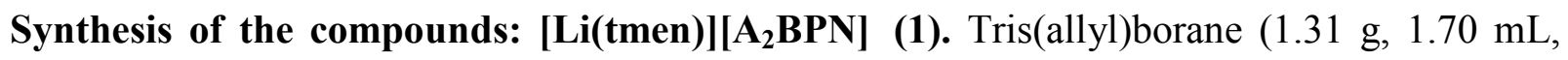
$9.80 \mathrm{mmol}$ ) was slowly added for $10 \mathrm{~min}$ via syringe to a bright yellow suspension of [Li(tmen)][ $\left.\mathrm{CH}_{2} \mathrm{PPh}_{2}\right]$ (3.17 g. $\left.9.83 \mathrm{mmol}\right)$ in toluene $(15 \mathrm{~mL})$ at room temperature. The color of 
the mixture gradually discharged to form a milky suspension, which was stirred for $40 \mathrm{~min}$. Addition of a solution of pyrazole $(0.68 \mathrm{~g}, 9.80 \mathrm{mmol})$ in toluene $(15 \mathrm{~mL})$ to the reaction mixture via cannula resulted in the precipitation of a white solid, which was dissolved upon heating at $50^{\circ} \mathrm{C}$ for one hour to give a clear colorless solution. The reaction mixture was evaporated to dryness under vacuum leaving a white oily residue that was washed with cold hexanes to afford a white solid, which was vacuum-dried. Yield: $3.07 \mathrm{~g}(65 \%)$. Anal. Calcd (\%) for $\mathrm{C}_{28} \mathrm{H}_{41} \mathrm{BLiN}_{4} \mathrm{P}$ (482.39): C 69.71, H 8.57, N 11.61; found: C 69.62, H 8.49, N 11.56. ${ }^{1} \mathrm{H}$ NMR (300 MHz, $\mathrm{C}_{6} \mathrm{D}_{6}$, $\left.25^{\circ} \mathrm{C}\right): \delta 8.10(\mathrm{~s}, 1 \mathrm{H}, \mathrm{pz}), 7.34\left(\mathrm{~m}, 4 \mathrm{H}, \mathrm{H}^{o} \mathrm{PPh}_{2}\right), 7.14\left(\mathrm{~m}, 7 \mathrm{H}, \mathrm{H}^{m+p} \mathrm{PPh}_{2}+\mathrm{pz}\right), 6.41(\mathrm{~s}, 1 \mathrm{H}, \mathrm{pz})$ $6.32(\mathrm{~m}, 2 \mathrm{H},=\mathrm{CH}), 5.16\left(\mathrm{~m}, 4 \mathrm{H},=\mathrm{CH}_{2}\right), 1.95\left(\mathrm{~d}, J=7.8 \mathrm{~Hz}, 4 \mathrm{H}, \mathrm{CH}_{2}\right.$-allyl $), 1.80\left(\mathrm{~s}, 12 \mathrm{H}, \mathrm{CH}_{3}-\right.$ tmen), $1.72\left(\mathrm{~m}, 6 \mathrm{H}, \mathrm{CH}_{2}\right.$-tmen $\left.+\mathrm{CH}_{2} \mathrm{P}\right) .{ }^{31} \mathrm{P}\left\{{ }^{1} \mathrm{H}\right\}$ NMR (121 MHz, $\left.\mathrm{C}_{6} \mathrm{D}_{6}, 25^{\circ} \mathrm{C}\right): \delta-13.6$ (br s). ${ }^{13} \mathrm{C}\left\{{ }^{1} \mathrm{H}\right\}$ NMR $\left(75 \mathrm{MHz}, \mathrm{C}_{6} \mathrm{D}_{6}, 25{ }^{\circ} \mathrm{C}\right): \delta 144.3$ (=CH-allyl), $137.6(\mathrm{pz}), 133.5(\mathrm{pz}), 132.5\left(\mathrm{~d}, J_{\mathrm{C}, \mathrm{P}}\right.$ $\left.=15 \mathrm{~Hz}, \mathrm{C}^{o} \mathrm{PPh}_{2}\right), 128.4-127.3\left(\mathrm{PPh}_{2}\right), 109.8\left(=\mathrm{CH}_{2}\right.$-allyl $), 102.7(\mathrm{pz}), 56.6\left(\mathrm{CH}_{2}\right.$-tmen $), 45.6$ ( $\mathrm{CH}_{3}$-tmen), 33.9 (br s, $\mathrm{CH}_{2}$-allyl), 22.7 (br, $\left.\mathrm{CH}_{2} \mathrm{P}\right) .{ }^{11} \mathrm{~B}\left\{{ }^{1} \mathrm{H}\right\} \mathrm{NMR}\left(96 \mathrm{MHz}, \mathrm{C}_{6} \mathrm{D}_{6}, 25{ }^{\circ} \mathrm{C}\right): \delta$ -5.89 (s). MS (MALDI-TOF $\left.{ }^{+}\right): m / z(\%): 439.1(40)\left[\mathrm{M}-\text { allyl}^{-} \mathrm{H}\right]^{+}$.

$\left[\mathbf{R h}\left(\boldsymbol{\kappa}^{2}-\mathbf{A}_{2} \mathbf{B P N}\right)(\mathbf{c o d})\right] \mathbf{( 2 )}$. Solid $\left[\{\mathrm{Rh}(\mu-\mathrm{Cl})(\operatorname{cod})\}_{2}\right](0.37 \mathrm{~g}, 0.75 \mathrm{mmol})$ was added to a solution of $1(0.72 \mathrm{~g}, 1.49 \mathrm{mmol})$ in toluene $(10 \mathrm{~mL})$. The mixture was stirred for $30 \mathrm{~min}$ to give a yellow cloudy suspension, which was filtered via cannula through a pad of celite under argon to afford a clean yellow solution. Evaporation of the solvent under vacuum gave an oily material, which was triturated with pentane to yield a yellow solid that was subsequently filtered and then vacuum-dried. Yield: $0.77 \mathrm{~g}(91 \%)$. Anal. Calcd (\%) for $\mathrm{C}_{30} \mathrm{H}_{37} \mathrm{BN}_{2} \mathrm{PRh}$ (570.33): C 63.18, $\mathrm{H}$ 6.54, N 4.91; found: C 63.08, H 6.49, N 4.87. ${ }^{1} \mathrm{H}$ NMR (300 MHz, $\left.\mathrm{C}_{6} \mathrm{D}_{6}, 25{ }^{\circ} \mathrm{C}\right): \delta 7.63(\mathrm{~m}, 4 \mathrm{H}$, $\left.\mathrm{H}^{o} \mathrm{PPh}_{2}\right), 7.59(\mathrm{~d}, J=1.7 \mathrm{~Hz}, 1 \mathrm{H}, \mathrm{pz}), 7.26(\mathrm{~d}, J=1.8 \mathrm{~Hz}, 1 \mathrm{H}, \mathrm{pz}), 7.07\left(\mathrm{~m}, 6 \mathrm{H}, \mathrm{H}^{m+p} \mathrm{PPh}_{2}\right)$, $6.36(\mathrm{~m}, 2 \mathrm{H},=\mathrm{CH}$-allyl), $5.97(\mathrm{t}, J=2.1 \mathrm{~Hz}, 1 \mathrm{H}, \mathrm{pz}), 5.43(\mathrm{dd}, J=17.0,2.9 \mathrm{~Hz}, 2 \mathrm{H})$ and 5.28 
$(\mathrm{dd}, J=10.1,3.0 \mathrm{~Hz}, 2 \mathrm{H})\left(=\mathrm{CH}_{2}\right.$-allyl $), 4.99(\mathrm{~m}, 2 \mathrm{H})$ and $3.40(\mathrm{~m}, 2 \mathrm{H})(=\mathrm{CH}-\mathrm{cod}), 2.93(\mathrm{~m}, 2 \mathrm{H}$, $\mathrm{CH}_{2}$-cod), 2.39 (m, 4H, $\mathrm{CH}_{2}$-allyl), $2.35(\mathrm{~m}, 2 \mathrm{H})$ and $1.79(\mathrm{~m}, 4 \mathrm{H})\left(\mathrm{CH}_{2}\right.$-cod), $1.68\left(\mathrm{~d}, J_{\mathrm{H}, \mathrm{P}}=\right.$ $\left.14.3 \mathrm{~Hz}, 2 \mathrm{H}, \mathrm{CH}_{2} \mathrm{P}\right) .{ }^{1} \mathrm{H}$ NMR $\left(400 \mathrm{MHz}, \mathrm{d}^{8}\right.$-toluene, $\left.-80{ }^{\circ} \mathrm{C}\right)$ : selected resonances $\delta 7.44(\mathrm{br}$, 1H, pz), 7.03(br s, 1H, pz), 6.81 (br m, 1H) and 6.05 (br m, 1H) (=CH-allyl), 5.88 (br, 1H, pz), $5.58(\mathrm{br} \mathrm{m}, 2 \mathrm{H})$ and $5.40(\mathrm{br} \mathrm{d}, J=9.9 \mathrm{~Hz}, 2 \mathrm{H}), 4.86(\mathrm{br}, 1 \mathrm{H}), 4.61(\mathrm{br}, 1 \mathrm{H}), 3.47(\mathrm{br}, 1 \mathrm{H})$ and $2.80(\mathrm{br}, 1 \mathrm{H})(=\mathrm{CH}-\mathrm{cod})$. The remaining signals were found to be too much broad for unequivocal assignment. ${ }^{31} \mathrm{P}\left\{{ }^{1} \mathrm{H}\right\}$ NMR $\left(121 \mathrm{MHz}, \mathrm{C}_{6} \mathrm{D}_{6}, 25^{\circ} \mathrm{C}\right): \delta 29.1\left(\mathrm{~d}, J_{\mathrm{P}, \mathrm{Rh}}=144 \mathrm{~Hz}\right)$. ${ }^{13} \mathrm{C}\left\{{ }^{1} \mathrm{H}\right\}$ NMR $\left(75 \mathrm{MHz}, \mathrm{C}_{6} \mathrm{D}_{6}, 25{ }^{\circ} \mathrm{C}\right): \delta 143.3$ (=CH-allyl), $138.5(\mathrm{pz}), 135.8\left(\mathrm{~d}, J_{\mathrm{C}, \mathrm{P}}=39 \mathrm{~Hz}\right.$, $\left.\mathrm{C}^{i} \mathrm{PPh}_{2}\right), 134.9(\mathrm{pz}), 133.0\left(\mathrm{~d}, J_{\mathrm{C}, \mathrm{P}}=10 \mathrm{~Hz}, \mathrm{C}^{o} \mathrm{PPh}_{2}\right), 129.2\left(\mathrm{~d}, J_{\mathrm{C}, \mathrm{P}}=2 \mathrm{~Hz}, \mathrm{C}^{m} \mathrm{PPh}_{2}\right), 127.9\left(\mathrm{C}^{p}\right.$ $\left.\mathrm{PPh}_{2}\right), 110.6\left(=\mathrm{CH}_{2}\right.$-allyl), $104.5(\mathrm{pz}), 101.1\left(\mathrm{dd}, J_{\mathrm{C}, \mathrm{P}}=13 \mathrm{~Hz}, J_{\mathrm{C}, \mathrm{Rh}}=11 \mathrm{~Hz}\right)$ and $72.5\left(\mathrm{~d}, J_{\mathrm{C}, \mathrm{Rh}}=\right.$ $12 \mathrm{~Hz})\left(=\mathrm{CH}\right.$-cod), 35.0 (br, $\mathrm{CH}_{2}$-allyl), 32.4 and $28.8\left(\mathrm{CH}_{2}\right.$-cod), 19.8 (br, $\left.\mathrm{CH}_{2} \mathrm{P}\right) . \mathrm{MS}$ (MALDI-TOF $\left.{ }^{+}\right): m / z(\%): 529.2(100)\left[\mathrm{M}^{-} \text {allyl }\right]^{+}$.

$\left[\operatorname{Ir}\left(\kappa^{3}-\mathbf{A}_{2} \mathbf{B P N}\right)(\mathbf{c o d})\right] \mathbf{( 3 )}$. Solid $[\operatorname{Ir}(\mathrm{acac})(\mathrm{cod})](0.20 \mathrm{~g}, 0.50 \mathrm{mmol})$ was added to a white suspension of $1(0.24 \mathrm{~g}, 0.50 \mathrm{mmol})$ in diethyl ether $(10 \mathrm{~mL})$. The mixture was stirred for $30 \mathrm{~min}$ to form a suspension, which was filtered via cannula through a pad of celite under argon to afford a clean pale-orange solution. Evaporation of the solvent under vacuum gave an orange solid, which was recrystallized from dichloromethane-hexane. Yield: $0.27 \mathrm{~g}(81 \%)$. Starting from $\left[\{\operatorname{Ir}(\mu-\mathrm{Cl})(\operatorname{cod})\}_{2}\right]$ : To a white suspension of $1(0.13 \mathrm{~g}, 0.28 \mathrm{mmol})$ in toluene $(10 \mathrm{~mL})$ solid $\left[\{\operatorname{Ir}(\mu-\mathrm{Cl})(\operatorname{cod})\}_{2}(0.09 \mathrm{~g}, 0.14 \mathrm{mmol})\right.$ was added. The mixture was stirred for 1 hour and passed through a pad of cellite to remove the solid. The resulting solution was evaporated to dryness and the resulting orange oil was treated with cold hexanes to afford an orange solid, which was then filtered out and dried by vacuum. Yield: $0.12 \mathrm{~g}(68 \%)$. Anal. Calcd (\%) for $\mathrm{C}_{30} \mathrm{H}_{37} \mathrm{BIrN}_{2} \mathrm{P}$ (659.64): C 54.63, H 5.65, N 4.25; found: C 54.59, H 5.59, N 4.18. ${ }^{1} \mathrm{H}$ NMR (400 MHz, $\mathrm{d}_{8-}$ 
toluene, $\left.100{ }^{\circ} \mathrm{C}\right): \delta 7.59(\mathrm{br} \mathrm{s}, 1 \mathrm{H}, \mathrm{pz}), 7.41\left(\mathrm{~m}, 4 \mathrm{H}, \mathrm{PPh}_{2}\right), 7.08\left(\mathrm{~m}, 6 \mathrm{H}, \mathrm{PPh}_{2}\right), 6.70(\mathrm{br} \mathrm{s}, 1 \mathrm{H})$ and $5.82(\mathrm{br} \mathrm{s}, 1 \mathrm{H})(\mathrm{pz}), 4.94(\mathrm{br} \mathrm{s}, 2 \mathrm{H},=\mathrm{CH}-$ allyl), $4.49(\mathrm{~d}, J=9.5 \mathrm{~Hz}, 2 \mathrm{H})$ and $3.74(\mathrm{~d}, J=14.3$ $\mathrm{Hz}, 2 \mathrm{H})\left(=\mathrm{CH}_{2}\right.$-allyl), 3.4-2.4 (flat, 4H, =CH-cod), 2.12 (m, 4H, $\mathrm{CH}_{2}$-cod), 1.72 (br m, 4H, $\mathrm{CH}_{2}-$ cod), 1.63 (br m, 4H, $\mathrm{CH}_{2}$-allyl), $1.15\left(J=12.6 \mathrm{~Hz}, 2 \mathrm{H}, \mathrm{CH}_{2} \mathrm{P}\right) .{ }^{1} \mathrm{H}$ NMR (400 MHz, d8-toluene, $\left.-80{ }^{\circ} \mathrm{C}\right): \delta 7.61$ (br, 1H, pz), $7.27\left(\mathrm{~m}, 2 \mathrm{H}, \mathrm{H}^{o} \mathrm{PPh}_{2}\right), 7.14\left(\mathrm{~m}, 3 \mathrm{H}, \mathrm{H}^{m+p} \mathrm{PPh}_{2}\right), 7.08\left(\mathrm{~m}, 2 \mathrm{H}, \mathrm{H}^{m}\right.$ $\left.\mathrm{PPh}_{2}\right), 6.99\left(\mathrm{~m}, 1 \mathrm{H}, \mathrm{H}^{p} \mathrm{PPh}_{2}\right), 6.95\left(\mathrm{~m}, 2 \mathrm{H}, \mathrm{H}^{o} \mathrm{PPh}_{2}\right), 6.61$ (br, 1H, pz), 6.45 (m, 1H, =CH-allyl), $5.87(\mathrm{br}, 1 \mathrm{H}, \mathrm{pz}), 5.31(\mathrm{~d}, J=16.9 \mathrm{~Hz}, 1 \mathrm{H})$ and $5.21(\mathrm{~d}, \mathrm{~J}=16.9 \mathrm{~Hz}, 1 \mathrm{H})\left(=\mathrm{CH}_{2}\right.$-allyl), $3.92(\mathrm{~d}, J$ $=4.9 \mathrm{~Hz}, 1 \mathrm{H},=\mathrm{CH}_{2}-\eta^{2}$-allyl $), 3.70(\mathrm{~s}, 1 \mathrm{H},=\mathrm{CH}-\mathrm{cod}), 3,60\left(\mathrm{~m}, 2 \mathrm{H},=\mathrm{CH}-\mathrm{cod}+=\mathrm{CH}-\eta^{2}\right.$-allyl $)$, $2.91(\mathrm{~s}, 1 \mathrm{H},=\mathrm{CH}-\mathrm{cod}), 2.25\left(\mathrm{~m}, 2 \mathrm{H}, \mathrm{CH}_{2}-\mathrm{cod}\right), 2.10\left(\mathrm{~m}, 2 \mathrm{H},=\mathrm{CH}_{2}-\eta^{2}\right.$-allyl $+\mathrm{CH}_{2}-\eta^{2}$-allyl), 1.97 (m, 2H, CH 2 -allyl), 1.88 (m, 1H, $\mathrm{CH}_{2}$-cod), 1.72 (m, 1H, $\mathrm{CH}_{2}$ - $\eta^{2}$-allyl, 1.64 (m, 1H, $\left.\mathrm{CH}_{2} \mathrm{P}\right), 1.60$ (m, 2H, $\left.\mathrm{CH}_{2}-\mathrm{cod}+=\mathrm{CH}-\mathrm{cod}\right), 1.56\left(\mathrm{~m}, 1 \mathrm{H}, \mathrm{CH}_{2}-\mathrm{cod}\right), 1.37(\mathrm{~m}, 1 \mathrm{H}), 1.09\left(\mathrm{~m}, 2 \mathrm{H}, \mathrm{CH}_{2} \operatorname{cod}\right)$, 0.73 (m, 1H, $\left.\mathrm{CH}_{2} \mathrm{P}\right) .{ }^{31} \mathrm{P}\left\{{ }^{1} \mathrm{H}\right\} \mathrm{NMR}\left(161 \mathrm{MHz}, \mathrm{C}_{6} \mathrm{D}_{6}, 25{ }^{\circ} \mathrm{C}\right): \delta$ 1.6. ${ }^{13} \mathrm{C}\left\{{ }^{1} \mathrm{H}\right\}$ NMR (100 MHz, $\mathrm{d}_{8}$-toluene, $\left.-80^{\circ} \mathrm{C}\right): \delta 143.6(=\mathrm{CH}$-allyl $), 142.6\left(\mathrm{~d}, J_{\mathrm{P}, \mathrm{C}}=35 \mathrm{~Hz}\right)$ and $138.8\left(\mathrm{~d}, J_{\mathrm{P}, \mathrm{C}}=40 \mathrm{~Hz}\right)\left(\mathrm{C}^{i}\right.$ $\mathrm{PPh}_{2}$ ), 134.9 and $133.6(\mathrm{pz}), 133.4\left(\mathrm{~d}, J_{\mathrm{P}, \mathrm{C}}=8 \mathrm{~Hz}, \mathrm{C}^{o} \mathrm{PPh}_{2}\right), 130.8$ (d, $J_{\mathrm{P}, \mathrm{C}}=9 \mathrm{~Hz}, \mathrm{C}^{m} \mathrm{PPh}_{2}$ ), 129.6 ( $\left.\mathrm{C}^{p} \mathrm{PPh}_{2}\right), 128.3\left(\mathrm{~m}, \mathrm{C}^{o+m+p} \mathrm{PPh}_{2}\right), 110.9\left(=\mathrm{CH}_{2}\right.$-allyl), 104.5 (pz), 75.1, 70.7 and $64.9(\mathrm{~d}$, $\left.J_{\mathrm{P}, \mathrm{C}}=6 \mathrm{~Hz}\right)(=\mathrm{CH}-\mathrm{cod}), 63.1\left(\mathrm{~d}, J_{\mathrm{P}, \mathrm{C}}=7 \mathrm{~Hz},=\mathrm{CH}-\eta^{2}\right.$-allyl $), 58.8\left(\mathrm{~d}, J_{\mathrm{P}, \mathrm{C}}=21 \mathrm{~Hz},=\mathrm{CH}-\mathrm{cod}\right)$, $47.3\left(\mathrm{~d}, J_{\mathrm{P}, \mathrm{C}}=8 \mathrm{~Hz},=\mathrm{CH}_{2}-\eta^{2}\right.$-allyl), 35.2 (br m, $\mathrm{CH}_{2}$-allyl), 34.8 (br m, $\mathrm{CH}_{2}-\eta^{2}$-allyl), 31.9, 31.4, 30.6, and $30.4\left(\mathrm{CH}_{2}\right.$-cod), 20.2 (br m, $\left.\mathrm{CH}_{2} \mathrm{P}\right) .{ }^{11} \mathrm{~B}\left\{{ }^{1} \mathrm{H}\right\}$ NMR (96 MHz, $\mathrm{CDCl}_{3}, 25{ }^{\circ} \mathrm{C}$ ): $\delta 0.55$ (br s). MS (MALDI-TOF $\left.{ }^{+}\right): m / z(\%): 619.1(100)[\text { M-allyl }]^{+}$.

$\left[\mathbf{R h}\left(\boldsymbol{\kappa}^{2}-\mathbf{A}_{2} \mathbf{B P N}\right)\left(\mathbf{C N}^{t} \mathbf{B u}\right)_{2}\right] \mathbf{( 4 )}$. To a yellow solution of $\mathbf{2}(0.12 \mathrm{~g}, 0.21 \mathrm{mmol})$ in diethyl ether (10 mL), $\mathrm{CN}^{t} \mathrm{Bu}(39 \mathrm{mg}, 53 \mu \mathrm{l}, 0.47 \mathrm{mmol})$ was slowly added via syringe and the resulting mixture was stirred for $30 \mathrm{~min}$ at room temperature. The solution was concentrated under vacuum to ca. $2 \mathrm{~mL}$ and a further addition of hexanes gave a light orange oil. This was 
redissolved in diethyl ether and further addition of hexanes afforded a yellow powder which was isolated by filtration and then vacuum-dried. Yield: $0.11 \mathrm{~g}(86 \%)$. Anal. Calcd (\%) for $\mathrm{C}_{32} \mathrm{H}_{43} \mathrm{BN}_{4} \mathrm{PRh}$ (628.41): C 61.16, H 6.90, N 8.92; found: C 61.09, H 6.80, N 8.81. IR (toluene): $v(\mathrm{CN}) / \mathrm{cm}^{-1}: 2159$ (s), $2114(\mathrm{~s}) .{ }^{1} \mathrm{H}$ NMR $\left(300 \mathrm{MHz}, \mathrm{C}_{6} \mathrm{D}_{6}, 25^{\circ} \mathrm{C}\right): \delta 7.91\left(\mathrm{~m}, 4 \mathrm{H}, \mathrm{H}^{o} \mathrm{PPh}_{2}+1 \mathrm{H}\right.$ ,pz), 7.80 (d, $J=1.8 \mathrm{~Hz}, 1 \mathrm{H}, \mathrm{pz}), 7.09$ (m, 6H, $\mathrm{H}^{m+p} \mathrm{PPh}_{2}$ ), 6.39 (m, 2H, =CH-allyl), 6.14 (t, $J=$ $2.1 \mathrm{~Hz}, 1 \mathrm{H}, \mathrm{pz}), 5.22(\mathrm{dd}, J=16.8,3.3 \mathrm{~Hz}, 2 \mathrm{H})$ and $5.08(\mathrm{dd}, J=12.6,3.3 \mathrm{~Hz}, 2 \mathrm{H})\left(=\mathrm{CH}_{2}\right.$-allyl), $2.86(\mathrm{~m}, 2 \mathrm{H})$ and $2.13(\mathrm{~m}, 2 \mathrm{H})\left(\mathrm{CH}_{2}\right.$-allyl $), 1.58\left(\mathrm{~d}, J_{\mathrm{H}, \mathrm{P}}=13.2 \mathrm{~Hz}, 2 \mathrm{H}, \mathrm{CH}_{2} \mathrm{P}\right), 1.99(\mathrm{~s}, 9 \mathrm{H})$ and $0.86(\mathrm{~s}, 9 \mathrm{H})\left(\mathrm{CN}^{t} \mathrm{Bu}\right) .{ }^{31} \mathrm{P}\left\{{ }^{1} \mathrm{H}\right\} \operatorname{NMR}\left(121 \mathrm{MHz}, \mathrm{C}_{6} \mathrm{D}_{6}, 25{ }^{\circ} \mathrm{C}\right): \delta 28.2\left(\mathrm{~d}, J_{\mathrm{P}, \mathrm{Rh}}=130 \mathrm{~Hz}\right)$. ${ }^{13} \mathrm{C}\left\{{ }^{1} \mathrm{H}\right\}$ NMR (75 MHz, $\left.\mathrm{C}_{6} \mathrm{D}_{6}, 25{ }^{\circ} \mathrm{C}\right): \delta 144.0$ (=CH-allyl), $142.5(\mathrm{pz}), 139.9\left(\mathrm{~d}, J_{\mathrm{C}, \mathrm{P}}=39 \mathrm{~Hz}\right.$, $\left.\mathrm{C}^{i} \mathrm{PPh}_{2}\right), 134.0(\mathrm{pz}), 133.5\left(\mathrm{~d}, J_{\mathrm{C}, \mathrm{P}}=12 \mathrm{~Hz}, \mathrm{C}^{o} \mathrm{PPh}_{2}\right), 128.5\left(\mathrm{~d}, J_{\mathrm{C}, \mathrm{P}}=2 \mathrm{~Hz}, \mathrm{C}^{m} \mathrm{PPh}_{2}\right), 127.7\left(\mathrm{C}^{p}\right.$ $\left.\mathrm{PPh}_{2}\right), 109.5$ (=CH $\left(\mathrm{CMe}_{3}\right), 20.6$ (br s, $\left.\mathrm{CH}_{2} \mathrm{P}\right)$. MS (MALDI-TOF ${ }^{+}$): $m / z(\%): 586.2$ (10) [M-allyl] ${ }^{+}$.

$\left[\mathbf{I r}\left(\kappa^{3}-\mathbf{A}_{2} \mathbf{B P N}\right)\left(\mathbf{C N}^{t} \mathbf{B u}\right)_{2}\right]$ (5). To a solution of $\mathbf{3}(0.10 \mathrm{~g}, 0.15 \mathrm{mmol})$ in dietyl ether $(7 \mathrm{~mL})$, $\mathrm{CN}^{t} \mathrm{Bu}(39 \mu 1,0.34 \mathrm{mmol})$ was added dropwise via syringe. The colour of the solution changed rapidly to orange and 20 minutes after the reaction mixture was evaporated to dryness affording an orange oily residue. Addition of cold hexanes gave a white solid, which was filtered off and then dried under vacuum. Yield: $0.094 \mathrm{~g}(87 \%)$. Anal. Calcd (\%) for $\mathrm{C}_{32} \mathrm{H}_{43} \mathrm{BIrN}_{4} \mathrm{P}$ (717.72): $\mathrm{C}$ 53.55, H 6.04, N 7.81; found: C 53.48, H 5.95, N 7.67. IR (toluene): $v(\mathrm{CN}) / \mathrm{cm}^{-1}: 2085$ (s), 2043 (s). ${ }^{1} \mathrm{H}$ NMR (300 MHz, $\mathrm{d}_{8}$-toluene, $\left.-50{ }^{\circ} \mathrm{C}\right): \delta 8.05(\mathrm{~s}, 1 \mathrm{H}, \mathrm{pz}), 7.74(\mathrm{~m}, 2 \mathrm{H})$ and $7.63(\mathrm{~m}, 2 \mathrm{H})$ $\left(\mathrm{H}^{o} \mathrm{PPh}_{2}\right), 7.43$ (s, 1H, pz), $7.00\left(\mathrm{~m}, 6 \mathrm{H}, \mathrm{H}^{m+p} \mathrm{PPh}_{2}\right), 6.88$ (m, 1H, =CH-allyl), 6.03 (s, 1H, pz), $5.53(\mathrm{~d}, J=17.0 \mathrm{~Hz}, 1 \mathrm{H})$ and $5.45(\mathrm{~d}, J=12.0 \mathrm{~Hz}, 1 \mathrm{H})\left(=\mathrm{CH}_{2}\right.$-allyl $), 3.26\left(\mathrm{~m}, 1 \mathrm{H},=\mathrm{CH}_{2}\right), 3.10$ $(\mathrm{m}, 1 \mathrm{H},=\mathrm{CH})$ and $\left(\mathrm{m}, 1 \mathrm{H},=\mathrm{CH}_{2}+1 \mathrm{H}, \mathrm{CH}_{2}\right)\left(\eta^{2}\right.$-allyl $), 2.22\left(\mathrm{~m}, 2 \mathrm{H}, \mathrm{CH}_{2}\right.$-allyl $\left.+1 \mathrm{H}, \mathrm{CH}_{2} \mathrm{P}\right)$, $1.31\left(\mathrm{~m}, 1 \mathrm{H}, \mathrm{CH}_{2}-\eta^{2}\right.$-allyl $\left.+1 \mathrm{H}, \mathrm{CH}_{2} \mathrm{P}\right), 1.01(\mathrm{~s}, 9 \mathrm{H})$ and $0.46(\mathrm{~s}, 9 \mathrm{H})\left(\mathrm{CN}^{t} \mathrm{Bu}\right) .{ }^{31} \mathrm{P}\left\{{ }^{1} \mathrm{H}\right\} \mathrm{NMR}$ 
(121 MHz, $\mathrm{d}_{8}$-toluene, $\left.25{ }^{\circ} \mathrm{C}\right): \delta 0.0 .{ }^{13} \mathrm{C}\left\{{ }^{1} \mathrm{H}\right\}$ NMR (75 MHz, $\mathrm{d}_{8}$-toluene, $\left.-50{ }^{\circ} \mathrm{C}\right): \delta 144.6$ $(=\mathrm{CH}-\mathrm{allyl}), 142.7\left(\mathrm{~d}, J_{\mathrm{P}, \mathrm{C}}=36 \mathrm{~Hz}\right)$ and $141.6\left(\mathrm{~d}, J_{\mathrm{C}, \mathrm{P}}=25 \mathrm{~Hz}\right)\left(C \mathrm{~N}^{t} \mathrm{Bu}\right), 141.1(\mathrm{pz}), 137.3(\mathrm{~d}$, $\left.J_{\mathrm{C}, \mathrm{P}}=43 \mathrm{~Hz}\right)$ and $137.3\left(\mathrm{~d}, J_{\mathrm{C}, \mathrm{P}}=49 \mathrm{~Hz}\right)\left(\mathrm{C}^{i} \mathrm{PPh}_{2}\right), 133.7\left(\mathrm{~d}, J_{\mathrm{C}, \mathrm{P}}=13 \mathrm{~Hz}, \mathrm{C}^{o} \mathrm{PPh}_{2}\right), 131.4(\mathrm{pz})$, $131.1\left(\mathrm{~d}, J_{\mathrm{C}, \mathrm{P}}=10 \mathrm{~Hz}, \mathrm{C}^{o} \mathrm{PPh}_{2}\right), 128\left(\mathrm{~m}, \mathrm{C}^{m+p} \mathrm{PPh}_{2}\right), 110.4$ (=CH $55.9\left(\mathrm{CMe}_{3}\right), 40.0\left(\mathrm{~d}, J_{\mathrm{P}, \mathrm{C}}=6 \mathrm{~Hz},=\mathrm{CH}-\eta^{2}\right.$-allyl), $35.2\left(\mathrm{br}, \mathrm{CH}_{2}\right.$-allyl), $30.9\left(\mathrm{~d}, J_{\mathrm{P}, \mathrm{C}}=25 \mathrm{~Hz}\right.$, $=\mathrm{CH}_{2}-\eta^{2}$-allyl), 30.2 and $29.9\left(\mathrm{CMe}_{3}\right), 24.9\left(\mathrm{br}, \mathrm{CH}_{2}-\eta^{2}\right.$-allyl), $21.4\left(\mathrm{br}, \mathrm{CH}_{2} \mathrm{P}\right)$. MS (MALDITOF $\left.^{+}\right): m / z(\%): 719.2(5)[\mathrm{M}-\mathrm{H}]^{+}, 677.2(100)\left[\mathrm{M}^{-} \text {allyl }\right]^{+}$.

$\left[\mathbf{R h}\left(\boldsymbol{\kappa}^{2}-\mathrm{A}_{2} \mathbf{B P N}\right)(\mathbf{C O})_{2}\right] \mathbf{( 6 )}$. A solution of $2(0.02 \mathrm{~g}, 0.03 \mathrm{mmol})$ in $\mathrm{d}_{8}$-toluene $(0.4 \mathrm{~mL})$ was shaken with carbon monoxide for 10 min to give a clear yellow solution. NMR monitoring of the sample showed a clean and quantitative conversion to 6. IR (toluene): $v(\mathrm{CO}) / \mathrm{cm}^{-1}: 2077$ (s), 2018 (s); (cyclohexane) $v(\mathrm{CO}) / \mathrm{cm}^{-1}: 2083$ (s), 2020 (s). ${ }^{1} \mathrm{H}$ NMR (300 MHz, d8-toluene, -50 $\left.{ }^{\circ} \mathrm{C}\right): \delta 7.38\left(\mathrm{dd}, J=6.7,3.1 \mathrm{~Hz}, 2 \mathrm{H}, \mathrm{H}^{o} \mathrm{PPh}_{2}\right), 7.35(\mathrm{~d}, J=2.2 \mathrm{~Hz}, 1 \mathrm{H}, \mathrm{pz}), 7.32(\mathrm{dd}, J=6.2,3.1$ $\left.\mathrm{Hz}, 2 \mathrm{H}, \mathrm{H}^{o} \mathrm{PPh}_{2}\right), 7.14$ (br, 1H, pz), $6.90\left(\mathrm{~m}, 6 \mathrm{H}, \mathrm{H}^{m+p} \mathrm{PPh}_{2}\right.$ ), 6.11 (ddd, J=17.3, 14.9, 7.1 Hz, 2H, =CH-allyl), $5.74(\mathrm{t}, J=2.2 \mathrm{~Hz}, 1 \mathrm{H}, \mathrm{pz}), 5.00(\mathrm{br}, 2 \mathrm{H})$ and $4.96(\mathrm{~m}, 2 \mathrm{H})\left(=\mathrm{CH}_{2}\right.$-allyl), 2.28 $(\mathrm{dd}, J=12.2,7.7 \mathrm{~Hz}, 2 \mathrm{H})$ and $1.78(\mathrm{dd}, J=12.0,8.4 \mathrm{~Hz}, 2 \mathrm{H})\left(\mathrm{CH}_{2}\right.$-allyl), $1.50\left(\mathrm{~d}, J_{\mathrm{H}, \mathrm{P}}=14.9\right.$ $\left.\mathrm{Hz}, 2 \mathrm{H}, \mathrm{CH}_{2} \mathrm{P}\right) .{ }^{31} \mathrm{P}\left\{{ }^{1} \mathrm{H}\right\}$ NMR $\left(121 \mathrm{MHz}, \mathrm{d}_{8}\right.$-toluene, $\left.25{ }^{\circ} \mathrm{C}\right): \delta 30.9\left(\mathrm{~d}, J_{\mathrm{P}, \mathrm{Rh}}=120 \mathrm{~Hz}\right) .{ }^{13} \mathrm{C}\left\{{ }^{1} \mathrm{H}\right\}$

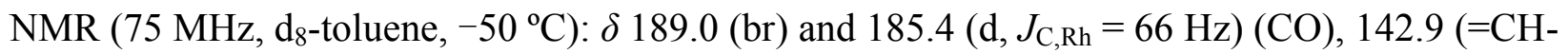
allyl), 141.8 (pz), 135.8 (d, $\left.J=45 \mathrm{~Hz}, \mathrm{C}^{i} \mathrm{PPh}_{2}\right), 134.7$ (pz), 132.4 (d, $\left.J=11 \mathrm{~Hz}, \mathrm{C}^{o} \mathrm{PPh}_{2}\right), 130.0$ (d, $\left.J=2 \mathrm{~Hz}, \mathrm{C}^{p} \mathrm{PPh}_{2}\right), 128.5$ (d, $J=10 \mathrm{~Hz}, \mathrm{C}^{m} \mathrm{PPh}_{2}$ ), 105.3 (= $\mathrm{CH}_{2}$-allyl), 104.5 (pz), 34.3 (br, $\mathrm{CH}_{2}$-allyl), 19.1 (br, $\left.\mathrm{CH}_{2} \mathrm{P}\right)$. MS (MALDI-TOF $\left.{ }^{+}\right): m / z(\%): 517.3$ (2) [M-H] $]^{+}$.

$\left[\operatorname{Ir}\left(\kappa^{3}-\mathbf{A}_{2} \mathbf{B P N}\right)(\mathbf{C O})_{2}\right](\mathbf{7})$ was prepared as described for $\mathbf{6}$ starting from a solution of $\mathbf{3}(0.03 \mathrm{~g}$, $0.05 \mathrm{mmol}$ ) in $\mathrm{CD}_{2} \mathrm{Cl}_{2}(0.4 \mathrm{~mL})$. IR (diethyl ether): $v(\mathrm{CO}) / \mathrm{cm}^{-1}: 2053$ (s), 1986 (s); (cyclohexane) $v(\mathrm{CO}) / \mathrm{cm}^{-1}: 2053$ (s), $1982(\mathrm{~s}) .{ }^{1} \mathrm{H}$ NMR $\left(300 \mathrm{MHz}, \mathrm{CD}_{2} \mathrm{Cl}_{2},-55^{\circ} \mathrm{C}\right): \delta 7.57(\mathrm{~s}$, 
1H, pz), 7.51-7.34 (m, 10H, $\left.\mathrm{PPh}_{2}\right), 7.22(\mathrm{~s}, 1 \mathrm{H}, \mathrm{pz}), 6.04$ (m, 1H, =CH-allyl), $5.96(\mathrm{~s}, 1 \mathrm{H}, \mathrm{pz})$ $4.84(\mathrm{~d}, J=17.4 \mathrm{~Hz}, 1 \mathrm{H})$ and $4.77(\mathrm{~d}, J=10.0 \mathrm{~Hz}, 1 \mathrm{H})\left(=\mathrm{CH}_{2}\right.$ allyl $), 3.56(\mathrm{~m}, 1 \mathrm{H},=\mathrm{CH}), 3.35$ $\left(\mathrm{m}, 1 \mathrm{H},=\mathrm{CH}_{2}\right)$ and $1.96\left(\mathrm{~m}, 1 \mathrm{H},=\mathrm{CH}_{2}\right)\left(\eta^{2}\right.$-allyl $), 1.62\left(\mathrm{~m}, 1 \mathrm{H}, \mathrm{CH}_{2} \mathrm{P}\right), 1.60\left(\mathrm{~m}, 1 \mathrm{H}, \mathrm{CH}_{2}\right.$-allyl $)$, $1.57\left(\mathrm{~m}, 1 \mathrm{H}, \mathrm{CH}_{2}-\eta^{2}\right.$-allyl), $1.44\left(\mathrm{~m}, 1 \mathrm{H}, \mathrm{CH}_{2}\right.$-allyl), $1.35\left(\mathrm{~m}, 1 \mathrm{H}, \mathrm{CH}_{2} \mathrm{P}\right), 0.20\left(\mathrm{~m}, 1 \mathrm{H}, \mathrm{CH}_{2}-\eta^{2}-\right.$ allyl). ${ }^{31} \mathrm{P}\left\{{ }^{1} \mathrm{H}\right\}$ NMR (121 MHz, $\left.\mathrm{CD}_{2} \mathrm{Cl}_{2}, 25{ }^{\circ} \mathrm{C}\right): \delta-0.6 .{ }^{13} \mathrm{C}\left\{{ }^{1} \mathrm{H}\right\}$ NMR $\left(75 \mathrm{MHz}, \mathrm{CD}_{2} \mathrm{Cl}_{2},-55\right.$ $\left.{ }^{\circ} \mathrm{C}\right): \delta 184.6\left(\mathrm{~d}, J_{\mathrm{C}, \mathrm{P}}=17 \mathrm{~Hz}\right)$ and $166.8\left(\mathrm{~d}, J_{\mathrm{C}, \mathrm{P}}=5 \mathrm{~Hz}\right)(\mathrm{CO}), 143.8(\mathrm{pz}), 143.1(=\mathrm{CH}-$ allyl$)$, $137.6\left(\mathrm{~d}, J_{\mathrm{C}, \mathrm{P}}=43 \mathrm{~Hz}\right)$ and $135.4\left(\mathrm{~d}, J_{\mathrm{C}, \mathrm{P}}=43 \mathrm{~Hz}\right)\left(\mathrm{C}^{i} \mathrm{PPh}_{2}\right), 132.8(\mathrm{pz}), 132.4\left(\mathrm{~d}, J_{\mathrm{C}, \mathrm{P}}=12 \mathrm{~Hz}\right)$ and $130.4\left(\mathrm{~d}, J_{\mathrm{C}, \mathrm{P}}=11 \mathrm{~Hz}\right)\left(\mathrm{C}^{o} \mathrm{PPh}_{2}\right), 128.5\left(\mathrm{~m}, \mathrm{C}^{m+p} \mathrm{PPh}_{2}\right), 110.7\left(=\mathrm{CH}_{2}\right.$-allyl $), 106.1(\mathrm{pz}), 53.8$ (br, $=\mathrm{CH}-\eta^{2}$-allyl), $36.6\left(\mathrm{~d}, J_{\mathrm{C}, \mathrm{P}}=16 \mathrm{~Hz},=\mathrm{CH}_{2}-\eta^{2}\right.$-allyl), 33.9 (br, $\mathrm{CH}_{2}$-allyl), 24.4 (br, $\mathrm{CH}_{2}-\eta^{2}-$ allyl), 16.8 (br, $\left.\mathrm{CH}_{2} \mathrm{P}\right)$. MS (MALDI-TOF $\left.{ }^{+}\right): m / z(\%): 607.1$ (100) [M] $]^{+}$.

$\left[\left\{\mathbf{R h}\left(\mathbf{A}_{2} \mathbf{B P N}\right)(\mathbf{C O})\right\}_{2}\right] \mathbf{( 8 )}$. A solution of $\mathbf{2}(0.15 \mathrm{~g}, 0.26 \mathrm{mmol})$ in diethyl ether $(20 \mathrm{~mL})$ was bubbled with carbon monoxide for $30 \mathrm{~min}$ to give an orange solution. The volume of the reaction mixture was reduced to ca. $5 \mathrm{~mL}$ under vacuum and then hexanes were added slowly to facilitate the precipitation of a bright yellow solid, which was filtered, washed with cold hexanes and then dried under vacuum. Yield: $0.11 \mathrm{~g}(85 \%)$. Anal. Calcd (\%) for $\mathrm{C}_{46} \mathrm{H}_{50} \mathrm{~B}_{2} \mathrm{~N}_{4} \mathrm{O}_{2} \mathrm{P}_{2} \mathrm{Rh}_{2}$ (908.31): C 56.36, H 5.14, N 5.72; found: C 56.28, H 5.02, N 5.68. IR (toluene): $v(\mathrm{CO}) / \mathrm{cm}^{-1}: 1995$ (s). ${ }^{1} \mathrm{H}$ NMR (300 MHz, $\left.\mathrm{C}_{6} \mathrm{D}_{6}, 25^{\circ} \mathrm{C}\right): \delta 7.55\left(\mathrm{~m}, 8 \mathrm{H}, \mathrm{H}^{o} \mathrm{PPh}_{2}\right), 7.32(\mathrm{~d}, J=2.3 \mathrm{~Hz}, 2 \mathrm{H}, \mathrm{pz}), 6.91(\mathrm{~m}$, 12H, $\mathrm{H}^{m+p} \mathrm{PPh}_{2}$ ), 6.71 (d, $\left.J=1.9 \mathrm{~Hz}, 2 \mathrm{H}, \mathrm{pz}\right), 6.33$ (dq, $J=17.2,8.3 \mathrm{~Hz}, 2 \mathrm{H},=\mathrm{CH}-$ allyl), 5.60 (t, $J=2.5 \mathrm{~Hz}, 2 \mathrm{H}, \mathrm{pz}), 5.24(\mathrm{dd}, J=16.9,2.9 \mathrm{~Hz}, 2 \mathrm{H})$ and $5.13(\mathrm{dd}, J=10.0,2.8 \mathrm{~Hz}, 2 \mathrm{H})\left(=\mathrm{CH}_{2}-\right.$ allyl), $4.98\left(\mathrm{br}, 2 \mathrm{H},=\mathrm{CH}-\eta^{2}\right.$-allyl $+2 \mathrm{H},=\mathrm{CH}_{2}-\eta^{2}$-allyl), $4.77\left(\mathrm{~d}, J=11.0 \mathrm{~Hz}, 2 \mathrm{H}, \mathrm{CH}_{2}-\eta^{2}\right.$-allyl), $4.45\left(\mathrm{~d}, J=5.6 \mathrm{~Hz}, 2 \mathrm{H},=\mathrm{CH}_{2}-\eta^{2}\right.$-allyl), 2.09 (t, $J=10.5 \mathrm{~Hz}, 2 \mathrm{H}, \mathrm{CH}_{2}-\eta^{2}$-allyl), 1.95 (m, 2H) and $1.84(\mathrm{~m}, 2 \mathrm{H})\left(\mathrm{CH}_{2}\right.$-allyl), $1.72(\mathrm{t}, J=15.2 \mathrm{~Hz}, 2 \mathrm{H})$ and $1.57(\mathrm{t}, J=13.7 \mathrm{~Hz}, 2 \mathrm{H})\left(\mathrm{CH}_{2} \mathrm{P}\right)$. ${ }^{31} \mathrm{P}\left\{{ }^{1} \mathrm{H}\right\}$ NMR $\left(121 \mathrm{MHz}, \mathrm{C}_{6} \mathrm{D}_{6}, 25{ }^{\circ} \mathrm{C}\right): \delta 30.6\left(\mathrm{~d}, J_{\mathrm{P}-\mathrm{Rh}}=150 \mathrm{~Hz}\right) .{ }^{13} \mathrm{C}\left\{{ }^{1} \mathrm{H}\right\} \mathrm{NMR}(75 \mathrm{MHz}$, 
$\left.\mathrm{C}_{6} \mathrm{D}_{6}, 25^{\circ} \mathrm{C}\right): \delta 192.1\left(\mathrm{dd}, J_{\mathrm{C}, \mathrm{Rh}}=71 \mathrm{~Hz}, J_{\mathrm{C}, \mathrm{P}}=14 \mathrm{~Hz}, \mathrm{CO}\right), 142.1(=\mathrm{CH}-\mathrm{allyl}), 138.7\left(\mathrm{dd}, J_{\mathrm{C}, \mathrm{P}}=\right.$ 46, $\left.3 \mathrm{~Hz}, \mathrm{C}^{i} \mathrm{PPh}_{2}\right) 138.4(\mathrm{pz}), 135.0\left(\mathrm{~d}, J_{\mathrm{C}, \mathrm{P}}=48 \mathrm{~Hz}, \mathrm{C}^{i} \mathrm{PPh}_{2}\right), 134.8(\mathrm{pz}), 133.5\left(\mathrm{~d}, J_{\mathrm{C}, \mathrm{P}}=11 \mathrm{~Hz}\right)$ and $131.5\left(\mathrm{~d}, J_{\mathrm{C}, \mathrm{P}}=11 \mathrm{~Hz}\right)\left(\mathrm{C}^{o} \mathrm{PPh}_{2}\right), 129.6\left(\mathrm{~d}, J_{\mathrm{C}, \mathrm{P}}=2 \mathrm{~Hz}\right)$ and $129.2\left(\mathrm{~d}, J_{\mathrm{C}, \mathrm{P}}=2 \mathrm{~Hz}\right)\left(\mathrm{C}^{p} \mathrm{PPh}_{2}\right)$, $128.3\left(\mathrm{~d}, J_{\mathrm{C}, \mathrm{P}}=10 \mathrm{~Hz}\right)$ and $128.1\left(\mathrm{~d}, J_{\mathrm{C}, \mathrm{P}}=10 \mathrm{~Hz}\right)\left(\mathrm{C}^{m} \mathrm{PPh}_{2}\right), 126.7\left(\mathrm{dd}, J_{\mathrm{C}, \mathrm{Rh}}=18 \mathrm{~Hz}, J_{\mathrm{C}, \mathrm{P}}=7\right.$ $\mathrm{Hz},=\mathrm{CH}-\eta^{2}$-allyl), $111.4\left(=\mathrm{CH}_{2}\right.$-allyl), $105.2(\mathrm{pz}), 79.8\left(\mathrm{dd}, J_{\mathrm{C}, \mathrm{Rh}}=12 \mathrm{~Hz}, J_{\mathrm{C}, \mathrm{P}}=6 \mathrm{~Hz},=\mathrm{CH}_{2}-\eta^{2}-\right.$ allyl), 45.7 (br s, $\mathrm{CH}_{2}-\eta^{2}$-allyl), $31.7\left(\mathrm{CH}_{2}\right.$-allyl), 21.5 (br, $\left.\mathrm{CH}_{2} \mathrm{P}\right) . \operatorname{MALDI}(+): m / z 840\left(\mathrm{M}^{+}-\right.$ allyl-CO).

$\left[\mathbf{R h}\left(\kappa^{2}-\mathbf{A}_{2} \mathbf{B P N}\right)(\mathbf{C O}) \mathbf{p y}\right](\mathbf{9})$. To a yellow solution of $\mathbf{8}(0.12 \mathrm{~g}, 0.13 \mathrm{mmol})$ in dietyl ether $(6$ $\mathrm{mL}$ ), pyridine ( $21 \mathrm{mg}, 21 \mu \mathrm{L}, 0.26 \mathrm{mmol}$ ) was added via syringe. After 1 hour of stirring a brown solid was formed, which was filtered out, washed with cold hexanes and vacuum-dried. Yield: $0.13 \mathrm{~g}(88 \%)$. Anal. Calcd (\%) for $\mathrm{C}_{28} \mathrm{H}_{30} \mathrm{BN}_{3} \mathrm{OPRh}$ (569.25): C 59.08, H 5.31, N 7.38; found: C 59.13, H 5.28, N 7.25. IR (ATR): $v(\mathrm{CO}) / \mathrm{cm}^{-1}: 1967$ (s); IR (toluene): $v(\mathrm{CO}) / \mathrm{cm}^{-1}$ : 1977 (s). ${ }^{1} \mathrm{H}$ NMR (300 MHz, $\mathrm{C}_{6} \mathrm{D}_{6}, 25^{\circ} \mathrm{C}$ ): $\delta 8.36$ (s, 1H, py), 7.91 (m, 4H, $\mathrm{H}^{o} \mathrm{PPh}_{2}$ ), 7.76 (d, $J$ $=3.0 \mathrm{~Hz}, 1 \mathrm{H}, \mathrm{pz}), 7.27$ (s, 1H, py), $7.14\left(\mathrm{~m}, 6 \mathrm{H}, \mathrm{H}^{m+p} \mathrm{PPh}_{2}+1 \mathrm{H}, \mathrm{py}\right), 6.71(\mathrm{~d}, J=3.0 \mathrm{~Hz}, 1 \mathrm{H}$, pz), 6.38 (m, 2H, =CH-allyl), 6.35 (s, 1H, py), 6.32 (s, 1H, py), 5.87 (t, J=3.0 Hz, 1H, pz), 5.36 $(\mathrm{d}, J=17.1 \mathrm{~Hz}, 2 \mathrm{H})$ and $5.25(\mathrm{~d}, J=9.9 \mathrm{~Hz}, 2 \mathrm{H})\left(=\mathrm{CH}_{2}\right.$-allyl), $2.85(\mathrm{~m}, 2 \mathrm{H})$ and $2.36(\mathrm{~m}, 2 \mathrm{H})$ $\left(\mathrm{CH}_{2}\right.$-allyl), 1.95 (d, $\left.J_{\mathrm{H}, \mathrm{P}}=15.0 \mathrm{~Hz}, 2 \mathrm{H}, \mathrm{CH}_{2} \mathrm{P}\right) .{ }^{31} \mathrm{P}\left\{{ }^{1} \mathrm{H}\right\} \mathrm{NMR}\left(121 \mathrm{MHz}, \mathrm{C}_{6} \mathrm{D}_{6}, 25{ }^{\circ} \mathrm{C}\right): \delta 41.7$ $\left(\mathrm{d}, J_{\mathrm{P}, \mathrm{Rh}}=145 \mathrm{~Hz}\right) \cdot{ }^{13} \mathrm{C}\left\{{ }^{1} \mathrm{H}\right\} \operatorname{NMR}\left(100 \mathrm{MHz}, \mathrm{C}_{6} \mathrm{D}_{6}, 25{ }^{\circ} \mathrm{C}\right): \delta 191.0\left(\mathrm{dd}, J_{\mathrm{C}, \mathrm{Rh}}=56 \mathrm{~Hz}, J_{\mathrm{C}, \mathrm{P}}=13\right.$ Hz, CO), 151.4 (py), 142.3 (=CH-allyl), 138.0 (pz), 137.4 (d, $J_{\mathrm{C}, \mathrm{P}}=36 \mathrm{~Hz}, \mathrm{C}^{i} \mathrm{PPh}_{2}$ ), 135.9 (py), 133.6 (pz), $131.7\left(\mathrm{~d}, J_{\mathrm{C}, \mathrm{P}}=10 \mathrm{~Hz}, \mathrm{C}^{o} \mathrm{PPh}_{2}\right), 128.1(\mathrm{py}), 126.2-128.5\left(\mathrm{C}^{m+p} \mathrm{PPh}_{2}+\mathrm{py}\right), 123.4$

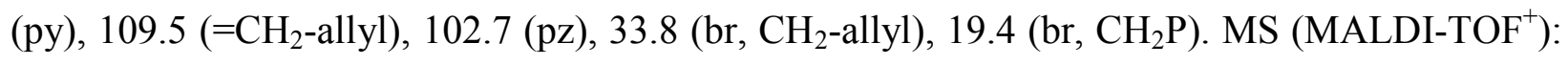
$m / z$ (\%): 529.3 (90) [M-allyl] $]^{+}, 491.3(70)[\mathrm{M}-\text { py }]^{+}$. 
$\left[\mathbf{R h}\left(\boldsymbol{\kappa}^{2}-\mathbf{A}_{2} \mathbf{B P N}\right)(\mathbf{C O}) \mathbf{N H}_{3}\right] \mathbf{( 1 0 )}$. A solution of $\mathbf{8}(0.02 \mathrm{~g}, 0.02 \mathrm{mmol})$ in $\mathrm{C}_{6} \mathrm{D}_{6}(0.5 \mathrm{~mL})$ was shaken with gaseous ammonia leading to a colourless solution within five minutes. Inspection of the NMR spectra revealed a clean and quantitative conversion to complex 10. IR $\left(\mathrm{C}_{6} \mathrm{D}_{6}\right)$ : $v(\mathrm{CO}) / \mathrm{cm}^{-1}: 1972(\mathrm{~s}) .{ }^{1} \mathrm{H}$ NMR $\left(300 \mathrm{MHz}, \mathrm{C}_{6} \mathrm{D}_{6}, 25^{\circ} \mathrm{C}\right): \delta 7.81\left(\mathrm{~m}, 4 \mathrm{H}, \mathrm{H}^{o} \mathrm{PPh}_{2}\right), 7.71(\mathrm{~s}, 1 \mathrm{H}$, pz), $7.12\left(\mathrm{~m}, 6 \mathrm{H}, \mathrm{H}^{m+p} \mathrm{PPh}_{2}\right), 6.81(\mathrm{~s}, 1 \mathrm{H}, \mathrm{pz}), 6.31(\mathrm{~m}, 2 \mathrm{H},=\mathrm{CH}-\mathrm{allyl}), 5.96(\mathrm{~s}, 1 \mathrm{H}, \mathrm{pz}), 5.22(\mathrm{~d}$, $J=15.6 \mathrm{~Hz}, 2 \mathrm{H})$ and $5.14(\mathrm{~d}, J=10.2 \mathrm{~Hz}, 2 \mathrm{H})\left(=\mathrm{CH}_{2}\right.$-allyl $), 2.73(\mathrm{~m}, 2 \mathrm{H})$ and $2.25(\mathrm{~m}, 2 \mathrm{H})$ $\left(\mathrm{CH}_{2}\right.$-allyl), $1.83\left(\mathrm{~d}, J_{\mathrm{H}, \mathrm{P}}=15.0 \mathrm{~Hz}, 2 \mathrm{H}, \mathrm{CH}_{2} \mathrm{P}\right),-0.03$ (free and coordinated $\left.\mathrm{NH}_{3}\right) .{ }^{31} \mathrm{P}\left\{{ }^{1} \mathrm{H}\right\}$ NMR $\left(121 \mathrm{MHz}, \mathrm{C}_{6} \mathrm{D}_{6}, 25{ }^{\circ} \mathrm{C}\right): \delta 42.0\left(\mathrm{~d}, J_{\mathrm{P}, \mathrm{Rh}}=150 \mathrm{~Hz}\right) .{ }^{13} \mathrm{C}\left\{{ }^{1} \mathrm{H}\right\}$ NMR $\left(75 \mathrm{MHz}, \mathrm{C}_{6} \mathrm{D}_{6}, 25\right.$ $\left.{ }^{\circ} \mathrm{C}\right): \delta 192.3\left(\mathrm{dd}, J_{\mathrm{C}, \mathrm{Rh}}=74 \mathrm{~Hz}, J_{\mathrm{C}, \mathrm{P}}=17 \mathrm{~Hz}, \mathrm{CO}\right), 143.6(=\mathrm{CH}-\mathrm{allyl}), 138.7\left(\mathrm{~d}, J_{\mathrm{C}, \mathrm{P}}=47 \mathrm{~Hz}, \mathrm{C}^{i}\right.$ $\left.\mathrm{PPh}_{2}\right), 137.9$ and $134.6(\mathrm{pz}), 132.7\left(\mathrm{~d}, J_{\mathrm{C}, \mathrm{P}}=11 \mathrm{~Hz}, \mathrm{C}^{o} \mathrm{PPh}_{2}\right), 129.1\left(\mathrm{~d}, J_{\mathrm{C}, \mathrm{P}}=2 \mathrm{~Hz}, \mathrm{C}^{p} \mathrm{PPh}_{2}\right)$, $127.9\left(\mathrm{~d}, J_{\mathrm{C}, \mathrm{P}}=10 \mathrm{~Hz}, \mathrm{C}^{m} \mathrm{PPh}_{2}\right), 110.1$ (= $\mathrm{CH}_{2}$-allyl), 104.1 (pz), 34.9 (br, $\mathrm{CH}_{2}$-allyl), 20.7 (br, $\left.\mathrm{CH}_{2} \mathrm{P}\right)$. MS (MALDI-TOF $\left.{ }^{+}\right): m / z(\%): 478.1(80)\left[\mathrm{M}^{-} \mathrm{CO}\right]^{+}$.

$\left[\mathbf{R h}\left(\boldsymbol{\kappa}^{2}-\mathbf{A}_{2} \mathbf{B P N}\right)(\mathbf{C O}) \mathbf{P P h}_{3}\right] \mathbf{( 1 1 )}$. To a solution of $\mathbf{8}(0.15 \mathrm{~g}, 0.17 \mathrm{mmol})$ in diethyl ether $(7$ $\mathrm{mL})$, solid triphenylphosphane $(0.089 \mathrm{~g}, 0.34 \mathrm{mmol})$ was added and the resulting yellow mixture was stirred for $30 \mathrm{~min}$. Evaporation of the solvent under vacuum to ca. $2 \mathrm{ml}$ and slow addition of hexanes $(7 \mathrm{ml})$ caused the precipitation of an orange solid, which was filtered, washed with cold hexanes and then vacuum-dried. Yield: $0.13 \mathrm{~g}(88 \%)$. Anal. Calcd (\%) for $\mathrm{C}_{41} \mathrm{H}_{40} \mathrm{BN}_{2} \mathrm{OP}_{2} \mathrm{Rh}$ (752.44): C 65.45, H 5.36, N 3.72; found: C 65.15, H 5.15, N 3.92. IR (ATR): $v(C O) / \mathrm{cm}^{-1}: 1976$ (s), IR (toluene): $v(\mathrm{CO}) / \mathrm{cm}^{-1}: 1981$ (s). ${ }^{1} \mathrm{H}$ NMR $\left(300 \mathrm{MHz}, \mathrm{C}_{6} \mathrm{D}_{6}, 25{ }^{\circ} \mathrm{C}\right): \delta 7.24\left(\mathrm{~m}, 10 \mathrm{H}, \mathrm{H}^{o}\right.$ $\mathrm{PPh}_{2}+\mathrm{PPh}_{3}$ ), $6.87(\mathrm{~s}, 1 \mathrm{H}, \mathrm{pz}), 6.69\left(\mathrm{~m}, 15 \mathrm{H}, \mathrm{H}^{m+p} \mathrm{PPh}_{2}+\mathrm{PPh}_{3}\right), 6.29$ (d, $\left.J=3.0 \mathrm{~Hz}, 1 \mathrm{H}, \mathrm{pz}\right)$ $6.08(\mathrm{~m}, 2 \mathrm{H},=\mathrm{CH}-\mathrm{allyl}), 5.17(\mathrm{t}, J=2.2 \mathrm{~Hz}, 1 \mathrm{H}, \mathrm{pz}), 5.02(\mathrm{dd}, J=17.0,3.0 \mathrm{~Hz}, 2 \mathrm{H})$ and 4.86 $(\mathrm{dd}, J=10.0,3.0 \mathrm{~Hz}, 2 \mathrm{H})\left(=\mathrm{CH}_{2}\right.$-allyl), $2.13\left(\mathrm{~m}, 4 \mathrm{H}, \mathrm{CH}_{2}\right.$-allyl), $1.58\left(\mathrm{~d}, J_{\mathrm{H}, \mathrm{P}}=11.7 \mathrm{~Hz}, 2 \mathrm{H}\right.$, $\left.\mathrm{CH}_{2} \mathrm{P}\right) .{ }^{31} \mathrm{P}\left\{{ }^{1} \mathrm{H}\right\} \mathrm{NMR}\left(121 \mathrm{MHz}, \mathrm{C}_{6} \mathrm{D}_{6}, 25^{\circ} \mathrm{C}\right): \mathrm{ABX}$ spin system $\left(\mathrm{X}={ }^{103} \mathrm{Rh}\right) \delta_{\mathrm{P}}^{\mathrm{A}}=31.6, \delta_{\mathrm{P}}^{\mathrm{B}}=$ 
$\left.30.0, J_{\mathrm{P}^{\mathrm{A}}}, \mathrm{P}^{\mathrm{B}}=297 \mathrm{~Hz}, J_{\mathrm{P}^{\mathrm{A}}, \mathrm{Rh}}=122 \mathrm{~Hz}, J_{\mathrm{P}^{\mathrm{B}}}{ }^{\mathrm{R} h}=125 \mathrm{~Hz}\right) \cdot{ }^{13} \mathrm{C}\left\{{ }^{1} \mathrm{H}\right\}\left(75 \mathrm{MHz}, \mathrm{C}_{6} \mathrm{D}_{6}, 25^{\circ} \mathrm{C}\right): \delta 192.9$ $\left(\mathrm{ddd}, J_{\mathrm{C}, \mathrm{Rh}}=71 \mathrm{~Hz}, J_{\mathrm{P}, \mathrm{C}}=16,12 \mathrm{~Hz}, \mathrm{CO}\right), 143.6\left(=\mathrm{CH}-\right.$ allyl), $140.9(\mathrm{pz}), 137.2\left(\mathrm{dd}, J_{\mathrm{C}, \mathrm{P}}=40,12\right.$ $\left.\mathrm{Hz}, \mathrm{C}^{i} \mathrm{PPh}_{3}\right), 135.2(\mathrm{pz}), 134.4\left(\mathrm{~d}, J_{\mathrm{C}, \mathrm{P}}=11 \mathrm{~Hz}, \mathrm{C}^{o} \mathrm{PPh}_{2}\right), 133.9$ (dd, $\left.J_{\mathrm{C}, \mathrm{P}}=39,9 \mathrm{~Hz}, \mathrm{C}^{i} \mathrm{PPh}_{3}\right)$, $132.6\left(\mathrm{dd}, J_{\mathrm{C}, \mathrm{P}}=10 \mathrm{~Hz}, \mathrm{C}^{o} \mathrm{PPh}_{2}\right), 130.3\left(\mathrm{C}^{p} \mathrm{PPh}_{3}\right), 129.2\left(\mathrm{C}^{p} \mathrm{PPh}_{2}\right), 128.5\left(\mathrm{~d}, J_{\mathrm{C}, \mathrm{P}}=8 \mathrm{~Hz}, \mathrm{C}^{m}\right.$ $\left.\mathrm{PPh}_{3}\right), 127.9\left(\mathrm{~d}, J_{\mathrm{C}, \mathrm{P}}=8 \mathrm{~Hz}, \mathrm{C}^{m} \mathrm{PPh}_{2}\right), 110.8$ (= $\mathrm{CH}_{2}$-allyl), 104.1 (pz), 35.5 (br, $\mathrm{CH}_{2}$-allyl), 19.4 (br, $\left.\mathrm{CH}_{2} \mathrm{P}\right)$. MS (MALDI-TOF ${ }^{+}$): $m / z(\%): 711.0(30)[\mathrm{M}-\mathrm{allyl}]^{+}$.

[Rh $\left.\left(\boldsymbol{\kappa}^{2}-\mathbf{A}_{2} \mathbf{B P N}\right)(\mathbf{C O}) \mathbf{P M e}_{3}\right]$ (12). A solution of $\mathbf{8}(0.10 \mathrm{~g}, 0.11 \mathrm{mmol})$ in toluene $(10 \mathrm{~mL})$ was treated with trimethylphosphane ( $16 \mathrm{mg}, 23 \mu \mathrm{L}, 0.22 \mathrm{mmol})$ via syringe and the resulting yellow mixture was stirred for $15 \mathrm{~min}$. Evaporation of the solvent under vacuum to ca. $5 \mathrm{~mL}$ and slow addition of hexanes $(10 \mathrm{~mL})$ caused the precipitation of a yellow solid, which was filtered, washed with cold hexanes and then vacuum-dried. Yield: $0.10 \mathrm{~g} \mathrm{(95 \% ).} \mathrm{Anal.} \mathrm{Calcd} \mathrm{( \% )} \mathrm{for}$ $\mathrm{C}_{26} \mathrm{H}_{34} \mathrm{BN}_{2} \mathrm{OP}_{2} \mathrm{Rh}$ (566.23): C 55.15, H 6.05, N 4.95; found: C 55.05, H 6.10, N 4.92. IR (ATR): $v(\mathrm{CO}) / \mathrm{cm}^{-1}: 1970$ (s), IR (toluene): $v(\mathrm{CO}) / \mathrm{cm}^{-1}: 1977$ (s). ${ }^{1} \mathrm{H}$ NMR $\left(300 \mathrm{MHz}, \mathrm{C}_{6} \mathrm{D}_{6}, 25^{\circ} \mathrm{C}\right): \delta$ $7.71\left(\mathrm{~m}, 4 \mathrm{H}, \mathrm{H}^{o} \mathrm{PPh}_{2}+1 \mathrm{H}, \mathrm{pz}\right), 7.10\left(\mathrm{~m}, 6 \mathrm{H}, \mathrm{H}^{m+p} \mathrm{PPh}_{2}+1 \mathrm{H}, \mathrm{pz}\right), 6.32(\mathrm{~m}, 2 \mathrm{H},=\mathrm{CH}-$ allyl) $5.93(\mathrm{t}, J=2.1 \mathrm{~Hz}, 1 \mathrm{H}, \mathrm{pz}), 5.39(\mathrm{dd}, J=17.1,3.0 \mathrm{~Hz}, 2 \mathrm{H})$ and $5.24(\mathrm{dd}, J=9.9,3.0 \mathrm{~Hz}, 2 \mathrm{H})$ (=CH $\mathrm{CH}_{2}$-allyl), $2.62\left(\mathrm{~m}, 2 \mathrm{H}\right.$, ) and $2.30(\mathrm{~m}, 2 \mathrm{H})\left(\mathrm{CH}_{2}\right.$-allyl), $1.85\left(\mathrm{~d}, J_{\mathrm{H}, \mathrm{P}}=13.2 \mathrm{~Hz}, 2 \mathrm{H}, \mathrm{CH}_{2} \mathrm{P}\right)$, $1.00\left(\mathrm{~d}, J_{\mathrm{H}, \mathrm{P}}=10.5 \mathrm{~Hz}, 9 \mathrm{H}, \mathrm{PMe}_{3}\right) .{ }^{31} \mathrm{P}\left\{{ }^{1} \mathrm{H}\right\} \mathrm{NMR}\left(121 \mathrm{MHz}, \mathrm{C}_{6} \mathrm{D}_{6}, 25{ }^{\circ} \mathrm{C}\right): \delta 28.8\left(\mathrm{dd}, J_{\mathrm{P}, \mathrm{P}}=\right.$ $\left.309 \mathrm{~Hz}, J_{\mathrm{P}, \mathrm{Rh}}=116 \mathrm{~Hz}\right),-12.6\left(\mathrm{dd}, J_{\mathrm{P}, \mathrm{P}}=309 \mathrm{~Hz}, J_{\mathrm{P}, \mathrm{Rh}}=121 \mathrm{~Hz}\right) \cdot{ }^{13} \mathrm{C}\left\{{ }^{1} \mathrm{H}\right\} \mathrm{NMR}(75 \mathrm{MHz}$, $\mathrm{C}_{6} \mathrm{D}_{6}, 25^{\circ} \mathrm{C}$ ): $\delta 193.1$ (ddd, $J_{\mathrm{C}, \mathrm{Rh}}=69 \mathrm{~Hz}, J_{\mathrm{C}, \mathrm{P}}=15,12 \mathrm{~Hz}, \mathrm{CO}$ ), 143.5 (=CH-allyl), $140.0(\mathrm{pz})$, $137.1\left(\mathrm{~d}, J_{\mathrm{C}, \mathrm{P}}=41 \mathrm{~Hz}, \mathrm{C}^{i} \mathrm{PPh}_{2}\right), 134.7(\mathrm{pz}), 132.4\left(\mathrm{~d}, J_{\mathrm{C}, \mathrm{P}}=11 \mathrm{~Hz}, \mathrm{C}^{o} \mathrm{PPh}_{2}\right), 129.1\left(\mathrm{C}^{p} \mathrm{PPh}_{2}\right)$, $127.9\left(\mathrm{~d}, J_{\mathrm{C}, \mathrm{P}}=9 \mathrm{~Hz}, \mathrm{C}^{m} \mathrm{PPh}_{2}\right), 110.1$ (= $\mathrm{CH}_{2}$-allyl), 104.1 (pz), 34.6 (br, $\mathrm{CH}_{2}$-allyl), 19.8 (br, $\left.\mathrm{CH}_{2} \mathrm{P}\right), 17.0\left(\mathrm{~d}, J_{\mathrm{C}, \mathrm{P}}=26 \mathrm{~Hz}, \mathrm{PMe}_{3}\right) . \mathrm{MS}\left(\mathrm{MALDI}-\mathrm{TOF}^{+}\right): \mathrm{m} / z(\%): 525.2(85)[\mathrm{M}-\mathrm{allyl}]^{+}, 539.2$ (20) $[\mathrm{M}-\mathrm{CO}]^{+}$. 
$\left[\operatorname{Ir}\left(\mathrm{K}^{3}-\mathbf{A}_{2} \mathbf{B P N}\right)(\mathbf{C O}) \mathbf{P P h}_{3}\right]$ (13). A suspension of $\mathbf{3}(0.44 \mathrm{~g}, 0.66 \mathrm{mmol})$ in diethyl ether (20 $\mathrm{mL}$ ) was bubbled with carbon monoxide to give a bright yellow solution in $30 \mathrm{~min}$. The addition of triphenylphosphane $(0.17 \mathrm{~g}, 0.66 \mathrm{mmol})$ to this solution caused the discharge of the color within seconds. After 20 minutes, evaporation of the solvent under vacuum gave an orange oil, that was washed with cold hexanes to yield a pale yellow solid, which was filtered and then vacuum-dried. Yield: $0.49 \mathrm{~g}(88 \%)$. Anal. Calcd (\%) for $\mathrm{C}_{41} \mathrm{H}_{40} \mathrm{BIrN}_{2} \mathrm{OP}_{2}$ (841.76): C 58.50, $\mathrm{H}$ 4.79, N 3.33; found: C 58.74, H 4.93, N 3.29. IR (ATR): $v(\mathrm{CO}) / \mathrm{cm}^{-1}: 2008$ (s), IR (toluene): $v(\mathrm{CO}) / \mathrm{cm}^{-1}: 2000(\mathrm{~m}), 1978(\mathrm{~s}) .{ }^{1} \mathrm{H}$ NMR $\left(300 \mathrm{MHz}, \mathrm{d}_{8}\right.$-toluene, $\left.25{ }^{\circ} \mathrm{C}\right): \delta 7.61\left(\mathrm{~m}, 10 \mathrm{H}, \mathrm{H}^{o}\right.$ $\left.\mathrm{PPh}_{2}+\mathrm{PPh}_{3}\right), 7.54(\mathrm{~d}, J=2.0 \mathrm{~Hz}, 1 \mathrm{H}, \mathrm{pz}), 7.06\left(\mathrm{~m}, 15 \mathrm{H}, \mathrm{H}^{m+p} \mathrm{PPh}_{2}+\mathrm{PPh}_{3}\right), 6.77$ (d, J=1.8 Hz, 1H, pz), $5.92(\mathrm{~m}, 2 \mathrm{H},=\mathrm{CH}$-allyl), $5.53(\mathrm{~d}, J=2.1 \mathrm{~Hz}, 1 \mathrm{H}, \mathrm{pz}), 4.82(\mathrm{~d}, J=9.9 \mathrm{~Hz}, 2 \mathrm{H})$ and 4.67 $(\mathrm{d}, J=15.9 \mathrm{~Hz}, 2 \mathrm{H})\left(=\mathrm{CH}_{2}\right.$-allyl $), 2.31(\mathrm{~m}, 2 \mathrm{H})$ and $2.05(\mathrm{~m}, 2 \mathrm{H})\left(\mathrm{CH}_{2}\right.$-allyl $), 2.02\left(\mathrm{~d},{ }^{2} J_{\mathrm{H}, \mathrm{P}}=\right.$ $\left.12.0 \mathrm{~Hz}, 2 \mathrm{H}, \mathrm{CH}_{2} \mathrm{P}\right) .{ }^{31} \mathrm{P}\left\{{ }^{1} \mathrm{H}\right\}$ NMR $\left(121 \mathrm{MHz}, \mathrm{d}_{8}\right.$-toluene, $\left.25{ }^{\circ} \mathrm{C}\right): \mathrm{AB}$ spin system $\delta_{\mathrm{P}}{ }^{\mathrm{A}}=17.7$,

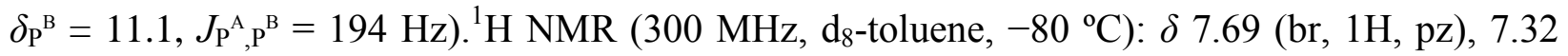
(m, 4H, $\mathrm{H}^{o} \mathrm{PPh}_{2}$ ), $6.93\left(\mathrm{~m}, 6 \mathrm{H}, \mathrm{H}^{m+p} \mathrm{PPh}_{2}+15 \mathrm{H}, \mathrm{PPh}_{3}\right.$ ), 6.78 (m, 1H, =CH-allyl), 6.69 (br, 1H, pz), $5.56(\mathrm{~d}, J=15.9 \mathrm{~Hz}, 1 \mathrm{H})$ and $5.50(\mathrm{~d}, J=12.5 \mathrm{~Hz}, 1 \mathrm{H})\left(=\mathrm{CH}_{2}\right.$-allyl $), 5.52(\mathrm{~s}, 1 \mathrm{H}, \mathrm{pz}), 3.79$ (br, $1 \mathrm{H},=\mathrm{CH}-\eta^{2}$-allyl), $3.28\left(\mathrm{br}, 1 \mathrm{H},=\mathrm{CH}_{2}-\eta^{2}\right.$-allyl), $2.32(\mathrm{br}, 1 \mathrm{H})$ and $2.22(\mathrm{br}, 1 \mathrm{H})\left(\mathrm{CH}_{2}\right.$-allyl), $2.14\left(\mathrm{br}, 1 \mathrm{H},=\mathrm{CH}-\eta^{2}\right.$-allyl), 0,98 (m, 1H, $\mathrm{CH}_{2}-\eta^{2}$-allyl $\left.+2 \mathrm{H}, \mathrm{CH}_{2} \mathrm{P}\right), 0.78\left(\mathrm{br}, 1 \mathrm{H}, \mathrm{CH}_{2}-\eta^{2}\right.$-allyl).

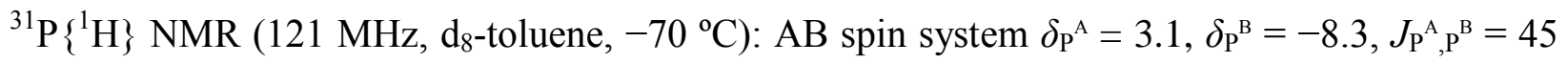
Hz). ${ }^{13} \mathrm{C}\left\{{ }^{1} \mathrm{H}\right\} \operatorname{NMR}\left(75 \mathrm{MHz}, \mathrm{CDCl}_{3}, 25^{\circ} \mathrm{C}\right) \delta 175.7\left(\mathrm{t}, J_{\mathrm{C}, \mathrm{P}}=10 \mathrm{~Hz}, \mathrm{CO}\right), 142.5(\mathrm{pz}), 142.4(\mathrm{~d}$, $J_{\mathrm{C}, \mathrm{P}}=7 \mathrm{~Hz},=\mathrm{CH}$-allyl $), 138.0\left(\mathrm{~d}, J_{\mathrm{C}, \mathrm{P}}=41 \mathrm{~Hz}, \mathrm{C}^{i} \mathrm{PPh}_{3}\right), 134.3(\mathrm{pz}), 134.2\left(\mathrm{~d}, J_{\mathrm{C}, \mathrm{P}}=12 \mathrm{~Hz}, \mathrm{C}^{o}\right.$ $\left.\mathrm{PPh}_{3}\right), 133.7\left(\mathrm{dd}, J_{\mathrm{C}, \mathrm{P}}=43 \mathrm{~Hz}, \mathrm{C}^{i} \mathrm{PPh}_{2}\right), 132.2\left(\mathrm{~d}, J_{\mathrm{C}, \mathrm{P}}=11 \mathrm{~Hz}, \mathrm{C}^{o} \mathrm{PPh}_{2}\right), 130.0\left(\mathrm{~d}, J_{\mathrm{C}, \mathrm{P}}=2 \mathrm{~Hz}\right.$, $\left.\mathrm{C}^{p} \mathrm{PPh}_{3}\right), 128.9\left(\mathrm{~d}, J_{\mathrm{C}, \mathrm{P}}=2 \mathrm{~Hz}, \mathrm{C}^{p} \mathrm{PPh}_{2}\right), 128.2\left(\mathrm{~d}, J_{\mathrm{C}, \mathrm{P}}=10 \mathrm{~Hz}, \mathrm{C}^{m} \mathrm{PPh}_{3}\right), 127.7\left(\mathrm{~d}, J_{\mathrm{C}, \mathrm{P}}=10\right.$ 
$\left.\mathrm{Hz}, \mathrm{C}^{m} \mathrm{PPh}_{2}\right), 115.0\left(=\mathrm{CH}_{2}\right.$-allyl), 104.2 (pz), 29.7 (br, $\mathrm{CH}_{2}$-allyl), 28.0 (br, $\left.\mathrm{CH}_{2} \mathrm{P}\right) . \mathrm{MS}$ (MALDI-TOF ${ }^{+}$): $m / z$ (\%): $801.1(100)$ [M-allyl] ${ }^{+}$

[Ir( $\left.\left.\boldsymbol{K}^{3}-\mathbf{A}_{2} \mathbf{B P N}\right)(\mathbf{C O}) \mathbf{P M e}_{3}\right]$ (14). A solution of $7(0.33 \mathrm{~g}, 0.50 \mathrm{mmol})$ in diethyl ether $(20 \mathrm{~mL})$ was bubbled with carbon monoxide giving in $30 \mathrm{~min}$ a bright yellow solution. The addition of trimethylphosphane ( $37 \mathrm{mg}, 51 \mu \mathrm{L}, 0.50 \mathrm{mmol}$ ) to this solution caused the discharge of the color to form a white solution within $1 \mathrm{~min}$ and then a white solid began to crystallize out after $5 \mathrm{~min}$ of stirring. The solid was collected by filtration, washed with cold hexanes and then vacuumdried. Yield: $0.27 \mathrm{~g}(98 \%)$. Anal. Calcd (\%) for $\mathrm{C}_{26} \mathrm{H}_{34} \mathrm{BIrN}_{2} \mathrm{OP}_{2}$ (655.55): C 47.64, H 5.23, N 4.27; found: $\mathrm{C} 47.35, \mathrm{H} 5.19, \mathrm{~N}$ 4.11. IR (ATR): $v(\mathrm{CO}) / \mathrm{cm}^{-1}: 1920$ (s), IR (toluene): $v(\mathrm{CO}) / \mathrm{cm}^{-1}: 1928(\mathrm{~s}) .{ }^{1} \mathrm{H}$ NMR $\left(300 \mathrm{MHz}, \mathrm{C}_{6} \mathrm{D}_{6}, 25^{\circ} \mathrm{C}\right): \delta 7.96(\mathrm{~d}, J=2.0 \mathrm{~Hz}, 1 \mathrm{H}, \mathrm{pz}), 7.93(\mathrm{~m}$, $2 \mathrm{H})$ and $7.45(\mathrm{~m}, 2 \mathrm{H})\left(\mathrm{H}^{o+o} \mathrm{PPh}_{2}\right), 7.43(\mathrm{~d}, J=2.1 \mathrm{~Hz}, 1 \mathrm{H}, \mathrm{pz}), 7.23\left(\mathrm{td}, J=6.7,1.1 \mathrm{~Hz}, 2 \mathrm{H}, \mathrm{H}^{m}\right.$ $\left.\mathrm{PPh}_{2}\right), 7.05\left(\mathrm{td}, J=7.0,1.1 \mathrm{~Hz}, 1 \mathrm{H}, \mathrm{H}^{p} \mathrm{PPh}_{2}\right), 7.00\left(\mathrm{~m}, 3 \mathrm{H}, \mathrm{H}^{m^{4}+p^{c}} \mathrm{PPh}_{2}\right), 6.63(\mathrm{~m}, 1 \mathrm{H},=\mathrm{CH}-$ allyl), $5.89(\mathrm{t}, J=2.1 \mathrm{~Hz}, 1 \mathrm{H}, \mathrm{pz}), 5.36(\mathrm{dd}, J=16.8,3.0 \mathrm{~Hz}, 1 \mathrm{H})$ and $5.28(\mathrm{dd}, J=10.2,3.0 \mathrm{~Hz}$, 1H) $\left(=\mathrm{CH}_{2}\right.$-allyl), $2.93\left(\mathrm{~m}, 1 \mathrm{H},=\mathrm{CH}-\eta^{2}\right.$-allyl $), 2.82(\mathrm{~m}, 1 \mathrm{H})$ and $2.47(\mathrm{~m}, 1 \mathrm{H})\left(=\mathrm{CH}_{2}-\eta^{2}\right.$-allyl $)$, $2.17\left(\mathrm{~m}, 1 \mathrm{H}, \mathrm{CH}_{2}-\eta^{2}\right.$-allyl), $2.04\left(\mathrm{~m}, 2 \mathrm{H}, \mathrm{CH}_{2}\right.$-allyl $\left.+1 \mathrm{H}, \mathrm{CH}_{2} \mathrm{P}\right), 1.34\left(\mathrm{t}, J_{\mathrm{H}, \mathrm{H}}=J_{\mathrm{H}, \mathrm{P}}=13.6 \mathrm{~Hz}\right.$, $\left.1 \mathrm{H}, \mathrm{CH}_{2} \mathrm{P}\right), 1.10\left(\mathrm{~m}, 1 \mathrm{H}, \mathrm{CH}_{2}-\eta^{2}\right.$-allyl $), 0.58\left(\mathrm{~d}, J_{\mathrm{H}, \mathrm{P}}=10.5 \mathrm{~Hz}, 9 \mathrm{H}, \mathrm{PMe}_{3}\right) .{ }^{31} \mathrm{P}\left\{{ }^{1} \mathrm{H}\right\}$ NMR $(121$ $\left.\mathrm{MHz}, \mathrm{C}_{6} \mathrm{D}_{6}, 25{ }^{\circ} \mathrm{C}\right): \delta 3.3\left(\mathrm{~d}, J_{\mathrm{P}, \mathrm{P}}=12 \mathrm{~Hz}\right),-42.2\left(\mathrm{~d}, J_{\mathrm{P}, \mathrm{P}}=12 \mathrm{~Hz}\right) \cdot{ }^{13} \mathrm{C}\left\{{ }^{1} \mathrm{H}\right\} \mathrm{NMR}(75 \mathrm{MHz}$, $\left.\mathrm{C}_{6} \mathrm{D}_{6}, 25^{\circ} \mathrm{C}\right) \delta 190.7\left(\mathrm{dd}, J_{\mathrm{C}, \mathrm{P}}=17 \mathrm{~Hz}, 14 \mathrm{~Hz}, \mathrm{CO}\right), 143.7$ (=CH-allyl), $143.3(\mathrm{pz}), 138.2\left(\mathrm{~d}, J_{\mathrm{C}, \mathrm{P}}\right.$ $\left.=36 \mathrm{~Hz}, \mathrm{C}^{i} \mathrm{PPh}_{2}\right), 133.9\left(\mathrm{~d}, J_{\mathrm{C}, \mathrm{P}}=13 \mathrm{~Hz}, \mathrm{C}^{o} \mathrm{PPh}_{2}\right), 131.3(\mathrm{pz}), 131.1\left(\mathrm{~d}, J_{\mathrm{C}, \mathrm{P}}=5 \mathrm{~Hz}, \mathrm{C}^{p} \mathrm{PPh}_{2}\right)$, $128.0\left(\mathrm{~m}, \mathrm{C}^{m} \mathrm{PPh}_{2}\right), 110.5$ (=CH -allyl), $105.5(\mathrm{pz}), 49.8\left(\mathrm{~d}, J_{\mathrm{C}, \mathrm{P}}=8 \mathrm{~Hz},=\mathrm{CH}-\eta^{2}\right.$-allyl), $35.5(\mathrm{~d}$, $J_{\mathrm{C}, \mathrm{P}}=20 \mathrm{~Hz},=\mathrm{CH}_{2}-\eta^{2}$-allyl), $34.4\left(\mathrm{br}, \mathrm{CH}_{2}\right.$-allyl), 25.7 (br, $\mathrm{CH}_{2}-\eta^{2}$-allyl), $22.7\left(\mathrm{br}, \mathrm{CH}_{2} \mathrm{P}\right), 15.4$ $\left(\mathrm{d}, J_{\mathrm{C}, \mathrm{P}}=41 \mathrm{~Hz}, \mathrm{PMe}_{3}\right) .{ }^{11} \mathrm{~B}\left\{{ }^{1} \mathrm{H}\right\} \mathrm{NMR}\left(96 \mathrm{MHz}, \mathrm{C}_{6} \mathrm{D}_{6}, 25{ }^{\circ} \mathrm{C}\right) \delta-1.15$ (br s). MS (MALDITOF $\left.^{+}\right): m / z(\%): 615.1(40)\left[\mathrm{M}^{-} \text {allyl }\right]^{+}$. 
$\left[\operatorname{Ir}\left(\mathrm{K}^{2}-\mathbf{A}_{2} \mathbf{B P N}\right)(\mathbf{C O})(\mathbf{C l})(\mathbf{H}) \mathbf{P P h}_{3}\right]$ (15). A suspension of $\mathbf{1 3}(0.10 \mathrm{~g}, 0.12 \mathrm{mmol})$ in diethyl ether $(5 \mathrm{~mL})$ was treated with a diethyl ether solution of $\mathrm{HCl}(176 \mu \mathrm{L}, 0.67 \mathrm{M}, 0.12 \mathrm{mmol})$, that produced the immediate formation of a yellowish precipitate. The solution was stirred for 30 minutes, and then the solvent was removed to yield a pale yellow solid, that was filtered out and dried by vacuum. Yield: $0.10 \mathrm{~g}(98 \%)$. Anal. Calcd (\%) for $\mathrm{C}_{41} \mathrm{H}_{41} \mathrm{BClIrN}_{2} \mathrm{OP}_{2}$ (878.22): $\mathrm{C}$ 56.07, H 4.71, N 3.19; found: C 55.51, H 4.67, N 3.00. IR $\left(\mathrm{CDCl}_{3}\right): v(\mathrm{Ir}-\mathrm{H}) / \mathrm{cm}^{-1}: 2253(\mathrm{w})$, $v(\mathrm{CO}) / \mathrm{cm}^{-1}: 2058(\mathrm{~s}) .{ }^{1} \mathrm{H}$ NMR $\left(500 \mathrm{MHz}, \mathrm{C}_{6} \mathrm{D}_{6}, 25^{\circ} \mathrm{C}\right): \delta 7.84\left(\mathrm{~m}, 2 \mathrm{H}, \mathrm{H}^{o} \mathrm{PPh}_{2}\right), 7.63(\mathrm{~m}, 6 \mathrm{H}$, $\left.\mathrm{H}^{o} \mathrm{PPh}_{3}\right), 7.45(\mathrm{~d}, J=1.9 \mathrm{~Hz}, 2 \mathrm{H}, \mathrm{pz}), 7.37\left(\mathrm{~m}, 2 \mathrm{H}, \mathrm{H}^{o} \mathrm{PPh}_{2}\right), 6.96\left(\mathrm{~m}, 3 \mathrm{H}, \mathrm{H}^{m+p} \mathrm{PPh}_{2}+9 \mathrm{H}\right.$, $\left.\mathrm{H}^{m+p} \mathrm{PPh}_{3}\right), 6.86\left(\mathrm{~m}, 3 \mathrm{H}, \mathrm{H}^{m^{4}+p^{*}} \mathrm{PPh}_{2}\right), 6.06(\mathrm{~m}, 1 \mathrm{H})$ and $5.82(\mathrm{~m}, 1 \mathrm{H})(=\mathrm{CH}-\mathrm{allyl}), 5.66(\mathrm{t}, J=$ $1.8 \mathrm{~Hz}, 1 \mathrm{H}, \mathrm{pz}), 5.01(\mathrm{~m}, 2 \mathrm{H})$ and $4.87(\mathrm{~m}, 2 \mathrm{H})\left(=\mathrm{CH}_{2}\right.$-allyl), $2.52\left(\mathrm{~m}, 1 \mathrm{H}, \mathrm{CH}_{2}\right.$-allyl), 2.09 (dd, $\left.J=12.6,6.7 \mathrm{~Hz}, 1 \mathrm{H}, \mathrm{CH}_{2} \mathrm{P}\right), 1.94\left(\mathrm{~m}, 2 \mathrm{H} \mathrm{CH}_{2}\right.$-allyl $\left.+1 \mathrm{H}, \mathrm{CH}_{2} \mathrm{P}\right), 1.53\left(\mathrm{t}, J=9.8 \mathrm{~Hz}, 1 \mathrm{H}, \mathrm{CH}_{2^{-}}\right.$ allyl), -14.47 (t, $\left.J_{\mathrm{H}, \mathrm{P}}=12.0 \mathrm{~Hz}, 1 \mathrm{H}, \mathrm{Ir}-\mathrm{H}\right) .{ }^{31} \mathrm{P}\left\{{ }^{1} \mathrm{H}\right\}$ NMR $\left(202 \mathrm{MHz}, \mathrm{C}_{6} \mathrm{D}_{6}, 25^{\circ} \mathrm{C}\right): \mathrm{AB}$ spin

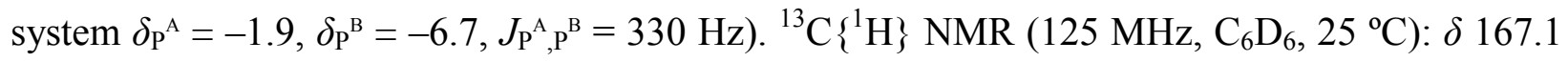
$\left(\mathrm{dd}, J_{\mathrm{C}, \mathrm{P}}=8,7 \mathrm{~Hz}, \mathrm{CO}\right), 144.1(\mathrm{pz}), 143.0$ and $142.7(=\mathrm{CH}-\mathrm{allyl}), 137.7(\mathrm{pz}), 137.2\left(\mathrm{~d}, J_{\mathrm{C}, \mathrm{P}}=43\right.$ $\left.\mathrm{Hz}, \mathrm{C}^{i} \mathrm{PPh}_{2}\right), 135.0\left(\mathrm{~d}, J_{\mathrm{C}, \mathrm{P}}=10 \mathrm{~Hz}, \mathrm{C}^{o} \mathrm{PPh}_{3}\right), 133.9\left(\mathrm{dd}, J_{\mathrm{C}, \mathrm{P}}=9,2 \mathrm{~Hz}\right)$ and $131.9\left(\mathrm{~d}, J_{\mathrm{C}, \mathrm{P}}=9\right.$ $\mathrm{Hz})\left(\mathrm{C}^{o} \mathrm{PPh}_{2}\right), 131.2\left(\mathrm{~d}, J_{\mathrm{C}, \mathrm{P}}=2 \mathrm{~Hz}, \mathrm{C}^{p} \mathrm{PPh}_{3}\right), 130.5$ and $130.2\left(\mathrm{~d}, J_{\mathrm{C}, \mathrm{P}}=2 \mathrm{~Hz}\right)\left(\mathrm{C}^{p} \mathrm{PPh}_{2}\right), 130.0$ $\left(\mathrm{d}, J_{\mathrm{C}, \mathrm{P}}=49 \mathrm{~Hz}, \mathrm{C}^{i} \mathrm{PPh}_{3}\right), 128.7\left(\mathrm{~d}, J_{\mathrm{C}, \mathrm{P}}=10 \mathrm{~Hz}, \mathrm{C}^{m} \mathrm{PPh}_{3}\right), 127.8\left(\mathrm{~m}, \mathrm{C}^{m} \mathrm{PPh}_{2}\right), 111.1$ and 110.3 (= $\mathrm{CH}_{2}$-allyl), 105.3 (pz), 34.9 (br) and 34.3 (br) $\left(\mathrm{CH}_{2}\right.$-allyl), 14.4 (br, $\left.\mathrm{CH}_{2} \mathrm{P}\right)$. MS (MALDI$\left.\mathrm{TOF}^{+}\right): m / z(\%): 837.2(60)[\mathrm{M}-\text { allyl }]^{+}$.

[Ir $\left\{\kappa^{3}-\left(\right.\right.$ allyl)B(CH$\left.\left.\left(\mathrm{CH}_{2} \mathrm{CHCH}_{3}\right)\left(\mathrm{CH}_{2} \mathrm{PPh}_{2}\right)(\mathrm{Pz})\right\}(\mathrm{Cl})(\mathrm{CO}) \mathrm{PMe}_{3}\right]$ (16). A diethyl ether solution of $\mathrm{HCl}(0.2 \mathrm{~mL}, 0.67 \mathrm{M}, 0.15 \mathrm{mmol})$ was added via microsyringe to a suspension of $\mathbf{1 4}(0.10 \mathrm{~g}$, $0.15 \mathrm{mmol})$ in diethyl ether $(5 \mathrm{~mL})$, affording instantly a yellowish precipitate. After 20 minutes of stirring, the supernatant liquid was removed via cannula and the solid was washed with cold 
diethyl ether $(5 \mathrm{~mL})$, and then dried under vacuum. Yield: $0.1 \mathrm{~g}(94 \%)$. Anal. Calcd (\%) for $\mathrm{C}_{26} \mathrm{H}_{35} \mathrm{BClIrN}_{2} \mathrm{OP}_{2}$ (692.01): C 45.13, H 5.10, N 4.05; found: $\mathrm{C} 44.67, \mathrm{H}$ 5.23, N 3.92. IR $\left(\mathrm{CDCl}_{3}\right): v(\mathrm{CO}) / \mathrm{cm}^{-1}: 2061$ (s). ${ }^{1} \mathrm{H}$ NMR $\left(300 \mathrm{MHz}, \mathrm{CDCl}_{3}, 25^{\circ} \mathrm{C}\right): \delta 8.17(\mathrm{~d}, J=2.3 \mathrm{~Hz}, 1 \mathrm{H}$, pz), $7.57\left(\mathrm{~m}, 4 \mathrm{H}, \mathrm{H}^{o+o^{\circ}} \mathrm{PPh}_{2}\right), 7.39\left(\mathrm{~m}, 3 \mathrm{H}, \mathrm{H}^{m+p} \mathrm{PPh}_{2}\right), 7.33(\mathrm{~m}, 1 \mathrm{H}, \mathrm{pz}), 7.15\left(\mathrm{~m}, 3 \mathrm{H}, \mathrm{H}^{m^{4}+p^{c}}\right.$ $\left.\mathrm{PPh}_{2}\right), 6.05(\mathrm{~m}, 1 \mathrm{H}, \mathrm{pz}), 6.04(\mathrm{~m}, 1 \mathrm{H},=\mathrm{CH}-\mathrm{allyl}), 4.83(\mathrm{dd}, J=15.0,3.0 \mathrm{~Hz}, 1 \mathrm{H})$ and $4.75(\mathrm{dd}, J$ $=9.0,3.0 \mathrm{~Hz}, 1 \mathrm{H})\left(=\mathrm{CH}_{2}\right.$-allyl $), 2.75\left(\mathrm{~m}, 1 \mathrm{H}, \mathrm{Ir}-\mathrm{CH}\left(\mathrm{CH}_{3}\right) \mathrm{CH}_{2}\right), 1.69(\mathrm{~d}, J=6.0 \mathrm{~Hz}, 3 \mathrm{H}, \mathrm{Ir}-$ $\left.\mathrm{CH}\left(\mathrm{CH}_{3}\right) \mathrm{CH}_{2}\right), 1.62\left(\mathrm{~m}, 1 \mathrm{H}, \mathrm{CH}_{2} \mathrm{P}\right), 1.56\left(\mathrm{~m}, 2 \mathrm{H}, \mathrm{CH}_{2}\right.$-allyl), $1.34\left(\mathrm{~d}, J_{\mathrm{H}, \mathrm{P}}=12.0 \mathrm{~Hz}, 9 \mathrm{H}, \mathrm{PMe}_{3}\right)$, $1.03\left(\mathrm{~m}, 1 \mathrm{H}, \mathrm{CH}_{2} \mathrm{P}\right), 0.60(\mathrm{~m}, 1 \mathrm{H})$ and $0.11(\mathrm{~m}, 1 \mathrm{H})\left(\mathrm{Ir}-\mathrm{CH}\left(\mathrm{CH}_{3}\right) \mathrm{CH}_{2}\right) \cdot{ }^{31} \mathrm{P}\left\{{ }^{1} \mathrm{H}\right\} \mathrm{NMR}(121$ MHz, $\left.\mathrm{CDCl}_{3}, 25^{\circ} \mathrm{C}\right): \delta-12.8\left(\mathrm{~d}, J_{\mathrm{P}, \mathrm{P}}=22 \mathrm{~Hz}\right),-46.4\left(\mathrm{~d}, J_{\mathrm{P}, \mathrm{P}}=22 \mathrm{~Hz}\right) \cdot{ }^{13} \mathrm{C}\left\{{ }^{1} \mathrm{H}\right\} \mathrm{NMR}(75 \mathrm{MHz}$ $\left.\mathrm{CDCl}_{3}, 25^{\circ} \mathrm{C}\right): \delta 168.1\left(\mathrm{dd}, J_{\mathrm{C}-\mathrm{P}}=132,9 \mathrm{~Hz}, \mathrm{CO}\right), 143.3\left(=\mathrm{CH}-\right.$ allyl), $142.2\left(\mathrm{~d}, J_{\mathrm{C}, \mathrm{P}}=2 \mathrm{~Hz}, \mathrm{pz}\right)$ $135.4\left(\mathrm{dd}, J_{\mathrm{C}, \mathrm{P}}=40,3 \mathrm{~Hz}, \mathrm{C}^{i} \mathrm{PPh}_{2}\right), 134.1\left(\mathrm{~d}, J_{\mathrm{C}, \mathrm{P}}=9 \mathrm{~Hz}, \mathrm{C}^{o} \mathrm{PPh}_{2}\right), 133.5\left(\mathrm{~d}, J_{\mathrm{C}, \mathrm{P}}=4 \mathrm{~Hz}, \mathrm{pz}\right)$, $132.7\left(\mathrm{~d}, J_{\mathrm{C}, \mathrm{P}}=9 \mathrm{~Hz}, \mathrm{C}^{o^{\circ}} \mathrm{PPh}_{2}\right), 131.5\left(\mathrm{~d}, J_{\mathrm{C}, \mathrm{P}}=55 \mathrm{~Hz}, \mathrm{C}^{i^{i}} \mathrm{PPh}_{2}\right), 130.3\left(\mathrm{~d}, J_{\mathrm{C}, \mathrm{P}}=2 \mathrm{~Hz}\right)$ and $129.8\left(\mathrm{~d}, J_{\mathrm{C}, \mathrm{P}}=2 \mathrm{~Hz}\right)\left(\mathrm{C}^{p+p^{c}} \mathrm{PPh}_{2}\right), 128.5\left(\mathrm{~d}, J_{\mathrm{C}, \mathrm{P}}=9 \mathrm{~Hz}\right)$ and $127.2\left(\mathrm{~d}, J_{\mathrm{C}, \mathrm{P}}=10 \mathrm{~Hz}\right)\left(\mathrm{C}^{m+m^{c}}\right.$ $\left.\mathrm{PPh}_{2}\right), 110.2\left(=\mathrm{CH}_{2}\right.$-allyl), $105.3(\mathrm{pz}), 37.2\left(\mathrm{Ir}-\mathrm{CH}\left(\mathrm{CH}_{3}\right) \mathrm{CH}_{2}\right), 37.0\left(\mathrm{br}, \mathrm{Ir}-\mathrm{CH}\left(\mathrm{CH}_{3}\right) \mathrm{CH}_{2}\right), 33.2$ (br, $\mathrm{CH}_{2}$-allyl), 16.4 (br, $\left.\mathrm{CH}_{2} \mathrm{P}\right), 15.2\left(\mathrm{Ir}-\mathrm{CH}\left(\mathrm{CH}_{3}\right) \mathrm{CH}_{2}\right), 14.6$ (d, $\left.J_{\mathrm{C}, \mathrm{P}}=41 \mathrm{~Hz}, \mathrm{PMe}_{3}\right) . \mathrm{MS}$ $\left(\mathrm{MALDI}-\mathrm{TOF}^{+}\right): m / z(\%): 614.9(20)\left[\mathrm{M}-\mathrm{PMe}_{3}\right]^{+}, 586.9(5)\left[\mathrm{M}-\mathrm{PMe}_{3}-\mathrm{CO}\right]^{+}$.

$\left[\operatorname{Ir}\left(\kappa^{3}-\mathbf{A}_{2} \mathbf{B P N}\right)(\mathbf{C O})\left(\mathbf{H}_{2} \mathbf{C}=\mathbf{C H}_{2}\right)\right]$ (17). Carbon monoxide was bubled through an orange solution of $3(0.10 \mathrm{~g}, 0.16 \mathrm{mmol})$ in diethyl ether $(12 \mathrm{~mL})$ for 20 minutes to yield a transparent yellow solution. Then, the solution was exposed to an ethylene atmosphere for 26 hours. The solvent was then evaporated and the oily residue was washed with hexanes to yield a pale yellow solid. It was filtered out and dried under vacuum. Yield: $0.070 \mathrm{~g} \mathrm{(69 \% ).} \mathrm{Anal.} \mathrm{Calcd} \mathrm{( \% )} \mathrm{for}$ $\mathrm{C}_{25} \mathrm{H}_{29} \mathrm{BIrN}_{2} \mathrm{OP}$ (607.52): C 49.43, H 4.81, N 4.61; found: $\mathrm{C} 49.52, \mathrm{H} 4.76, \mathrm{~N}$ 4.51. IR (ATR): $v(\mathrm{CO}) / \mathrm{cm}^{-1}: 2005$ (s). IR $\left(\mathrm{C}_{6} \mathrm{D}_{6}\right): v(\mathrm{CO}) / \mathrm{cm}^{-1}: 2013$ (s). ${ }^{1} \mathrm{H}$ NMR $\left(300 \mathrm{MHz}, \mathrm{C}_{6} \mathrm{D}_{6}, 25{ }^{\circ} \mathrm{C}\right): \delta$ 
$7.57\left(\mathrm{~m}, 2 \mathrm{H}, \mathrm{H}^{o} \mathrm{PPh}_{2}\right), 7.47(\mathrm{~d}, J=2.0 \mathrm{~Hz}, 1 \mathrm{H}, \mathrm{pz}), 7.07\left(\mathrm{~m}, 2 \mathrm{H}, \mathrm{H}^{m} \mathrm{PPh}_{2}\right), 6.94\left(1 \mathrm{H}, \mathrm{H}^{p} \mathrm{PPh}_{2}+\right.$ $\left.5 \mathrm{H}, \mathrm{H}^{o^{\prime}+m^{\prime}+p^{\prime}} \mathrm{PPh}_{2}\right), 6.40(\mathrm{~m}, 1 \mathrm{H},=\mathrm{CH}$-allyl $), 6.28(\mathrm{~d}, J=2.0 \mathrm{~Hz}, 1 \mathrm{H}, \mathrm{pz}), 5.69(\mathrm{t}, J=2.0 \mathrm{~Hz}$, $1 \mathrm{H}, \mathrm{pz}), 5.24(\mathrm{~d}, J=13.8 \mathrm{~Hz}, 1 \mathrm{H})$ and $5.16(\mathrm{~d}, J=10.2 \mathrm{~Hz}, 1 \mathrm{H})\left(=\mathrm{CH}_{2}\right.$-allyl $), 4.30(\mathrm{~m}, 1 \mathrm{H},=\mathrm{CH}-$ $\eta^{2}$-allyl), $3.67\left(\mathrm{~m}, 1 \mathrm{H},=\mathrm{CH}_{2}-\eta^{2}\right.$-allyl), $2.73(\mathrm{~m}, 2 \mathrm{H})$ and $2.47(\mathrm{~m}, 1 \mathrm{H})\left(\eta^{2}-\mathrm{H}_{2} \mathrm{C}=\mathrm{CH}_{2}\right), 2.33(\mathrm{dd}, J$ $=12.5,4.5 \mathrm{~Hz}, 1 \mathrm{H},=\mathrm{CH}_{2}-\eta^{2}$-allyl), $2.07\left(\mathrm{t}, J_{\mathrm{H}, \mathrm{H}}=9 \mathrm{~Hz}, 1 \mathrm{H}, \mathrm{CH}_{2}-\eta^{2}\right.$-allyl), $1.91\left(\mathrm{~m}, 2 \mathrm{H}, \mathrm{CH}_{2}-\right.$ allyl), $1.69\left(\mathrm{t}, J_{\mathrm{H}, \mathrm{P}}=14.6 \mathrm{~Hz}, 1 \mathrm{H}, \mathrm{CH}_{2} \mathrm{P}\right), 1.33\left(\mathrm{~m}, 1 \mathrm{H}, \eta^{2}-\mathrm{H}_{2} \mathrm{C}=\mathrm{CH}_{2}\right), 1.20\left(\mathrm{t}, J_{\mathrm{H}, \mathrm{P}}=14.6 \mathrm{~Hz}, 1 \mathrm{H}\right.$, $\left.\mathrm{CH}_{2} \mathrm{P}\right), 0.86$ (m, 1H, $\mathrm{CH}_{2}-\eta^{2}$-allyl). ${ }^{31} \mathrm{P}\left\{{ }^{1} \mathrm{H}\right\}$ NMR $\left(121 \mathrm{MHz}, \mathrm{C}_{6} \mathrm{D}_{6}, 25{ }^{\circ} \mathrm{C}\right): \delta-7.0(\mathrm{~s}) .{ }^{13} \mathrm{C}\left\{{ }^{1} \mathrm{H}\right\}$ $\operatorname{NMR}\left(75 \mathrm{MHz}, \mathrm{C}_{6} \mathrm{D}_{6}, 25^{\circ} \mathrm{C}\right): \delta 166.0\left(\mathrm{~d}, J_{\mathrm{C}, \mathrm{P}}=6 \mathrm{~Hz}, \mathrm{CO}\right), 143.1(=\mathrm{CH}-\mathrm{allyl}), 138.4\left(\mathrm{~d}, J_{\mathrm{C}, \mathrm{P}}=\right.$ $\left.44 \mathrm{~Hz}, \mathrm{C}^{i} \mathrm{PPh}_{2}\right), 138.0\left(\mathrm{~d}, J_{\mathrm{C}, \mathrm{P}}=43 \mathrm{~Hz}, \mathrm{C}^{i^{\prime}} \mathrm{PPh}_{2}\right), 134.2\left(\mathrm{~d}, J_{\mathrm{C}, \mathrm{P}}=8 \mathrm{~Hz}, \mathrm{pz}\right), 132.0(\mathrm{pz}), 131.6$ (m, $\left.\mathrm{C}^{o+o^{\prime}} \mathrm{PPh}_{2}\right), 129.7\left(\mathrm{C}^{p} \mathrm{PPh}_{2}\right), 129.0\left(\mathrm{C}^{m+m^{\prime}+p^{\prime}} \mathrm{PPh}_{2}\right), 111.4$ (= $\mathrm{CH}_{2}$-allyl), 104.8 (pz), 68.7 (d, $J_{\mathrm{C}, \mathrm{P}}=4 \mathrm{~Hz},=\mathrm{CH}-\eta^{2}$-allyl $), 41.2\left(\mathrm{~d}, J_{\mathrm{C}, \mathrm{P}}=9 \mathrm{~Hz},=\mathrm{CH}_{2}-\eta^{2}\right.$-allyl $), 34.6\left(\mathrm{br}, \mathrm{CH}_{2}\right.$-allyl $), 33.8\left(\mathrm{~d}, J_{\mathrm{C}, \mathrm{P}}\right.$ $=6 \mathrm{~Hz})$ and $28.0\left(\eta^{2}-\mathrm{H}_{2} \mathrm{C}=\mathrm{CH}_{2}\right), 25.6\left(\mathrm{br}, \mathrm{CH}_{2}-\eta^{2}\right.$-allyl $), 18.4\left(\mathrm{br}, \mathrm{CH}_{2} \mathrm{P}\right) . \mathrm{MS}\left(\mathrm{MALDI}-\mathrm{TOF}^{+}\right)$: $m / z(\%): 539.2(40)\left[\mathrm{M}-\text { allyl- } \mathrm{CO} / \mathrm{C}_{2} \mathrm{H}_{4}\right]^{+}$.

[Ir( $\left.\left.\boldsymbol{K}^{3}-\mathbf{A}_{2} \mathbf{B P N}\right)(\mathbf{C O})(\mathbf{d m a d})\right]$ (18). Solid [Ir(acac)(cod) $](0.084 \mathrm{~g}, 0.21 \mathrm{mmol})$ was added to a suspensión of $1(0.101 \mathrm{~g}, 0.21 \mathrm{mmol})$ in diethyl ether. After 30 minutes of stirring, the suspension was filtered through a pad of celite, and then carbon monoxide was bubbled to give a bright yellow solution. Then $\mathrm{MeO}_{2} \mathrm{CC} \equiv \mathrm{CCO}_{2} \mathrm{Me}(51 \mu \mathrm{l}, 0.42 \mathrm{mmol})$ was added via microsyringe. The resulting light yellow solution was stirred for 20 more minutes. Concentration to ca. $0.5 \mathrm{~mL}$ and addition of hexanes yielded an orange solid, which was filtered out and dried under vacuum. Yield: $0.06 \mathrm{~g}(41 \%)$. Anal. Calcd (\%) for $\mathrm{C}_{29} \mathrm{H}_{31} \mathrm{BIrN}_{2} \mathrm{O}_{5} \mathrm{P}$ (721.57): C 48.27, $\mathrm{H}$ 4.33, N 3.88; found: C 48.05, H 4.11, N 3.76. IR (ATR): $v(\mathrm{CO}) / \mathrm{cm}^{-1}: 2032(\mathrm{~s}), v(\mathrm{C}=\mathrm{O}) / \mathrm{cm}^{-1}$ : 1699 (s). IR (toluene): $v(\mathrm{CO}) / \mathrm{cm}^{-1}: 2040$ (s), $v(\mathrm{C}=\mathrm{O}) / \mathrm{cm}^{-1}: 1709$ (s). ${ }^{1} \mathrm{H}$ NMR (300 MHz, $\mathrm{C}_{6} \mathrm{D}_{6}$, $\left.25^{\circ} \mathrm{C}\right): \delta 7.82(\mathrm{~d}, J=2.4 \mathrm{~Hz}, 1 \mathrm{H}, \mathrm{pz}), 7.74\left(\mathrm{~m}, 2 \mathrm{H}, \mathrm{H}^{o} \mathrm{PPh}_{2}\right), 7.34$ (d, $\left.J=2.3 \mathrm{~Hz}, 1 \mathrm{H}, \mathrm{pz}\right), 7.10$ 
(m, 2H, $\left.\mathrm{H}^{m} \mathrm{PPh}_{2}\right), 7.01\left(\mathrm{~m}, 1 \mathrm{H}, \mathrm{H}^{p} \mathrm{PPh}_{2}\right), 6.83\left(\mathrm{~m}, 5 \mathrm{H}, \mathrm{H}^{o^{\prime}+m^{\prime}+p^{\prime}} \mathrm{PPh}_{2}\right), 6.24(\mathrm{~m}, 1 \mathrm{H},=\mathrm{CH}-$ allyl), $5.85(\mathrm{t}, J=2.4 \mathrm{~Hz}, 1 \mathrm{H}, \mathrm{pz}), 5.12(\mathrm{~m}, 1 \mathrm{H})$ and $5.08(\mathrm{~m}, 1 \mathrm{H})\left(=\mathrm{CH}_{2}\right.$-allyl $), 4.36\left(\mathrm{~m}, 1 \mathrm{H},=\mathrm{CH}-\eta^{2}-\right.$ allyl), $4.26\left(\mathrm{~m}, 1 \mathrm{H},=\mathrm{CH}_{2}-\eta^{2}\right.$-allyl), $3.67(\mathrm{~s}, 3 \mathrm{H})$ and $3.45(\mathrm{~s}, 3 \mathrm{H})\left(\mathrm{OCH}_{3}\right), 3.30\left(\mathrm{~m}, 1 \mathrm{H},=\mathrm{CH}_{2}-\right.$ $\eta^{2}$-allyl), $2.06\left(\mathrm{~m}, 1 \mathrm{H}, \mathrm{CH}_{2}-\eta^{2}\right.$-allyl), $1.91\left(\mathrm{t}, J_{\mathrm{H}, \mathrm{P}}=14.1 \mathrm{~Hz}, 1 \mathrm{H}, \mathrm{CH}_{2} \mathrm{P}\right), 1.70\left(\mathrm{~m}, 2 \mathrm{H}, \mathrm{CH}_{2}-\right.$ allyl), 0.85 (m, 1H, $\left.\mathrm{CH}_{2} \mathrm{P}\right), 0.60$ (m, 1H, $\mathrm{CH}_{2}-\eta^{2}$-allyl). ${ }^{31} \mathrm{P}\left\{{ }^{1} \mathrm{H}\right\}$ NMR $\left(121 \mathrm{MHz}, \mathrm{C}_{6} \mathrm{D}_{6}, 2{ }^{\circ} \mathrm{C}\right)$ : $\delta-3.1(\mathrm{~s}) .{ }^{13} \mathrm{C}\left\{{ }^{1} \mathrm{H}\right\} \operatorname{NMR}\left(75 \mathrm{MHz}, \mathrm{C}_{6} \mathrm{D}_{6}, 25{ }^{\circ} \mathrm{C}\right): \delta 162.7\left(\mathrm{~d}, J_{\mathrm{C}, \mathrm{P}}=5 \mathrm{~Hz}, \mathrm{C}=\mathrm{O}\right), 162.1\left(\mathrm{~d}, J_{\mathrm{C}, \mathrm{P}}=\right.$ $6 \mathrm{~Hz}, \mathrm{CO}), 162.0\left(\mathrm{~d}, J_{\mathrm{C}, \mathrm{P}}=8 \mathrm{~Hz}, \mathrm{C}=\mathrm{O}\right), 142.6(=\mathrm{CH}-\mathrm{allyl}), 138.0\left(\mathrm{~d}, J_{\mathrm{C}, \mathrm{P}}=50 \mathrm{~Hz}, \mathrm{C}^{i} \mathrm{PPh}_{2}\right)$, 136.5 and $135.3(\mathrm{pz}), 135.1\left(\mathrm{~d}, J_{\mathrm{C}-\mathrm{P}}=48 \mathrm{~Hz}, \mathrm{C}^{i} \mathrm{PPh}_{2}\right), 131.7\left(\mathrm{~d}, J_{\mathrm{C}-\mathrm{P}}=11 \mathrm{~Hz}, \mathrm{C}^{o+o^{\prime}} \mathrm{PPh}_{2}\right), 130.3$ $\left(\mathrm{d}, J_{\mathrm{C}-\mathrm{P}}=2 \mathrm{~Hz}\right)$ and $129.7\left(\mathrm{~d}, J_{\mathrm{C}-\mathrm{P}}=2 \mathrm{~Hz}\right)\left(\mathrm{C}^{p} \mathrm{PPh}_{2}\right), 128.8\left(\mathrm{~d}, J_{\mathrm{C}-\mathrm{P}}=10 \mathrm{~Hz}\right)$ and $128.1(\mathrm{~d}$, hidden behind solvent signal) $\left(\mathrm{C}^{m} \mathrm{PPh}_{2}\right), 111.7\left(=\mathrm{CH}_{2}\right.$-allyl), $105.0(\mathrm{pz}), 91.5\left(\mathrm{~d}, J_{\mathrm{C}, \mathrm{P}}=7 \mathrm{~Hz}\right)$ and 86.9 $\left(\mathrm{d}, J_{\mathrm{C}, \mathrm{P}}=40 \mathrm{~Hz}\right)(\mathrm{C} \equiv \mathrm{C}), 82.1\left(=\mathrm{CH}-\eta^{2}\right.$-allyl $), 52.3$ and $52.1\left(\mathrm{OCH}_{3}\right), 48.9\left(\mathrm{~d}, J_{\mathrm{C}-\mathrm{P}}=5 \mathrm{~Hz},=\mathrm{CH}_{2}-\right.$ $\eta^{2}$-allyl), 34.3 (br, $\mathrm{CH}_{2}$-allyl), 26.1 (br, $\mathrm{CH}_{2}-\eta^{2}$-allyl), 17.0 (br, $\left.\mathrm{CH}_{2} \mathrm{P}\right)$. MS (MALDI-TOF ${ }^{+}$): $m / z$ (\%): $663.4(85)[\mathrm{M}-\mathrm{COOMe}]^{+}$.

$\left[\operatorname{Ir}\left(\kappa^{2}-\mathbf{A}_{2} \mathbf{B P N}\right)\left(\mathbf{C N} \mathbf{B u}_{2} \mathbf{2}(\mathbf{d m a d})\right] \mathbf{( 1 9 )}\right.$. To a yellow solution of $5(0.110 \mathrm{~g}, 0.149 \mathrm{mmol})$ in THF $(8 \mathrm{~mL})$, dmad $(20 \mu \mathrm{l}, 0.164 \mathrm{mmol})$ was added dropwise via microsyringe, to give a dark orange solution. After one hour of stirring the solvent was evaporated to give an orange residue, which after treatment with hexanes yielded a creamy white solid, which was filtered out and dried under vacuum. Yield $0.11 \mathrm{~g}(86 \%)$. \%). Anal. Calcd (\%) for $\mathrm{C}_{38} \mathrm{H}_{49} \mathrm{BIrN}_{4} \mathrm{O}_{4} \mathrm{P}$ (859.83): 53.08, H 5.74, N 6.52; found C 53.01, H 5.65, N 6.45 IR (ATR): $v(\mathrm{CN}) / \mathrm{cm}^{-1}: 2196$ (s), 2164 (s), $v(\mathrm{C}=\mathrm{O}) / \mathrm{cm}^{-1}: 1746(\mathrm{~s}), 1686(\mathrm{~s}) .{ }^{1} \mathrm{H}$ NMR $\left(400 \mathrm{MHz}, \mathrm{C}_{6} \mathrm{D}_{6}, 25^{\circ} \mathrm{C}\right): \delta 8.29\left(\mathrm{~m}, 2 \mathrm{H}, \mathrm{H}^{o} \mathrm{PPh}_{2}\right)$, $8.17(\mathrm{~d}, J=1.2 \mathrm{~Hz}, 1 \mathrm{H}, \mathrm{pz}), 7.58(\mathrm{~d}, J=1.6 \mathrm{~Hz}, 1 \mathrm{H}, \mathrm{pz}), 7.52\left(\mathrm{~m}, 2 \mathrm{H}, \mathrm{H}^{o^{\prime}} \mathrm{PPh}_{2}\right), 7.33(\mathrm{~m}, 2 \mathrm{H}$, $\left.\mathrm{H}^{m} \mathrm{PPh}_{2}\right), 7.11\left(\mathrm{~m}, 1 \mathrm{H}, \mathrm{H}^{p} \mathrm{PPh}_{2}\right) 7.04\left(\mathrm{~m}, 3 \mathrm{H}, \mathrm{H}^{m^{4}+p^{c}} \mathrm{PPh}_{2}\right), 6.34(\mathrm{~m}, 1 \mathrm{H},=\mathrm{CH}-$ allyl), $5.99(\mathrm{t}, J=$ $2 \mathrm{~Hz}, 1 \mathrm{H}, \mathrm{pz}), 5.68(\mathrm{~m}, 1 \mathrm{H},=\mathrm{CH}-\mathrm{allyl}), 5.21(\mathrm{~d}, J=14.4 \mathrm{~Hz}, 1 \mathrm{H})$ and $5.12(\mathrm{~d}, J=10.0 \mathrm{~Hz}, 1 \mathrm{H})$ 
$\left(=\mathrm{CH}_{2}\right.$-allyl), $4.81(\mathrm{~d}, J=10.0 \mathrm{~Hz}, 1 \mathrm{H})$ and $4.74(\mathrm{~d}, J=17.2 \mathrm{~Hz}, 1 \mathrm{H})\left(=\mathrm{CH}_{2}\right.$-allyl $), 3.58(\mathrm{~s}, 3 \mathrm{H})$ and $3.53(\mathrm{~s}, 3 \mathrm{H})\left(\mathrm{OCH}_{3}\right), 2.35\left(\mathrm{~m}, 1 \mathrm{H}, \mathrm{CH}_{2} \mathrm{P}\right), 2.00\left(\mathrm{~m}, 3 \mathrm{H}, \mathrm{CH}_{2}\right.$-allyl), $1.76\left(\mathrm{~m}, 1 \mathrm{H}, \mathrm{CH}_{2} \mathrm{P}\right), 1.13$ (m, 1H, $\mathrm{CH}_{2}$-allyl), $0.86(\mathrm{~s}, 9 \mathrm{H})$ and $0.69(\mathrm{~s}, 9 \mathrm{H})\left(\mathrm{CN}^{t} \mathrm{Bu}\right) .{ }^{31} \mathrm{P}\left\{{ }^{1} \mathrm{H}\right\} \mathrm{NMR}\left(161 \mathrm{MHz}, \mathrm{C}_{6} \mathrm{D}_{6}, 25\right.$ $\left.{ }^{\circ} \mathrm{C}\right): \delta-6.4(\mathrm{~s}) .{ }^{13} \mathrm{C}\left\{{ }^{1} \mathrm{H}\right\}$ NMR $\left(100 \mathrm{MHz}, \mathrm{C}_{6} \mathrm{D}_{6}, 25{ }^{\circ} \mathrm{C}\right): \delta 166.5\left(\mathrm{~d}, J_{\mathrm{C}, \mathrm{P}}=12 \mathrm{~Hz},\right)$ and $163.3(\mathrm{~d}$, $\left.J_{\mathrm{C}, \mathrm{P}}=10 \mathrm{~Hz}\right)\left(C \mathrm{~N}^{t} \mathrm{Bu}\right), 152.0$ and $151.9(\mathrm{C}=\mathrm{O}), 146.0(\mathrm{pz}), 144.3$ and $144.1(=\mathrm{CH}-\mathrm{allyl}), 143.5$ $\left(\mathrm{d}, J_{\mathrm{C}, \mathrm{P}}=42 \mathrm{~Hz}, \mathrm{C}^{i} \mathrm{PPh}_{2}\right), 135.4\left(\mathrm{~d}, J_{\mathrm{C}, \mathrm{P}}=13 \mathrm{~Hz}, \mathrm{C}^{o} \mathrm{PPh}_{2}\right), 135.2\left(\mathrm{~d}, J_{\mathrm{C}, \mathrm{P}}=50 \mathrm{~Hz}, \mathrm{C}^{i^{i}} \mathrm{PPh}_{2}\right)$, $134.7(\mathrm{pz}), 131.4\left(\mathrm{~d}, J_{\mathrm{C}, \mathrm{P}}=9 \mathrm{~Hz}, \mathrm{C}^{o^{*}} \mathrm{PPh}_{2}\right), 130.3\left(\mathrm{~d}, J_{\mathrm{C}, \mathrm{P}}=2 \mathrm{~Hz}, \mathrm{C}^{p} \mathrm{PPh}_{2}\right), 128.1(\mathrm{~m}$, $\left.\mathrm{PPh}_{2}{ }^{m+m^{4}+p}\right), 110.6$ and $109.2\left(=\mathrm{CH}_{2}\right.$-allyl), $105.3\left(\mathrm{~d}, J_{\mathrm{C}, \mathrm{P}}=6 \mathrm{~Hz}, \mathrm{C} \equiv \mathrm{C}\right), 105.0(\mathrm{pz}), 101.6\left(\mathrm{~d}, J_{\mathrm{C}, \mathrm{P}}\right.$ $=66 \mathrm{~Hz}, \mathrm{C} \equiv \mathrm{C}), 57.9$ and $57.2\left(\mathrm{CMe}_{3}\right), 51.8$ and $51.7\left(\mathrm{OCH}_{3}\right), 34.9$ and $31.8\left(\mathrm{br}, \mathrm{CH}_{2}\right.$-allyl), 30.0 and $29.9\left(\mathrm{CMe}_{3}\right), 17.5$ (br, $\left.\mathrm{CH}_{2} \mathrm{P}\right)$. MS (MALDI-TOF $\left.{ }^{+}\right): m / z(\%): 677.4$ (74) [M-dmad-allyl] ${ }^{+}$.

DFT geometry optimizations. The computational method used was density functional theory (DFT) with the B3LYP exchange-correlation functional, ${ }^{48}$ using the Gaussian $09^{49}$ program package. The basis sets used for the full optimization of the structures and for the frequency calculations were LanL2TZ(f) effective core potential for the metal atoms, and 6-31G(d,p) for the remaining atoms.

X-ray diffraction studies on $\mathbf{3} \cdot 0.5\left(\mathrm{C}_{6} \mathrm{H}_{14}\right), \mathbf{8}, \mathbf{1 1}$, and $\cdot \mathbf{1 8} \cdot 0.5\left(\mathrm{C}_{6} \mathrm{H}_{14}\right)$. Selected crystallographic data for these complexes can be found in Table 6 . Intensity measurements were collected with a Smart Apex diffractometer, with graphite-monochromated $\mathrm{MoK}_{\alpha}$ radiation. A semi-empirical absorption correction was applied to each data set, with the multi-scan ${ }^{50}$ methods. All nonhydrogen atoms were refined with anisotropic displacement parameters except one disordered hexane solvent molecule in $\mathbf{1 8} \cdot 0.5\left(\mathrm{C}_{6} \mathrm{H}_{14}\right)$ which was refined with isotropic displacement parameters and with geometrical restraints. The hydrogen atoms were placed at calculated positions and were refined isotropically in riding mode. The structures were solved by direct 
methods and refined by full-matrix least-squares with the program SHELX97 $7^{51}$ in the WINGX ${ }^{52}$ package. 
Table 6. Selected Crystal, Measurement, and Refinement Data for Compounds $\mathbf{3} 0.5\left(\mathrm{C}_{6} \mathrm{H}_{14}\right)$, 8 , 11, and $\cdot 18 \cdot 0.5\left(\mathrm{C}_{6} \mathrm{H}_{14}\right)$.

\begin{tabular}{|c|c|c|c|c|}
\hline & $3 \cdot 0.5\left(\mathrm{C}_{6} \mathrm{H}_{14}\right)$ & 8 & 11 & $\mathbf{1 8} \cdot 0.5\left(\mathrm{C}_{6} \mathrm{H}_{14}\right)$ \\
\hline Formula & $\mathrm{C}_{30} \mathrm{H}_{37} \mathrm{BIrN}{ }_{2} \mathrm{P} \cdot 0.5\left(\mathrm{C}_{6} \mathrm{H}_{14}\right)$ & $\mathrm{C}_{46} \mathrm{H}_{50} \mathrm{~B}_{2} \mathrm{~N}_{4} \mathrm{O}_{2} \mathrm{P}_{2} \mathrm{Rh}_{2}$ & $\mathrm{C}_{41} \mathrm{H}_{40} \mathrm{BN}_{2} \mathrm{OP}_{2} \mathrm{Rh}$ & $\mathrm{C}_{29} \mathrm{H}_{31} \mathrm{BIrNO}_{5} \mathrm{P} \cdot 0.5\left(\mathrm{C}_{6} \mathrm{H}_{14}\right)$ \\
\hline formula weight & 702.68 & 980.28 & 752.41 & 764.62 \\
\hline Colour & pale-yellow & yellow & yellow & colourless \\
\hline crystal system & orthorhombic & monoclinic & monoclinic & monoclinic \\
\hline space group & Pbca & $\mathrm{P} 2(1) / \mathrm{n}$ & $\mathrm{P} 2(1) / \mathrm{n}$ & $\mathrm{P} 2(1) / \mathrm{c}$ \\
\hline $\mathrm{a}[\AA]$ & $10.856(5)$ & 11.9199(19) & $11.203(2)$ & $18.5058(18)$ \\
\hline $\mathrm{b}[\AA]$ & $16.608(7)$ & $16.647(3)$ & $24.429(4)$ & $9.3837(9)$ \\
\hline$c[\AA]$ & $32.292(12)$ & $22.872(4)$ & $13.786(2)$ & $18.6119(18)$ \\
\hline$\beta\left[^{\circ}\right]$ & 90 & $104.359(3)$ & $102.177(3)$ & $90.491(2)$ \\
\hline$V\left[\AA^{3}\right]$ & $5822(4)$ & $4396.6(12)$ & $3688.0(10)$ & $3231.9(5)$ \\
\hline Z & 8 & 4 & 4 & 4 \\
\hline$F(000)$ & 2824 & 2000 & 1552 & 1524 \\
\hline$\rho_{\text {calcd }}\left[\mathrm{g} \mathrm{cm}^{-3}\right]$ & 1.603 & 1.481 & 1.355 & 1.571 \\
\hline$\mu\left(\mathrm{mm}^{-1}\right)$ & 4.667 & 0.866 & 0.584 & 4.222 \\
\hline crystal size [mm] & $0.13 \times 0.05 \times 0.04$ & $0.11 \times 0.05 \times 0.04$ & $0.14 \times 0.11 \times 0.07$ & $0.05 \times 0.04 \times 0.02$ \\
\hline temperature $[\mathrm{K}]$ & $100(2)$ & $100(2)$ & $100(2)$ & $100(2)$ \\
\hline$\theta$ limits $\left[{ }^{\circ}\right]$ & 27.27 & 26.00 & 26.00 & 25.20 \\
\hline collected reflns. & 33914 & 25837 & 21901 & 24471 \\
\hline unique reflns. (Rint) & $6499(0.0982)$ & $8645(0.0955)$ & $7220(0.0546)$ & $5818(0.0820)$ \\
\hline reflns. with $I>2 \sigma(I)$ & 4686 & 6354 & 5300 & 4237 \\
\hline parameters/restraints & $344 / 0$ & $523 / 0$ & $433 / 0$ & $373 / 27$ \\
\hline $\mathrm{R}_{1}($ on $\mathrm{F}, \mathrm{I}>2 \sigma(\mathrm{I}))$ & 0.0483 & 0.0567 & 0.0407 & 0.0402 \\
\hline $\mathrm{wR}_{2}\left(\right.$ on $F^{2}$, all data $)$ & 0.0898 & 0.1014 & 0.0939 & 0.0896 \\
\hline $\max . / \min . \Delta \rho\left[\mathrm{e} \AA^{-3}\right]$ & $1.129 /-1.808$ & $0.730 /-0.844$ & $0.710 /-0.360$ & 1.030 \\
\hline goodness of fit & 1.055 & 1.070 & 0.998 & $1.521 /-0.845$ \\
\hline
\end{tabular}

Supporting Information. Full ORTEP diagrams, selected spectroscopic data, Van't Hoff plotter, atomic coordinates for calculated DFT structures, complete reference 39, and a CIF file 
giving details of the $\mathrm{X}$-ray crystal structures of $\mathbf{3} \cdot 0.5\left(\mathrm{C}_{6} \mathrm{H}_{14}\right), \mathbf{8}, \mathbf{1 1}$, and $\mathbf{1 8} \cdot 0.5\left(\mathrm{C}_{6} \mathrm{H}_{14}\right)$. This material is available free of charge via the Internet at http://pubs.acs.org.

Corresponding Author. *E-mail: ctejel@unizar.es (C.T.), Tel: +34-976 762285. Fax: +34976 761187, E-mail: mcasado@unizar.es (M.A.C.)

Funding Sources. MICINN/FEDER (Project CTQ2011-22516, Spain) and Gobierno de Aragón (Group E70, Spain).

Notes. The authors declare no competing financial interest.

Acknowledgments. This research was supported by the MICINN/FEDER (Project CTQ201122516, Spain), Gobierno de Aragón (GA)/FSE (E70), and GA-La Caixa (2012/GA LC 057). The generous allocation of computational resources of the Centro de Supercomputación de Galicia (CESGA) is gratefully appreciated. A.L.S. thanks MICINN/FEDER for a fellowship.

\section{References}

(1) Morales-Morales, D.; Jensen, C. M. The Chemistry of Pincer Compounds; Elsevier: Amsterdam, 2007.

(2) See for example (a) Schneider, S.; Meiners, J.; Askevold, B. Eur. J. Inorg. Chem. 2012, 412-429. (b) Choi, J.; MacArthur, A. M. R.; Brookhart, M.; Goldman, A. S. Chem. Rev. 2011, 111, 1761-1779. (c) Selander, N.; Szabó, K. J. Chem. Rev. 2011, 111, 2048-2076. (d) Bernskoetter, W. H.; Schauer, C. K.; Goldberg, K. I.; Brookhart, M. Science 2009, 326, 553556. (e) Zhao, J.; Goldman, A. S.; Hartwig, J. F. Science 2005, 307, 1080-1082.

(3) Pettinari, C. Scorpionates II: Chelating Borate Ligands; Imperial College Press: London, 2008. 
(4) (a) Trofimenko, S. Scorpionates - The Coordination Chemistry of Polypyrazolylborate Ligands; Imperial College Press: London, 1999. (b) Trofimenko, S. J. Chem. Ed. 2005, 82, $1715-1720$.

(5) (a) Valpuesta, J. E. C.; Álvarez, E.; López-Serrano, J.; Maya, C.; Carmona, E. Chem. Eur. J. 2012, 18, 13149-13159. (b) Conejero, S.; Esqueda, A. C.; Valpuesta, J. E. V.; Álvarez, E.; Maya, C. Inorg. Chim. Acta 2011, 369, 165-172. (c) Pettinari, R.; Pettinari, C.; Marchetti, F.; Gobetto, R.; Nervi, C.; Chierotti, M. R.; Chan, E. J.; Skelton, B. W.; White, A. H. Inorg. Chem. 2010, 49, 11205-11215. (d) Adams, C. J.; Anderson, K. M.; Charmant, J. P. H.; Connelly, N. G.; Field, B. A.; Hallett, A. J.; Horne, M. Dalton Trans. 2008, 2680-2692. (e) Trofimenko, S.; Calabrese, J. C.; Thompson, J. S. Inorg. Chem. 1987, 26, 1507-1514.

(6) See for example: (a) Choi, G.; Morris, J.; Brennessel, W. W.; Jones, W. D. J. Am. Chem. Soc. 2012, 134, 9276-9284. (b) Frauhiger, B. E.; Ondisco, M. T.; White, P. S.; Templeton, J. L. J. Am. Chem. Soc. 2012, 134, 8902-8910. (c

E.; Alvarado-Rodríguez, J. G.; Paneque, M.; Poveda, M. L. Organometallics 2012, 31, 3185-3198. (d - _ E.; Paneque, M.; Poveda, M.

L. Organometallics 2012, 31, 716-721. (e) Conejero, S.; López-Serrano, J.; Paneque, M.; Petronilho, A.; Poveda, M. L.; Vattier, F.; Álvarez, E.; Carmona, E. Chem. Eur. J. 2012, 18, 4644-4664. (f) Castro-Rodrigo , E. Organometallics

2012, 31, 1991-2000. (g) Conejero, S.; Maya, C.; Paneque, M.; Petronilho, A.; Poveda, M. L.; Vattier, F.; Alvarez, E.; Carmona, E.; Laguna, A.; Crespo, O. Dalton Trans. 2012, 41, 14126-14136. (h) Paneque, M.; Poveda, M. L.; Rendón, N. Eur. J. Inorg. Chem. 2011, 19-33. (i) Bajo, S.; Esteruelas, M. A.; López, A. M.; Oñate, E. Organometallics 2011, 30, 5710-5715. (j) Evans, M. E.; Jones, W. D. Organometallics 2011, 30, 3371-3377. (k) Hernández, Y. A.; 
López-Serrano, J.; Paneque, M.; Poveda, M. L.; Vattier, F.; Salazar, V.; Álvarez, E.; Carmona, E. Chem. Eur. J. 2011, 17, 9302-9305. (1) Tanabe, T.; Evans, M. E.; Brennessel, W. W.; Jones, W. D. Organometallics 2011, 30, 834-843. (m) Cristobal, C.; García-Rubin, S.; Hernández, Y. A.; López-Serrano, J.; Paneque, M.; Posadas, C. M.; Poveda, M. L.; Rendón, N.; Alvarez, E. Organometallics 2010, 29, 5744-5747. (n) Evans, M. E.; Li, T.; Jones, W. D. J. Am. Chem. Soc. 2010, 132, 16278-16284. (o) Engelman, K. L.; White, P. S.; Templeton, J. L. Organometallics 2010, 29, 4943-4949. (p) Castro-Rodrigo, R.; Esteruelas, M. A.; López, A. M.; Mozo, S.; Oñate, E. Organometallics 2010, 29, 4071-4079. (q) Conejero, S.; Paneque, M.; Poveda, M. L.; Santos, L. L.; Carmona, E. Acc. Chem. Res. 2010, 43, 572-580. (r) Álvarez, E.; Hernández, Y. A.; López-Serrano, J.; Maya, C.; Paneque,M.; Petronilho, A.; Poveda, M. L.; Salazar, V.; Vattier, F.; Carmona, E. Angew. Chem. Int. Ed. 2010, 49, 3496-3499. (s) Castro-Rodrigo, R.; Esteruelas, M. A.; López, A. M.; López, F.; Mascareñas, J. L.; Oliván, M.; Oñate, E.; Saya, L.; Villarino, L. J. Am. Chem. Soc. 2010, 132, 454-455.

(7) (a) Morawitz, T.; Zhang, F.; Bolte, M.; Bats, J. W.; Lerner, H.-W.; Wagner, M. Organometallics 2008, 27, 5067-5074. (b) Reger, D. L.; Watson, R. P.; Gardinier, J. R.; Smith, M. D.; Pellechia, P. J. Inorg. Chem. 2006, 45, 10088-10097. (c) Ilkhechi, A. H.; Mercero, J. M.; Silanes, I.; Bolte, M.; Scheibitz, M.; Lerner, H.-W.; Ugalde, J. M.; Wagner, M. J. Am. Chem. Soc. 2005, 127, 10656-10666.

(8) Reger, D. L.; Gardinier, J. R.; Gemmill, W. R.; Smith, M. D.; Shahin, A. M.; Long, G. J.; Rebbouh, L.; Grandjean, F. J. Am. Chem. Soc. 2005, 127, 2303-2316.

(9) Camerano, J. A.; Casado, M. A.; Ciriano, M. A.; Oro, L. A. Dalton Trans. 2006, 52875293 
(10) See for recent examples: (a) Joslin, E. E.; McMullin, C. L.; Gunnoe, T. B.; Cundari, T. R.; Sabat, M.; Myers, W. H. Organometallics 2012, 31, 6851-6860. (b) Lo, Y. -H.; Wang, T. -H.; Lee, C. -Y.; Feng, Y. -H. Organometallics 2012, 31, 6887-6899. (c) Hu, T. C; Hsiao, P. I.; Wang, T. H. Yang, Y. W. Chang, C. Y.; Wu, Y. H. Sun, W. C.; Yu, M. S.; Lee, C. Y.; Lo, Y. H. Dalton Trans. 2011, 40, 12663-12666. (d) Pettinari, C.; Marchetti, F.; Cerquetella, A.; Pettinari, R.; Monari, M.; Mac Leod, T. C. O.; Martins, L. M. D. R. S.; Pombeiro, A. J. L. Organometallics, 2011, 30, 1616-1626. (e) Cheung, H. W.; So, C. M.; Pun, K. H.; Zhou, Z. Y.; Lau, C. P. Adv. Synth. Cat. 2011, 353, 411-425. (f) Lee, T. Y.; Dang, L.; Zhou, Z. Y.; Yeung, C. H.; Lin, Z. Y.; Lau, C. P. Eur. J. Inorg. Chem. 2010, 5675-5684. (g) Foley, N. A.; Lee, J. P.; Ke, Z.; Gunnoe, T. B.; Cundari, T. R. Acc. Chem. Res. 2009, 42, 585-597. (h) Díaz-Requejo, M. M.; Pérez, P. J. Chem. Rev. 2008, 108, 3379-3394.

(11) Smith, J. M. Comments Inorg. Chem. 2008, 29, 189-233.

(12) (a) Saouma, C. T.; Lu, C. C.; Peters, J. C. Inorg. Chem. 2012, 51, 10043-10054. (b) Fuentes, M. A.; Álvarez, E.; Caballero, A.; Pérez, P. J. Organometallics 2012, 31, 959-965. (c , J. A.; Ciriano, M. A. Organometallics 2012, 31, 2895-2906. (d) Tejel, C.; Ciriano, M. A; Passarelli, V. Chem. Eur. J. 2011, 17, 91-95. (e) Saouma, C. T.; Moore, C. E.; Rheingold, A. R.; Peters, J. C. Inorg. Chem. 2011, 50, 1128511287. (f) Lipke, M. C.; Tilley, T. D. J. Am. Chem. Soc. 2011, 133, 16374-16377. (g) Stradiotto, M.; Hesp, K. D.; Lundgren, R. J. Angew. Chem. Int. Ed. 2010, 49, 494-512 (h) Mehn, M. P.; Peters, J. C. J. Inorg. Biochem. 2006, 100, 634-643. (i) Jenkins, D. M.; Peters, J. C. J. Am. Chem. Soc. 2005, 127, 7148-7165. (j) Turculet, L.; Feldman, J. D.; Tilley, T. D. Organometallics 2004, 23, 2488-2502. (k) Betley, A. T.; Peters, J. C. Inorg. Chem. 2003, 42, 
5074-5084. (1) Turculet, L.; Feldman, J. D.; Tilley, T. D. Organometallics 2003, 22, 4627-4629.

(m) Barney, A. A.; Heyduk, A. F.; Nocera, D. G. Chem. Commun. 1999, 2379-2380.

(13) (a) Riordan, C. G. Coord. Chem. Rev. 2010, 254, 1815-1825. (b) Crossley, I. R.; Hill, A. F.; Willis, A. C. Organometallics 2010, 29, 326-336. (c) Mock, M. T.; Kieber-Emmons, M. T.; Popescu, C. V.; Gasda, P.; Yap, G. P. A.; Riordan, C. G. Inorg. Chim. Acta 2009, 362, 45534562. (d) Popescu, C. V.; Mock, M. T.; Stoian, S. A.; Dougherty, W. G.; Yap, G. P. A.; Riordan, C. G. Inorg. Chem. 2009, 48, 8317-8324. (e) Spicer, M. D.; Reglinski, J. Eur. J. Inorg. Chem. 2009, 1553-1574. (f) Mock, M. T.; Popescu, C. V.; Yap, G. P. A.; Dougherty, W. G.; Riordan, C. G. Inorg. Chem. 2008, 47, 1889-1891. (g) DuPont, J. A.; Yap, G. P. A.; Riordan, C. G. Inorg. Chem. 2008, 47, 10700-10707. (h) Ge, P.; Haggerty, B. S.; Rheingold, A. L.; Riordan, C. G J. Am. Chem. Soc. 1994, 116, 8406-8407.

(14) (a) Chen, F.; Wang, G. -F.; Li, Y. -Z.; Chen, X. -T.; Xue, Z. -L. Inorg. Chem. Commun. 2012, 21, 88-91. (b) Muñoz, S. B.; Foster, W. K.; Lin, H. -J.; Margarit, C. G.; Dickie, D. A. Inorg. Chem. 2012, 51, 12660-12668. (c) Mata, J. A.; Poyatos, M.; Peris, E. Coord. Chem. Rev. 2007, 251, 841-859.

(15) (a) Smith, J. M.; Mayberry, D. E.; Margarit, C. G.; Sutter, J.; Wang, H.; Meyer, K.; Bontchev, R. P. J. Am. Chem. Soc. 2012, 134, 6516-6519. (b) Kinney, R. A.; Saouma, C. T.; Peters, J. C.; Hoffman, B. M. J. Am. Chem. Soc. 2012, 134, 12637-12647. (c) Owen, G. R. Chem. Soc. Rev. 2012, 41, 3535-3546. (d) Saouma, C. T.; Peters, J. C. Coord. Chem. Rev. 2011, 255, 920-937. (e) Scepaniak, J. J.; Vogel, C. S.; Khusniyarov, M. M.; Heinemann, F. W.; Meyer, K.; Smith, J. M. Science 2011, 331, 1049-1052. (f) Saouma, C. T.; Kinney, R. A.; Hoffman, B. M.; Peters, J. C. Angew. Chem. Int. Ed. 2011, 50, 3446-3449. (g) Scepaniak, J. J.; Bontchev, R. 
P.; Johnson, D. L.; Smith, J. M. Angew. Chem. Int. Ed. 2011, 50, 6630-6633. (h) Jiménez, S.; López, J. A.; Ciriano, M. A.; Tejel, C.; Martínez, A.; Sánchez-Delgado, R. Organometallics 2009, 28, 3193-3202 (i) Tejel, C.; Ciriano, M. A.; Jiménez, S.; Passarelli, V.; López, J. A. Angew. Chem. Int. Ed. 2008, 47, 2093-2096.

(16) Casado, M. A.; Hack, V.; Camerano, J. A.; Ciriano, M. A.; Tejel, C.; Oro, L. A. Inorg. Chem. 2005, 44, 9122-9124.

(17) Thomas, C. M.; Mankad, N. P.; Peters, J. C. J. Am. Chem. Soc. 2006, 128, 4956-4957.

(18) Camerano, J. A.; Casado, M. A.; Ciriano, M. A.; Tejel, C.; Oro, L. A. Chem. Eur. J. 2008, 14, 1897-1905.

(19) Northcutt, T. O.; Lachicotte, R. J.; Jones, W. D. Organometallics 1998, 17, 5148-5152.

(20) (a) Ruman, T.; Ciunik, Z.; Trzeciak, A. M.; Ziółkowski, J. J. Organometallics 2003, 22, 1072-1080. (b) Moszner, M.; Wołowiec, S.; Trösch, A.; Vahrenkamp, H. J. Organomet. Chem. 2000, 595, 178-185. (c) Bucher, U. E.; Currao, A.; Nesper, R.; Rüegger, H.; Venanzi, L. M.; Younger, E. Inorg. Chem. 1995, 34, 66-74. (d) Cocivera, M.; Desmond, T. J.; Ferguson, G.; Kaitner, B.; Lalor, F. J.; O’Sullivan, D. J. Organometallics 1982, 1, 1125-1132. (e) Cocivera, M.; Ferguson, G.; Kaitner, B.; Lalor, F. J.; O’Sullivan, D. J.; Parvez, M.; Ruhl, B. Organometallics 1982, 1, 1132-1139.

(21) Padilla-Martínez, I. I.; Poveda, M. L.; Carmona, E.; Monje, M. A.; Ruiz-Valero, C.; Organometallics 2002, 21, 93-104.

(22) Marcén, S.; Jiménez, M. V.; Dobrinovich, I. T.; Lahoz, F. J.; Oro, L. A. Organometallics 2002, 21, 326-330 
(23) Tejel, C.; Villoro, J. M.; Ciriano, M. A.; López, J. A.; Eguizábal, E.; Lahoz, F. J.; Bakhmutov, V. I.; Oro, L. A. Organometallics 1996, 15, 2967-2978.

(24) Jones, W. D.; Hessell, E. T. Inorg. Chem. 1991, 30, 778-783.

(25) Nicasio, M. C.; Paneque, M.; Pérez, P. J.; Pizzano, A.; Poveda, M. L.; Rey, L.; Sirol, S.; Taboada, S.; Trujillo, M.; Monge, A.; Ruiz, C.; Carmona, E. Inorg. Chem. 2000, 39, 180-188

(26) Ball, R. G.; Ghosh, C. K.; Hoyano, J. K.; McMaster, A. D.; Graham, W. A. G. J. Chem. Soc., Chem. Commun. 1989, 341- 342.

(27) Elliott, P. I. P.; Haslam, C. E.; Spey, S. E.; Haynes, A. Inorg. Chem. 2006, 45, $6269-6275$.

(28) Hartwig, J. Organotransition metal chemistry; University Science Books: Sausalito, California, 2010.

(29) Mitoraj, M.; Michalak, A. Organometallics 2007, 26, 6576-6580.

(30) (a) Böttcher, H.-C.; Graf, M.; Karaghiosoff, K.; Mayer, P. Z. Anorg. Allg. Chem. 2007, 633, 2374-2379 (X = Cl, L = ${ }^{t} \mathrm{Bu}_{2} \mathrm{PH}, 2.104(3) \AA ̊$ ). (b) Gil-Rubio, J.; Weberndörfer, B.; Werner, H. J. Chem. Soc., Dalton Trans. 1999, 1437-1444 (X = F, L $={ }^{i} \operatorname{Pr}_{3} \mathrm{P}, 2.099(5) \AA \AA$ in av.). (c) Selent, D.; Scharfenberg-Pfeiffer, D.; Reck, G.; Taube, R. J. Organomet. Chem. 1991, 415, 417$423\left(\mathrm{X}=\mathrm{Cl}, \mathrm{L}=\mathrm{C}_{5} \mathrm{H}_{10} \mathrm{NH}, 2.065 \AA\right.$ in av.). (d) Busetto, C.; D'Alfonso, A.; Maspero, F.; Perego, G.; Zazzetta, A. J. Chem. Soc., Dalton Trans. 1977, 1828-1834 (X $=\mathrm{Cl}, \mathrm{L}={ }^{i} \operatorname{Pr}_{3} \mathrm{P}, 2.122(2) \AA$ in av.). 
(31) (a) Willems, S. T. H.; Russcher,J. C.; Budzelaar, P. H. M.; de Bruin, B.; de Gelder, R.; Smits, J. M. M.; Gal, A. W. Chem. Commun. 2002, 148-149 $\left(\mathrm{L}_{2}=\right.$ bisoxazolinate, $2.127(9) \AA$ in av.). (b) Bühl, M.; Håkansson, M.; Mahmoudkhani, A. H.; Öhrström, L. Organometallics 2000, 19, 5589-5596 ( $\mathrm{L}_{2}=$ 2,4-pentanedionato, 2.127(5) $\AA$; 1,1,1,5,5,5-hexafluoro-2,4-pentanedionato, 2.121(3) Å). (c) Budzelaar, P. H. M.; Moonen, N. N. P.; de Gelder, R.; Smits, J. M. M.; Gal, A. W. Eur. J. Inorg. Chem. 2000, 753-769 (L $\mathrm{L}_{2}=\beta$-diiminate, 2.145(4) Å in av.). (d) Baena, M. J.; Reyes, M. L.; Rey, L.; Carmona, E.; Nicasio, M. C.; Pérez, P. J.; Gutierréz, E.; Monge, A. Inorg. Chim. Acta 1998, 273, 244-254 ( $\mathrm{L}_{2}=\mathrm{H}_{2} \mathrm{~B}\left(3,5-\mathrm{Me}_{2} \mathrm{Pz}\right)_{2}, 2.122(5) \AA$ in av.).

(32) (a) Rubio, M.; Suárez, A.; Vega, E.; Álvarez, E.; Díez, J.; Gamasa, M. P.; Pizzano, A. Eur. J. Inorg. Chem. 2012, 655-633 (n = 1, 2.221(6) Å in av.). (b) Rubio, M.; Suárez, A.; del Río, D.; Galindo, A.; Álvarez, E.; Pizzano, A. Organometallics 2009, 28, 547-560 (n = 0, 2.229(3) Å in av.). (c) Rubio, M.; Suárez, A.; del Río, D.; Galindo, A.; Álvarez, E.; Pizzano, A. Dalton Trans. 2007, 407- 409 ( $\mathrm{n}=0$, 2.227(1) $\AA$ in av.). (d) Hahn, C.; Sieler, J.; Taube, R. Chem. Ber. 1997, 130, 939-945 ( $\mathrm{n}=1,2.149 \AA$ in av.).

(33) Angular dependence for the ${ }^{2} J_{\mathrm{P}, \mathrm{P}}$ coupling constants and the $\mathrm{P}-\mathrm{M}-\mathrm{P}$ angle can be considered from the well-known strong difference between ${ }^{2} J_{\mathrm{P}, \mathrm{P}}(\operatorname{trans})$ (around $180^{\circ}$ ) and ${ }^{2} J_{\mathrm{P}, \mathrm{P}}(\mathrm{cis})\left(\right.$ around $90^{\circ}$ ): (a) Kühl, O. Phosphoros-31NMR spectroscopy, Springer-Verlag Berlin Heidelberg, 2008 (p. 22). (b) Casey, C. P.; Paulsen, E. L.; Beuttenmueller, E. W. Proft, B. R.; Petrovich, L. M.; Matter, B. A.; Powell, D. R. J. Am. Chem. Soc. 1997, 119, 11817-11825. (c) Gull A. M.; Fanwick P. E.; Kubiak C. P. Organometallics, 1993, 12, 2121-2125.

(34) Selected examples for complexes of the type [ $\operatorname{IrR}($ olefin $\left.)\left(\mathrm{PMe}_{3}\right)_{3}\right]$ : (a) Bleeke J. R.; Thananatthanachon T.; Rath N. P. Organometallics, 2007, 26, 3904-3907 $\left({ }^{2} J_{\mathrm{P}, \mathrm{P}}=45.8,25.6\right.$, 
22.8 Hz). (b) Bleeke J. R.; Ortwerth M. F.; Chiang M. Y. Organometallics, 1992, 11, 2740-2743 $\left({ }^{2} J_{\mathrm{P}, \mathrm{P}}=42.3,17.6,16.0 \mathrm{~Hz}\right)$. (c) Bleeke, J. R.; Boorsma, D.; Chiang, M. Y.; Clayton, Jr. T. W.; Haile, T.; Beatty, A. M.; Xie, Y.-F. Organometallics 1991, 10, 2391-2398 $\left({ }^{2} J_{\mathrm{P}, \mathrm{P}}=41.8,18.3\right.$ Hz). (d) Merola J. S.; Kacmarcik R. T. Organometallics, 1989, 8, 778-784 $\left({ }^{2} J_{\mathrm{P}, \mathrm{P}}=52.0,12.9\right.$, 10.5 Hz). [IrR(CO)(olefin) $\left.\left(\mathrm{PPh}_{3}\right)_{2}\right]$, (e) Ionkin A. S.; Marshall W. J. Inorg. Chem. 2005, 44, 6244-6247 ( $\left.{ }^{2} J_{\mathrm{Peq}, \text { Peq }}=55.3 \mathrm{~Hz}\right)$. (f) Nishihara Y.; Yoda C.; Osakada K. Organometallics, 2001, $20,2124-2126\left({ }^{2} J_{\text {Peq,Peq }}=43.4 \mathrm{~Hz}\right)$.

(35) (a) Goldberg, S. Z.; Eisenberg, R. Inorg. Chem. 1976, 15, 58-63. (b) Rossi, A. R.; Hoffmann, R. Inorg. Chem. 1975, 14, 365-374.

(36) See for example: (a) Kirchmann, M.; Fleischhauer, S.; Wesemann, L. Organometallics 2008, 27, 2803-2808 ([Me $\left.\mathrm{N}]\left[\operatorname{Ir}\left(\mathrm{SnB}_{11} \mathrm{H}_{11}\right)(\mathrm{CO})\left(\mathrm{C}_{2} \mathrm{H}_{4}\right)\left(\mathrm{PPh}_{3}\right)_{2}\right], v(\mathrm{CO}) \mathrm{eq}=1942 \mathrm{~cm}^{-1}\right)$. (b) Itazaki, M.; Yoda, C.; Nishihara, Y.; Osakada, K. Organometallics 2004, 23, 5402-5409 $\left(\left[\operatorname{Ir}\left(\eta^{1}: \eta^{2}-\mathrm{CH}_{2} \mathrm{C}\left(\mathrm{CH}_{2} \mathrm{CH}_{2} \mathrm{Ph}\right)_{2} \mathrm{CH}=\mathrm{CH} 2\right)(\mathrm{CO})\left(\mathrm{PPh}_{3}\right)_{2}\right], \quad v(\mathrm{CO})\right.$ eq $\left.=1941 \mathrm{~cm}^{-1}\right)$. (c) Brian $\mathrm{P}$. Cleary, B. P.; Eisenberg, R. J. Am. Chem. Soc. 1995, 117, 3510-3521; ibid Organometallics 1992, 11, 2336-2337 ([ $\left.\left.\operatorname{Ir}\left(\mathrm{CH}_{2} \mathrm{C}_{6} \mathrm{H}_{3} \mathrm{Me}_{2}\right)(\mathrm{CO})\left(\mathrm{C}_{2} \mathrm{H}_{4}\right)(\mathrm{dppe})\right], v(\mathrm{CO}) \mathrm{eq}=1955 \mathrm{~cm}^{-1}\right)$. (d) Li, R. T.; Nguyen, S. T.; Grubbs, R. H.; Ziller, J. W. J. Am. Chem. Soc. 1994, 116, 10032-10040 ([Ir(Cl) $\left(\eta^{2}\right.$-3,3-diphenylcyclopropene $\left.)(\mathrm{CO})\left(\mathrm{PR}_{3}\right)_{2}\right], v(\mathrm{CO}) \mathrm{ax}=1986\left(\mathrm{PMe}_{3}\right), 1993\left(\mathrm{PMe}_{2} \mathrm{Ph}\right), 2001$ $\left.\left(\mathrm{PMePh}_{2}\right), 1979\left(\mathrm{PEt}_{3}\right) \mathrm{cm}^{-1}\right)$. (e) Balch, A. L.; Catalano; V. J.; Lee, J. W. Inorg. Chem. 1991, 30, 3980-3981 $\left(\left[\mathrm{Ir}(\mathrm{Cl})\left(\eta^{2}-\mathrm{C}_{60}\right)(\mathrm{CO})\left(\mathrm{PPh}_{3}\right)_{2}\right], v(\mathrm{CO}) \mathrm{ax}=2014 \mathrm{~cm}^{-1}\right)$. (f) Deutsch, P. P.; Eisenberg, R. J. Am. Chem. Soc. 1990, 112, 714-721 ([Ir $\left.\left(\sigma-\mathrm{C}_{2} \mathrm{H}_{5}\right)\left(\mathrm{C}_{2} \mathrm{H}_{4}\right)(\mathrm{CO})(\mathrm{dppe})\right], v(\mathrm{CO})$ eq $\left.=1938,1893 \mathrm{~cm}^{-1}\right)$. (g) Baddley, W.H.; Fraser, M. S. J. Am. Chem. Soc. 1969, 91, 3661-3663 $\left(\left[\operatorname{Ir}\left(\sigma-\mathrm{CH}_{2} \mathrm{CH}_{2} \mathrm{CN}\right)(\mathrm{CNCH}=\mathrm{CHCN})(\mathrm{CO})\left(\mathrm{PPh}_{3}\right)_{2}\right], v(\mathrm{CO}) \mathrm{ax}=2035 \mathrm{~cm}^{-1}\right)$. 
(37) See for example: (a) Gutiérrez-Puebla, E.; Monge, A.; Nicasio, M. C.; Pérez, P. J.; Poveda, M. L.; Rey, L.; Ruiz, C.; Carmona, E. Inorg. Chem. 1998, 37, 4538-4546 ([ $\operatorname{Ir}\left(\kappa^{3}-3,5-\right.$ $\left.\left.\left.\mathrm{Me}_{2} \mathrm{Tp}\right)\left(\mathrm{C}_{2} \mathrm{H}_{4}\right)(\mathrm{CO})\right], v(\mathrm{CO}) \mathrm{ax}=1990 \mathrm{~cm}^{-1}\right)$. (b) Stössel, P.; Heins, W.; Mayer, H. A.; Fawzi, R.; Steimann, M. Organometallics 1996, 15, 3393-3403 $\left(\left[\operatorname{Ir}\left(\kappa^{3}-\mathrm{P}_{3}\right)\left(\mathrm{C}_{2} \mathrm{H}_{4}\right)(\mathrm{CO})\right]^{+}, v(\mathrm{CO}) \mathrm{ax}=2025\right.$ (tdppcy), 2055 (tdppcycn), 2043 (tdppcyme) $\mathrm{cm}^{-1}$ ). (c) Jenkins, H. A.; Loeb, S. J. Organometallics 1994, 13, 1840-1850 $\left(\left[\operatorname{Ir}\left(\kappa^{3}-\mathrm{S}_{3}\right)\left(\mathrm{C}_{8} \mathrm{H}_{14}\right)(\mathrm{CO})\right]^{+}, v(\mathrm{CO}) \mathrm{ax}=2073 \mathrm{~cm}^{-1}\right.$. (d) Ciriano, M. A., Férnandez, M. J.; Modrego, J.; Rodriguez, M. J.; Oro, L. A. J. Organomet. Chem. 1993, 443, 249-252 ([Ir( $\left.\left.\left(\kappa^{3}-\mathrm{Tp}\right)\left(\mathrm{C}_{2} \mathrm{H}_{4}\right)(\mathrm{CO})\right], v(\mathrm{CO}) \mathrm{ax}=2000 \mathrm{~cm}^{-1}\right)$. (e) Perera, S. D.; Shaw, B. L. J. Chem. Soc., Chem. Commun. 1995, 865-866 $\left(\left[\operatorname{Ir}\left(\kappa^{3}-\mathrm{P}_{2} \mathrm{~N}\right)\left(\mathrm{C}_{2} \mathrm{H}_{4}\right)(\mathrm{CO})\right], v(\mathrm{CO}) \mathrm{ax}=\right.$ $\left.2015 \mathrm{~cm}^{-1}\right)$.

(38) Tejel, C.; Ciriano, M. A.; Millaruelo, M.; López, J. A.; Lahoz, F. J.; Oro, L. A. Inorg. Chem. 2003, 42, 4750-4758.

(39) Rappoli, B. J.; Churchill, M. R.; Janik, T. S.; Rees, W. M.; Atwood, J. D. J. Am. Chem. Soc. 1987, 109, 5145-5149.

(40) Rees, W. M.; Churchill, M. R.; Fettinger, J. C.; Atwood, J. D. J. Organomet. Chem. 1986, $319,411-422$.

(41) Paneque, M.; Posadas, C. M.; Poveda, M. L.; Rendón, N.; Mereiter, K. Organometallics 2007, 26, 3120-3129.

(42) Perrin, D. D. W.; Armarego, L. F. Purification of Laboratory Chemicals, 3rd ed., Pergamon Press, Exeter, UK 1988.

(43) Giordano, G.; Crabtree, R. H. Inorg. Synth. 1990, 28, 88-90. 
(44) Crabtree, R. H., Morris, G. E. J. Organomet. Chem. 1977, 135, 395-403.

(45) Ir(acac)(cod) Robinson, S. R.; Shaw, B. L. J. Chem. Soc. 1965, 4997-5001.

(46) Fraenkel, G.; Winchester, W. R.; Williard, P. G. Organometallics 1989, 8, 2308-2311.

(47) Wagner, C. E.; Kim, J.-S.; Shea, K. J. J. Am. Chem. Soc. 2003, 125, 12179-12195.

(48) (a) Becke, A. D. Phys. Rev. A, 1988, 38, 3098-3100. (b) Lee, C.; Yang, W.; Parr, R. G. Phys. Rev. B, 1988, 37, 785-789. (c) Becke, A. D. J. Chem. Phys. 1993, 98, 5648-5652.

(49) Gaussian 09, Revision A.02, Frisch, M. J., Trucks, G. W., Schlegel, H. B., Scuseria, G. E., Robb, M. A., Cheeseman, J. R., Scalmani, G., Barone, V., Mennucci, B., Petersson, G. A., Nakatsuji, H., Caricato, M., Li, X., Hratchian, H. P., Izmaylov, A. F., Bloino, J., Zheng, G., Sonnenberg, J. L., Hada, M., Ehara, M., Toyota, K., Fukuda, R., Hasegawa, J., Ishida, M., Nakajima, T., Honda, Y., Kitao, O., Nakai, H., Vreven, T., Montgomery, Jr., J. A., Peralta, J. E., Ogliaro, F., Bearpark, M., Heyd, J. J., Brothers, E., Kudin, K. N., Staroverov, V. N., Kobayashi, R., Normand, J., Raghavachari, K., Rendell, A., Burant, J. C. Iyengar, S. S. Tomasi, J. Cossi, M. Rega, Millam, N. J., Klene, M. Knox, J. E., Cross, J. B., Bakken, V., Adamo, C., Jaramillo, J., Gomperts, R. E. Stratmann, O. Yazyev, A. J. Austin, R. Cammi, C. Pomelli, J. W. Ochterski, R. Martin, R. L., Morokuma, K., Zakrzewski, V. G., Voth, G. A., Salvador, P., Dannenberg, J. J., Dapprich, S., Daniels, A. D., Farkas, O., Foresman, J. B., Ortiz, J. V., Cioslowski, J., and Fox, D. J., Gian, Inc., Wallingford CT, 2009.

(50) Sheldrick, G. M. SADABS, Bruker AXS, Madison, WI (USA), 1997.

(51) Sheldrick, G. M. Acta Cryst. 2008, A64, 112-122. 
(52) Farrugia, L. F. J. Appl. Crystallogr. 1999, 32, 837-838.

For Table of Contents Only

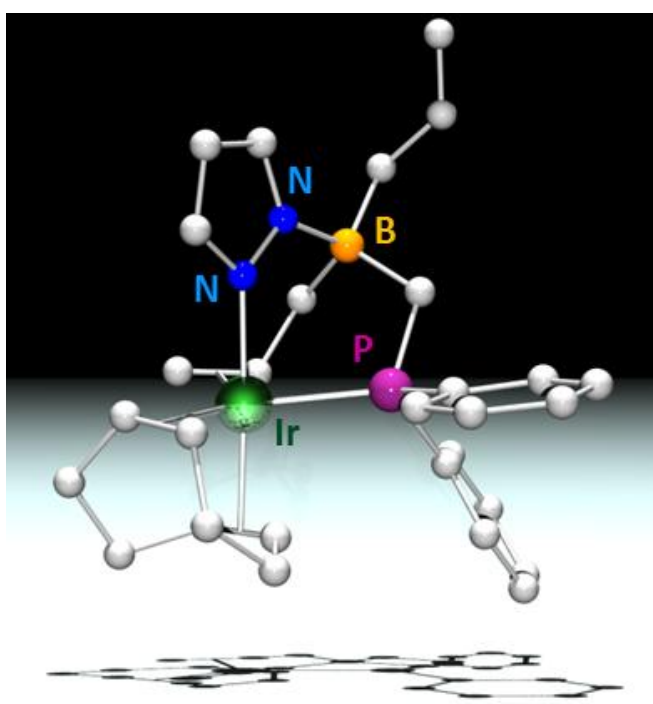

